\title{
Del suicidio de Judas al salto de Pármeno: codicia, traición y caídas mortales en La Celestina ${ }^{1}$
}

\author{
Rafael Beltrán \\ Universitat de València
}

\section{RESUMEN}

El artículo se propone el estudio de las influencias de los motivos de la traición y suicidio de Judas Iscariote en las caídas mortales de cuatro personajes principales de La Celestina. Judas encarna, mejor que ningún otro personaje bíblico, la trayectoria del pecador, desde la lealtad y la traición hasta la desesperación y la muerte suicida. Se examina la figura literaria e iconográfica de la codicia, traición y suicidio de Judas en la Edad Media, centrándonos en los dos tipos de suicidio que refleja la Biblia. Se analizan las caídas accidentales (Calisto), los saltos mortales al vacío (Sempronio y Pármeno) y el suicidio (Melibea); las imágenes de representación de la traición (la bolsa de las monedas); y, finalmente, la trayectoria de Pármeno, que va, como la de Judas, desde fidelidad del buen criado, pasando por la codicia y la traición, hasta el salto mortal hacia el vacío desesperado.

Palabras Clave: La Celestina, Judas, Pármeno, suicidio, traición, caídas mortales.

\section{From Judas' suicide to Pármeno's jump: avarice, betrayal and mortal falls in La Celestina}

ABSTRACT

The article aims to study the influence of Judas Iscariot's motifs of betrayal and suicide on the mortal falls of four main characters in La Celestina. Judas embodies, better than any other biblical character, the sinner's progress from loyalty and betrayal to despair and suicidal death. The literary and iconographic figures of the greed, the betrayal and the suicide of Judas in the Middle Ages are examined, focusing on the two types of suicide reflected in the Bible. Accidental falls (Calisto), fatal leaps (Sempronio and Pármeno) and suicide (Melibea) are analysed, together with the images representing the betrayal (the bag of coins). Finally, Pármeno's life, similarly to that of Judas, is studied since it goes from the fidelity of the good servant, through greed and betrayal, to a mortal jump into the void.

KeY Words: La Celestina, Judas, Pármeno, suicide, betrayal, mortal jumps.

1.- Este artículo forma parte del proyecto de investigación FFI2017-82588-P (AEI/FEDER, UE), concedido por el Ministerio de Economía, Industria y Competitividad. Agradezco a Óscar Calvé la lectura, sus valiosos comentarios y la aportación de documentos gráficos al artículo. 
A José Luis Canet, amigo de siempre y para siempre

\section{Preámbulo: la sombra de Judas}

« Saltemos destas ventanas, no muramos en poder de justicia!», le grita Sempronio a Pármeno, tras haber asesinado a Celestina, desesperado al comprobar que no pueden escapar por la puerta de la casa, tomada por la guardia del alguacil. «Salta, que yo tras ti voy», le contesta Pármeno. ${ }^{2}$ Así concluye el auto xII. Sempronio salta y no sólo se descoyunta en la caída desde la ventana, sino que queda medio muerto. Más tarde saltará Pármeno, con igual resultado, como sabremos luego por los relatos de Sosia (XIII, 266-267) y de Elicia (XV, 289), quienes coinciden en que «saltaron de las ventanas» ("de unas ventanas muy altas», aclara Sosia) y "cuasi muertos les cortaron las cabezas, que creo que ya no sintieron nada» (Sosia) o "cuasi muertos los prendieron y sin más dilación los degollaron» (Elicia). La secuencia la reflejan los grabados de las primeras ediciones de $\mathrm{La} \mathrm{Ce}$ lestina (Fig. 1 y Fig. 2), ${ }^{3}$ con una sola composición que en principio agrupa en dos planos yuxtapuestos la escena del asesinato y la del salto; en esta segunda escena, a su vez, se solapan dos tiempos: Sempronio se encuentra ya en el suelo, tras haber saltado, mientras que Pármeno salta al vacío desde una ventana de la casa, que en la imagen no puede aparecer como «muy alta» —como decía Sosia que era- por necesidades de proporción $\mathrm{y}$ ajuste entre personajes y espacios en el grabado.

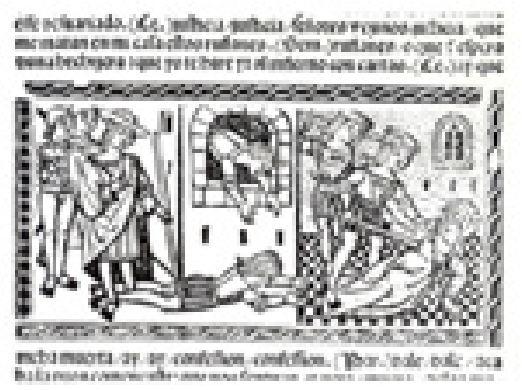

Fig. 1. Salto de Pármeno y asesinato de Celestina (Valencia, 1514)

2.- Citaré siempre por la edición coordinada por Rico (2011). Teniendo presentes, además, las lecturas y notas de las ediciones de Comedia y Tragicomedia editadas por José Luis Canet: $<$ https://parnaseo.uv.es/Celestinesca/Anejos.html>.

3.- Fig. 1: Tipobibliografía valenciana de los siglos XV y XVI, base de datos dirigida por José Luis Canet: <https://parnaseo.uv.es/imprenta/imagenes/Imgs/123_Grabados_grabado-14.jpg>. Fig. 2: ¿Cromberger? e ilustrador anónimo, «Ilustración primera del acto XIII de la edición de Roma: Marcelo Silber, 1515 (colofón Stanislao Polono, Sevilla, 1502)», en CelestinaVisual.org, consulta 4 de septiembre de 2020, <http://celestinavisual.org/items/show/453>. 


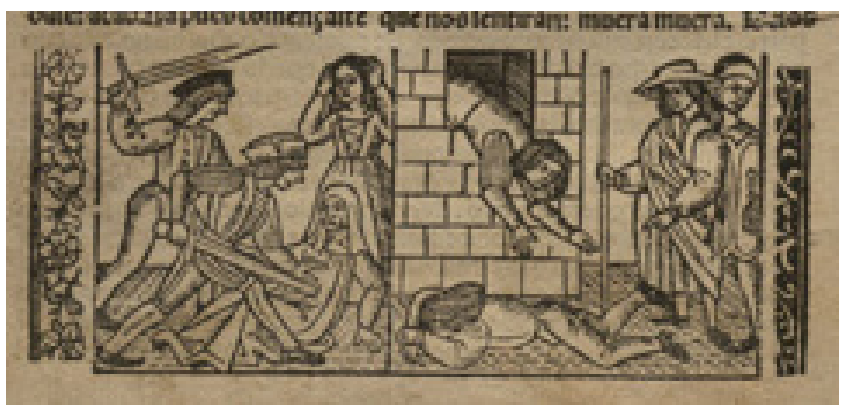

Fig. 2. Asesinato de Celestina y salto de Pármeno (Sevilla, 1518-1520 [1502])

Pármeno, Sempronio, Calisto y Melibea, de muy dispares maneras y por distintas razones, participan en unas peligrosas acrobacias de fatídicos vuelos, accidentales o suicidas, con desenlaces siempre letales. Son cuatro de los cinco personajes que mueren in prosentia en el curso de la Comedia y, luego, de la Tragicomedia (todos menos el quinto, Celestina). De un sexto personaje, Claudina, se menciona la muerte en el pasado (in absentia). Hay escasos precedentes literarios para justificar estos y otros saltos o caídas mortales: los vuelos de Ícaro o Faetón, los suicidios de Hero o Dido, más algunos otros que iremos desgranando. Pero pienso que no se le ha prestado suficiente atención, en este contexto, a otro referente que, sin embargo, podría ser importante a la hora de establecer relaciones con la tradición literaria de todo ese conjunto de muertes traumáticas, de muertes que sellan con su subrayado enfático la consumación de comportamientos siempre censurables y punibles. Porque, sin duda, la muerte de Judas Iscariote, en una de las dos versiones canónicas evangélicas conservadas, es otro salto mortal, con el que él mismo castiga su propia carrera de pecados imperdonables: "[Judas] cayó de cabeza, reventó por medio y se esparcieron todas sus entrañas» (Hechos, 1: 18). De haber sido Judas un personaje secundario, anecdótico, sin mayor trascendencia, no daríamos mayor importancia a ese final desastroso. Pero tratándose de quien ha sido para el cristianismo el Traidor por antonomasia, merece la pena que nos detengamos en su posible relación con el texto de Rojas.

No ha recabado apenas atención entre los estudiosos de La Celestina la más que plausible influencia ni de ese desenlace, ni de la trayectoria anterior de Judas, leal servidor de su señor primero, codicioso y traidor hasta la muerte después. Y ello, a pesar de la innegable preeminencia de su imagen en la historia y en la simbología del cristianismo, y a pesar de su popularidad — negativa, por descontado- dentro de la mitología cristiana. Sin embargo, su itinerario (codicia $\rightarrow$ traición $\rightarrow$ muerte) se dibuja esquemáticamente como paralelo, casi igual, al de Sempronio y, sobre 
todo, al de Pármeno, quien había sido más leal y, por tanto, incluso más censurablemente traidor a Calisto que su compinche.

Seguramente no ha atraído esa mínima curiosidad, porque el personaje y el mismo antropónimo, "Judas», se ciernen sobre la cultura del cristianismo como sombras más que como presencias, como un silencio más que como una voz. Hay sombras y silencios que esconden miedos a lo ominoso o tratan de censurar lo execrable, de conjurar lo abominable. $Y$ parece indudable que se oculta $-\mathrm{O}$ se hace inefable - su nombre en medio del florido vergel de léxico y de referentes de La Celestina. Sin embargo, esa elipsis o supresión tampoco es rara, sino bastante habitual en el Medievo, y ese silencio sepulcral puede llegar a resultar de algún modo - sin paradojas - incluso un taceat elocuente en casos como éste. Lo cierto es que, aun tratándose, junto con Caín, Herodes o Nerón, de uno de los grandes perversos y de los traidores con mayor protagonismo en la literatura, en las artes figurativas (pintura, escultura, grabados, tapices) y en las manifestaciones teatrales o espectaculares de la Edad Media, el personaje de Judas ha sido muy pocas veces sacado a colación o tenido en cuenta a la hora de interpretar la obra de Fernando de Rojas. A mi juicio, en fin, su sombra se proyecta de forma más alargada y densa sobre $\mathrm{La}$ Celestina de lo que hasta ahora se ha hecho notar. ${ }^{4}$

Se ha apuntado, sí, a la impronta de su leyenda e imagen en un objeto determinado, como es la bolsa de Celestina, símbolo de su codicia, una «faltriquera» (I, 104) que hereda probablemente del atributo por excelencia de Judas en la iconografía medieval; pero se trata de un detalle de la vestimenta de la medianera que en el texto no tiene especial relevancia, aunque es cierto que resultará recurrente y llamativo en los grabados de la edición de Fadrique de Basilea, de Burgos (1499 [pero ca. 1501]), siendo posteriormente sustituido por el complemento colgante del rosario. ${ }^{5} \mathrm{Se}$ ha detectado y señalado asimismo - sin ir más allá de esa constatación fehaciente- la huella de la leyenda de Judas en un sintagma concreto, el de las «más de treinta estocadas» con las que dice Sosia que "la vi llagada [a Celestina], tendida en su casa» (XIII, 267), que remite de manera diáfana a las treinta monedas o piezas de plata con que se le paga al discípulo falso la traición a Jesús (Mateo, 26, 15). ${ }^{6}$ Beso de traición y espada alzada

4.- Solamente tres estudiosos recientes, que yo conozca, han aludido directamente a Judas en relación con la Tragicomedia, relacionándolo con la bolsa de monedas de Celestina (Fernández Rivera, 2013) o con el suicidio de Melibea (López-Ríos, 2005; Álvarez, 2017).

5.- Fernández, Rivera (2013) estudia muy bien esa presencia de la bolsa, como veremos. No indicaré, en adelante, más que la fecha de Burgos (1499), aun a sabiendas de que está puesta en duda la autenticidad de tal datación y que actualmente se postula una fecha posterior (ca. 1501-1502) para el incunable burgalés (véase, para un balance de las posturas al respecto, Canet, 1999, 2016).

6.- El número de «treinta», según los comentaristas bíblicos, no tiene valor concreto, sino simbólico. Se trata de una referencia a Zacarías 11,12-13: «Y les dije: 'Si os parece bien, dadme mi salario; y si no, dejadlo'. Y pesaron por mi salario treinta piezas de plata. Y me dijo Jeho- 
como reacción, es decir monedas (treinta) y estocadas («más de treinta») van parejas en casi todas las imágenes medievales del Prendimiento de Jesús — desde Giotto hasta Fra Angélico, pasando por la mayoría de testimonios gráficos que reflejan la escena-, cuando otro discípulo corta la oreja a un criado del Sumo sacerdote (el discípulo se identificará con Pedro, pero sólo en la versión evangélica de Juan).7 Sin embargo, me parece que, además de estos dos detalles, significativos pero menores, muy expresivos y representativos pero puntuales, se debe considerar y valorar mejor hasta qué punto la sombra de Judas cubre con su lobreguez aspectos más sustanciales de los recorridos de los personajes principales de la obra. En especial, aspectos vinculados con el radical cambio, condicionado por la codicia, que experimentan algunos de ellos - Celestina y los criados-y la justicia poética de sus finales, tan incomprensibles y desastrosos como los de los otros —Calisto y Melibea-, igualmente castigados en la obra con muertes atroces.

El texto de La Celestina, tal como es asimilado por sus primeros receptores - entre ellos, los impresores que incluyen sus primeros grabados- va perfilando a lo largo de sus autos centrales y decisivos una serie de contrafacta paródicos de la Pasión: la Visitatio (de Celestina a la casa de Melibea), la Última Cena (el auto Ix del banquete), el Prendimiento (Centurio y las figuras cobardes de los criados, que reniegan como san Pedro), el Descensus Christi (la omnipresente escala), etc. Pero en ese via crucis falta una escena esencial: la del beso de la traición, con Judas como protagonista.

Es muy posible que la ocultación o falta de alusión a Judas como probado codicioso, traidor y, sobre todo, suicida, es decir, su ausencia o alejamiento de la primera escena de las citas o referencias de muchas obras literarias, incluida La Celestina, tenga relación con el tejido ideológico urdido durante los últimos siglos de la Edad Media cristiana para intentar tapar o eliminar cualquier atisbo de consideración clásica del suicidio como opción honrosa (las muertes justificadas de Catón, Lucrecia, o incluso Dido), o cualquier barrunto de conexión entre el suicidio y el libre

vá: 'Échalo al tesoro; ¡hermoso precio con que me han apreciado!' Y tomé las treinta piezas de plata, y las eché en la casa de Jehová al tesoro». Lucrecia habla de los «treinta» oficios de Celestina. En realidad, Elicia se refiere por dos veces, cuando le cuenta los hechos a Areúsa, a que le dio «mil cuchilladas» (XV, 288 y 289).

7.- Lucas, 22, 47-51: «47 Estando todavía con la palabra en la boca, sobrevino un tropel de gente, delante de la cual iba uno de los doce, llamado Judas, que se arrimó á Jesus para besarle. 48 Y Jesus le dijo: ¡Oh Judas! ¿con un beso entregas al Hijo del hombre? 49 Viendo los que acompañaban á Jesus lo que iba á suceder, le dijeron: Señor, cheriremos con la espada? 50 Y uno de ellos hirió á un criado del príncipe de los sacerdotes, y le cortó la oreja derecha. 51 Pero Jesus tomando la palabra, dijo luego: Dejadlo, no paséis adelante. Y habiendo tocado la oreja del herido, le curó». Marcos 14,43-45 y Mateo 26, $47-49$ mencionan el detalle de la oreja cortada del criado. Y Juan 18,10-11, es el único que menciona a Simón Pedro, quien corta la oreja derecha a Malcho, criado del sacerdote. 
albedrío. ${ }^{8}$ La elección del suicidio como alternativa honorable para el ser humano, ente racional, se trató de ocultar, como si se tratara de un tabú inefable (en realidad, siempre lo ha sido de un modo u otro), hasta ser prácticamente eliminado como conjetura, experimentando un proceso de criminalización y abominación, que incluiría de manera muy patente la asociación con el mundo femenino. ${ }^{9}$ La utilización de la imagen de Judas formaba parte, como dice Álvarez cuando estudia lúcidamente el suicidio de Melibea, de un programa más amplio de abolición absoluta - damnatio memoriae - en la historia pasada o presente, de siquiera un ápice de dignidad o justificación para el suicidio:

...se cerró la vieja diferencia pagana entre suicidio heroico y la autodestrucción criminal que todavía late en Dante; se reforzó la relación iconográfica entre la causa del suicidio y su método; se explotó la imagen de Judas para criminalizar el acto o a la víctima; o se la demonizó y asoció a la locura usando el folclore (Brown 44, 53). Asimismo, se terminó de afianzar el vínculo entre las malas muertes y lo femenino, mediante el énfasis en la culpa, la debilidad de carácter (passio vs. ratio), la imperfección y la contaminación corporales. Este fue el caso de heroínas trágicas y mitológicas como Fedra, Jocasta, Hero o Dido, cuyos suicidios se fueron reduciendo solo a castigo o "precio" por pecados como el incesto o el deseo. (2017: 318)

Pármeno y Sempronio no se suicidan, sino que se arrojan por la ventana para huir, al no contar con otra posibilidad de escapatoria. Aparentemente, lo único que ocurre es que mueren como consecuencia lógica puesto que saltan desde lo alto. Pero moralmente la secuencia es la inversa: saltan para morir, porque saben que su crimen espantoso no tiene más salida que la muerte. Aunque estrictamente no sean suicidas, lo que les lleva a esos saltos precipitados, tras un crimen atroz y con un arrepentimiento tardío e inútil («iOh, pecador de mí...!», exclamará Pármeno, justo antes de tirarse), es una desesperación (desperatio) que arrastra tras sí, como una

8.- Lacarra (2007) estudia y describe la casuística de suicidios honorables (frente a reprobables) en la literatura española. Uno de los pocos justificados como honorables fue el de Catón, a quien Santillana cita favorablemente en su Bías contra Fortuna (estr. 122) y con más reparos en Proverbios (estr. 56). Pero Díaz de Toledo, Diálogo y razonamiento en la muerte del Marqués de Santillana refutará, en cambio, los argumentos presumiblemente favorables al suicidio digno por parte del poeta.

9.- Tanto Schmitt (1996) como Murray (2000) constatan que la condena general del suicidio fue realizada desde todas las instancias, incluidas las literarias, y que las excepciones fueron pocas. El suicidio se condena en el roman courtois, en la poesía y en el teatro, y en la épica se equipara siempre con el máximo fracaso y cobardía. 
condena bíblica, la de otros pecadores suicidas irredentos, y por encima de todos, en mi opinión, la sombra tenebrosa del más infame de todos: Judas.

\section{Traición, caída y suicidio de Judas}

\subsection{La figura literaria de Judas impio y desesperado}

Seguramente el perverso más prominente y conspicuo de toda la literatura bíblica (Antiguo y Nuevo Testamento) sea Judas Iscariote. La figura de Judas como quintaesencia del mal, impío por excelencia, fue diseñada, simplificada y cosificada por el cristianismo a partir de una secuencia narrativa trementadamente simple, eficaz y aleccionadora, combinada con imágenes mentales, literarias y gráficas muy poderosas, que en estado latente o muy rudimentario se encontraban ya en los textos de los Evangelios. De manera que una serie que viñetas relativamente sencillas $\mathrm{y}$ convencionales fueron encadendo elementos y objetos identificadores para él: los atributos delatores del pecado (la bolsa asociada a la avaricia, contenedora del pago de la traición), los de la imposible redención (la horca como indicio de la vía ciega del suicidio) y los del mayor castigo, el reservado a los infames (el cuerpo no cerrado y sepultado, sino permamentemente abierto - las entrañas dispersas - y expuesto a las alimañas y al oprobio). De ese modo se iba sustanciando en la memoria colectiva de la mitología cristiana el relato del camino hacia el Infierno del ser humano maligno, del servidor más ignominioso e impío, que no pudo ser ni podría haber sido jamás dignamente enterrado, tan enorme había sido la magnitud de su pecado. Judas se presentaba en las antípodas de la caritas de Cristo, desde su vida — que pudiendo haber sido tan pía como la de los otros discípulos, arruinó- hasta su muerte.

Una de las más tempranas representaciones que conservamos de Judas, lo expone en una Crucifixión junto a Jesús, casi con el mismo tamaño y relevancia visual que el Hijo de Dios, dando a entender que la ignominia de su pecado había sido equiparable a la magnitud de la bondad de Jesús (Fig. 3). Muertes en las antípodas, por tanto, pero mostradas insólitamente en paralelo, casi a un mismo nivel de relevancia, en una figuración radicalmente diferente de la de Jesús con los dos ladrones. Se trata de la placa lateral, de pequeñísimo tamaño $\left(10 \times 7^{\prime} 5 \mathrm{~cm}\right.$.), de una cajita de marfil realizada en Roma, entre los años 420 y 430. En ella observamos que la figura de Judas ahorcado ocupa tanto espacio como la de Cristo crucificado, planteando una doble alternativa, polarizada pero equilibrada, para la muerte del hombre: la buena y la mala muerte (Murray, 2000: 327). 


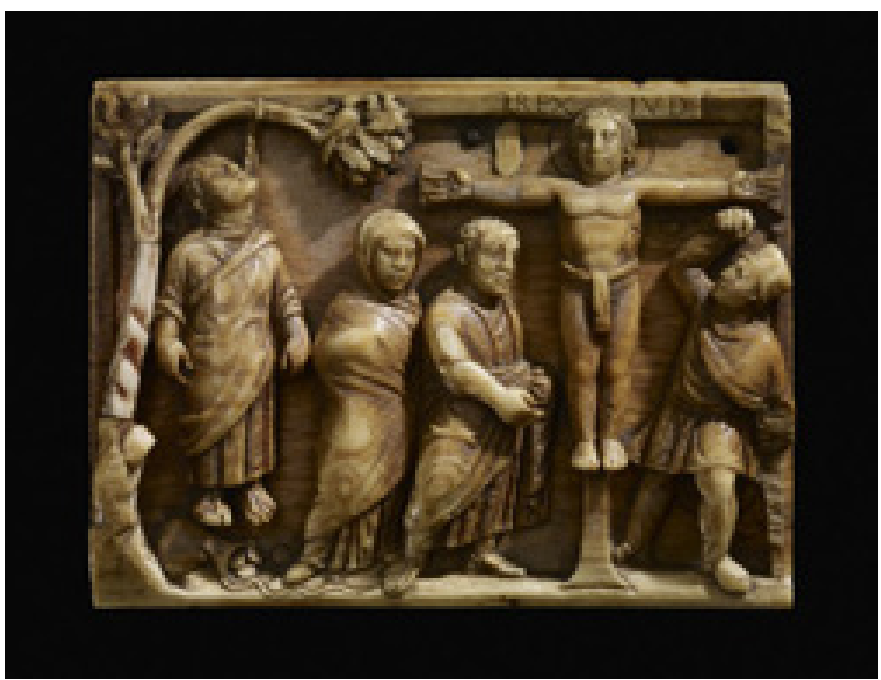

Fig. 3. Judas colgado, junto a Cristo crucificado.

Placa de marfil (c. 420-430). British Museum

Judas fue considerado en la Edad Media no sólo el Avaro por excelencia, sino también el Traidor por antonomasia, y los máximos traidores (traidores de lesa majestad) habían de sufrir la infamia de la muerte indigna -ahorcados, degollados o descuartizados-y la exposición pública de los despojos del cadáver. Dante Alighieri ya no es tan indulgente como el anónimo cincelador de la placa de marfil del siglo v y presenta Judas, en Judeca, la región más profunda del Infierno, en el canto XXXIV, devorado por Lucifer, junto a Bruto y Casio. Los tres tienen en común ser pecadores contra el gobierno o statu quo: nefandos traidores de alta traición. ${ }^{10}$

Arellano (2015) presenta una panorámica de la fortuna de Judas en la literatura española que, aunque centrada en los Siglos de Oro, se remonta

10.- La imagen negativa del cuerpo de Judas en la visión de Dante es puesta en relación con la de Mahoma de manera muy reveladora por Coffey (2013). García Sala (2002) estudia esa misma representación escatológica de Judas en el Infierno, sentado en el regazo de Satanás, que se repite desde los primeros testimonios en el arte bizantino. Era la visión que se ofrecía desde los inicios del cristianismo, desde la lectura que hacían los Padres de la Iglesia, empezando por Orígenes (como explica perfectamente Laeuchli, 1953). Perea Yébenes (2006) estudia varios epitafios latinos hispanos, cristianos, de época bizantina y visigoda (empezando por el s. vII), que hacen curiosas y relativamente abundantes referencias a Judas en fórmulas de condena religiosa o mágica lanzada contra los que pudieran violar los sepulcros; fórmulas del tipo: «si alguien viola este sepulcro, que le pase como a Judas...». El artículo facilita una magnífica presentación del tema, con múltiples implicaciones. La asociación del cementerio con el "campo de alfareros» de Hechos, que compra y donde se suicida Judas es, entre otros muchos testimonios e interpretaciones del trabajo, especialmente llamativa. Menciono solamente algunos estudios que, por ser más recientes o por presentar casos más específicamente hispánicos, caen fuera del monumental y casi exhaustivo tratamiento del tema del suicidio, incluido el de Judas, por Murray (2000). 
de manera sumaria y precisa a la literatura medieval. ${ }^{11}$ Pese a los ingredientes de morbosidad que le añadían indudable atractivo - por repulsión- popular, la presencia de Judas fue bastante escasa en la literatura medieval culta y continuó siendo relativamente exigua en el teatro áureo, aun siendo éste tan fructífero en otras muchas recuperaciones.

Sin embargo, es revelador comprobar cómo la figuración negativa del Judas avieso y traidor que sembró la Edad Media ha seguido siendo cultivada en las representaciones populares - algunas perviven en procesiones hasta hoy-y en la iconografía, casi siempre a partir de esa versión inaugural que proporcionó Santiago de La Vorágine en la Leyenda dorada, y que él mismo realmente reconocía como apócrifa. Como estudia Propp en Edipo a la luz del folklore ([1944], 1982), se trataba de la leyenda de un Judas con la misma trayectoria biográfica del Edipo, hijo de Layo, que mata a su padre y casa con su madre. ${ }^{12}$ Esta poco canónica leyenda se hizo muy popular y llegaría al teatro medieval, donde se versionó en representaciones teatrales litúrgicas de toda Europa (algunos de sus textos conservados en registros o "consuetas»). ${ }^{13}$ Arellano (2015) analiza las tres únicas piezas áureas hasta ahora conocidas que cuentan con ese Judas legendario como protagonista. ${ }^{14}$ En esas obras se parte homogéneamente de los motivos de la Leyenda dorada y se les suman otros folklóricos, como el del cabello pelirrojo, las botas, la patria calabresa, el saúco como árbol del ahorcamiento, la relación con el judío errante, etc. ${ }^{15}$ Judas, por tanto, además de traidor, se había convertido, ya desde la Edad Media, en un terrible y perverso asesino que llegaba a precipitarse hasta las negruras del incesto. Y un Judas incestuoso era igual o peor que los sodomitas que eran castigados a ser colgados de los pies en el reino de Castilla. ${ }^{16}$

11.- Para su fortuna en la literatura moderna y contemporánea, Grimalt (2004) ofrece un buen repaso de las posturas originales, frente a la traición moralizante ortodoxa, de creadores tan diferentes como Marcel Pagnol, Nikos Kazantzakis, Paul Claudel, Jorge Luis Borges y otros.

12.- Véase también para el tema del Judas folclórico y su entronque con Edipo, muchos años después del trabajo pionero de Gillet (1925), Prat Ferrer (2006) y Bettini y Guidorizzi (2008). Los estudios sobre la leyenda de Judas en el mundo anglófono remontan a Baum (1916a 1916b).

13.- Toldrà (2018) la ha detectado muy bien en el teatro medieval hispánico. Kovács (2008) detalla la profusa trayectoria de la muerte de Judas, como antítesis de la muerte de Jesucristo, en las representaciones medievales. Y Rodríguez Barral (2008) destaca precisamente las convergencias entre la teatralidad y el arte a finales de la Edad Media, incidiendo muy especialmente en la figura de Judas.

14.- Se trataría de la anónima Comedia del nacimiento y vida de Judas (1590), que se suele considerar más bien auto sacramental, de La vida y muerte de Judas (¿1610?) de Damián Salucio del Poyo y de la bastante más tardía Judas Iscariote (1722) de Antonio Zamora.

15.- Ver Prat Ferrer (2006). Para la caracterización negativa de Judas como rubio o pelirrojo, contamos con el sugerente análisis de Pastoureau (2006). Y para el amarillo en su vestimenta, en las arte plásticas y en el teatro, véase De Sas (2013).

16.- Para el tema del ahorcamiento por los pies o boca abajo en la iconografía medieval europea, véase McCullough (1998). Para los casos concretos en la historia medieval, Baldó (2007). 
Algún atisbo de este comportamiento edípico, o al menos parricida, podría detectarse en Pármeno (el Pármeno luciferino tal como lo interpreta Heusch, 2000), quien, al asesinar a Celestina, mata a una figura sustitutiva de la maternal, querida compañera de su propia madre, Claudina (Tozer, 2004).

Hemos dicho que las representaciones populares presididas por la figura de Judas llegan hasta nuestros días. Pervive, en efecto, un tratamiento espectacular del personaje y su leyenda en las celebraciones carnavalescas de la llamada Fiesta de Judas o Quema del Judas, en toda Europa y muy especialmente en regiones de habla hispana, desde España hasta Latinoamérica y Asia. ${ }^{17}$ Tienen lugar estas demostraciones festivas preferentemente el Domingo de Resurrección, cuando un remedo de Judas se cuelga de un poste en forma de muñeco o pelele, hecho con madera o paja recubierto de ropas viejas, trapos o andrajos; lleva en su mano, a veces, la emblemática bolsa de las treinta monedas. En ocasiones, se le hacen estallar bombas o petardos metidos en el cuerpo y se le arroja a las llamas. A veces se lee en voz alta, mientras se consume, el llamado Testamento de Judas, que se emparenta con otros testamentos populares de los que también se conservan testimonios desde hace al menos tres o cuatro siglos en pliegos sueltos (García de Diego, 1973). Son fiestas en las que se anatemiza al traidor, entre el jolgorio espontáneo y la crítica liberadora. ${ }^{18}$

\subsection{Las dos versiones bíblicas del suicidio}

La bolsa de las monedas y el beso son metonimias indiscutibles y convencionales, repetidas con pocas variantes en las lecturas e interpretaciones de la vida de Judas. Un repaso de su iconografía da cuenta de esa monotonía y unanimidad: Judas fue codicioso (bolsa) y fue traidor (beso). Sin embargo, no se presenta tan unísona la lectura, recepción e interpretación de los episodios en torno a su muerte. Las metonimias de ésta se

17.- Además de en España, pervive en Portugal, Grecia, Chipre, Reino Unido, Alemania, Austria, Chequia (declarada su fiesta de la Quema de Judas de interés especial por la unEsCo), Polonia, Eslovaquia, etc. También en Asia, en países de colonización cristiana, como Filipinas. En Latinoamércia, en México, Brasil, Uruguay, Paraguay, Colombia, Venezuela, Chile, Perú o Costa Rica. En España, en Venta del Moro, Talayuelas (Cuenca), Cabezuela del Valle (Cáceres), Samaniego (Álava), Zarzuela de Jadraque (Guadalajara), Algete (Madrid), Yecla (Murcia) y en muchos otros lugares. Véase Calle (2009).

18.- Celebraciones que se mantienen vivas hasta hoy, con todas las contradicciones que cualquier festividad religiosa de raigambre antigua conlleva, con la singularidad en este caso de que el sentido de la fiesta corre el peligro de ser tergiversado y llegar a convertirse en lo que esencialmente no es, en un ataque racista anti-semita. Un buen ejemplo de análisis antropológico de la fiesta en Latinoamérica, centrado en la Fiesta del Burro y Judas, en San Antero (Colombia), lo ofrece García-Dussán (2019). El autor descubre procesos de transculturación de otros eventos, centrados en un símbolo (el del pobre animal) que pone en entredicho vicios públicos, permite exorcizar el mal social y corregir imaginariamente graves defectos en la realidad compartida. 
encuentran mucho más abiertas a la hermeneusis y pueden ser incluso discrepantes: la caída, el suicidio, la horca... Con todo, desde los inicios del cristianismo, Judas se identifica con el discípulo falso, traidor a Jesús, el Suicida, en las antípodas del Hijo de Dios, pero en su muerte casi al mismo nivel o tamaño de extremosidad, como hemos visto: la Horca frente la Cruz (Fig. 3).

Hay dos versiones en el Nuevo Testamento para el suicidio de Judas. En la primera, la más divulgada y representada figurativamente, se ahorca para suicidarse; en la segunda, menos difundida, pero en la que más nos interesa ahora incidir, se arroja desde una altura para igualmente suicidarse. Tanto en la una como en la otra - en el ahorcamiento y en la precipitación desde lo alto- se hacen sensibles y visibles las consecuencias de la muerte abominable, a través de imágenes truculentas de las vísceras que extraen y se llevan en rapiña los demonios, en el primer caso, o que quedan desparramadas por los suelos, en el segundo caso.

Foucault (1976), en su Vigilar y castigar, estudió la desaparición progresiva de los espectáculos abiertos y populares de ejecución pública y festiva, desde la horca hasta la decapitación; cómo fueron dando paso entre los siglos XVIII y XIX a la punición legal colectiva, de observación panóptica. De hecho, la veracidad histórica de esta expulsión o emulsión de entrañas que veremos en las imágenes de la muerte de Judas la confirman hasta muy tardíamente episodios brutales como el del descuartizamiento atroz de un reo, en la París de 1757, con el que se abre la obra de Foucault. Y ese exhibicionismo pervive como simulacro, simbólicamente, en muchos de los episodios de recreación popular de la Fiesta de Judas que acabamos de mencionar: caídas, golpes, traumatismos, explosiones (de pequeñas bombas o petardos), vejaciones de todo tipo, etc. El castigo no es una represalia punitiva, sino un rito político, y estos epígonos festivos son residuos de los intentos de apropiación carnavalesca, desde la Edad Media, como los veía Bajtín, de esos ceremoniales abiertos a la comunidad y que se resisten a ser confinados entre muros institucionalizados. Pues bien, esas vísceras, entrañas o "sesos», como los que se rompen obscenamente en el suicidio de Judas, verdaderos detritos de atrocidad, aparecerán explicitados igualmente como piezas truculentas, pecios de naufragio nutridos de valor y significado, tanto en la literalidad de los textos celestinescos, como en muchas de las ilustraciones de las muertes de los criados y del propio Calisto. ${ }^{19}$

19.- Así lo ha visto, con suma sagacidad, Sanmartín, quien afirma de estos tres muertos descoyuntados: «acaban sin cabeza, es decir, sufren la mayor humillación, el descabezamiento, especialmente deshonroso en la figura de un noble como es Calisto. Pero es que además, en su caso, su cabeza aparece dividida en tres partes y tiene los sesos fuera, que quedan desparramados en unos cantos y serán recogidos por Sosia...» (2007: 117). Y añade: "Sobre ese desparramamiento de los sesos abundará después Melibea: "de la triste caída sus más escondidos sesos quedaron repartidos por las piedras y paredes" (XXI, 333). También a uno de 
Aunque la relación entre codicia y castigo mortal está presente en las dos versiones evangélicas de la muerte de Judas, la sombra de la segunda (la de Hechos) es la que se cierne más directamente sobre tres de las cinco muertes de La Celestina: las de Sempronio, Pármeno y Melibea. ${ }^{20}$ Ninguno de ellos se ahorca, como ocurre en la primera versión evangélica con Judas. Sempronio y Pármeno tampoco se suicidan realmente, pero su huida precipitada - agravada por el remordimiento tras el horrendo crimen cometido- les conduce a tener que saltar desde una altura, quedando gravemente heridos. Ese salto al vacío, de cabeza, no está suficientemente motivado por la desesperación, que en cambio sí que justifica claramente el suicidio de Melibea. Sí que es, con todo, un justo castigo a su innecesario crimen, castigo que de algún modo ellos mismos persiguen y se merecen. Como le reporta Sosia a Calisto: «quedan descabezados en la plaza como públicos malhechores, con pregones que manifestaban su delito» (XIII, 266). E insistirá en lo mismo, poco después: «la causa de su muerte publicaba el cruel verdugo a voces, diciendo: 'Manda la justicia mueran los violentos matadores'» (XIII, 267).

Pero volvamos a Judas y veamos las dos versiones evangélicas de su muerte con más detalle. El Nuevo Testamento registra la muerte de Judas dos veces: en el Evangelio de Mateo (27: 3-8) y en los Hechos de los Apóstoles (1: 16-19).

En la primera versión, el Evangelio de Mateo dice:

3 Entonces Judas, el que le había entregado, viendo que era condenado, devolvió arrepentido las treinta piezas de plata a los principales sacerdotes y a los ancianos, 4 diciendo: "Yo he pecado entregando sangre inocente». Mas ellos dijeron: «¿Qué nos importa a nosotros? ¡Allá tú!». 5 Y arrojando las piezas de plata en el templo, salió, y fue y se ahorcó. 6 Los principales sacerdotes, tomando las piezas de plata, dijeron: «No es lícito echarlas en el tesoro de las ofrendas, porque es precio de sangre». 7 Y después de consultar, compraron con ellas el campo del alfarero, para

los criados, como se ha visto reflejado en la cita anterior, se le van cayendo los sesos, camino de la degollación (XIII, 267). Los sesos pueden convertirse en texto simbólico; el lector-oidor coetáneo a Rojas, buen interpretador de símbolos y alegorías, podría entender una referencia a la falta de seso en esos amores locos de Calisto o en ese homicidio innecesario de Celestina que cometen los criados. De hecho, la falta de seso es mencionada de modo metafórico durante muchos momentos de la obra, relacionándola generalmente (tópico de la época) con la locura de amor y la pérdida de la cordura» (2007: 117-118).

20.- Podría incluirse una sexta muerte, la de Claudina. Lo hacen algunos autores, como Iglesias (2015), cuando estudia las implicaciones legales de estas muertes. Pero la suya no es una muerte contemplada "en directo», como las otras, sino contada o referida a unos hechos sucedidos con mucha anterioridad. 
sepultura de los extranjeros. 8 Por lo cual aquel campo se llama hasta el día de hoy: "Campo de sangre». ${ }^{21}$

Judas, en la lectura evangélica, arrepentido, pretende volver y devolver las treinta monedas, pero los sacerdotes del templo no aceptan esa devolución y desprecian su arrepentimiento tardío. Entonces, arroja las monedas y se cuelga (se suspendit). La secuencia con ambas acciones - la negativa del sanedrín y el suicidio, horas después- se refleja en una misma imagen en la Biblia inglesa de Holkham (c. 1320-1330), ${ }^{22}$ así como en varias miniaturas de Biblias moralizadas, reproducidas y muy bien estudiadas por Lafran (2007).

El suicidio - «salió, y fue y se ahorcó»— viene como una reacción impulsiva por remordimiento y causado por la desperatio ante la falta de perdón. ${ }^{23}$ La desesperación no es un estado depresivo ni melancólico, sino un desorden airado. Cuando Giotto ha de representar, dentro del ciclo de los Siete Vicios, en la Capilla de los Scrovegni de Padua (1305-1306), el vicio de la Desesperación, dibuja a una mujer ahorcándose (bajo una barra y un dintel que luce la cartela de DESPERATIO), con el demonio acudiendo desde arriba, como un ave de presa, a arrebatar su alma (Fig. 4). En el fresco, aunque el personaje alegórico sea femenino, Giotto, según los críticos, sigue los motivos gráficos precedentes del suicidio de Judas.

21.- «3 Tunc videns Judas, qui eum tradidit, quod damnatus esset, poenitentia ductus, retulit triginta argenteos principibus sacerdotum et senioribus, 4 dicens: "Peccavi, tradens sanguinem justum". At illi dixerunt: "Quid ad nos? Tu videris". 5 Et proiectis argenteis in templo, recessit: et abiens aqueu se suspendit. 6 Principes autem sacerdotum, acceptis argenteis, dixerunt: "Non licet eos mittere in corbonam: quia pretium sanguinis est". 7 Consilio autem inito, emerunt ex illis agrum figuli, in sepulturam peregrinorum. 8 Propter hoc vocatus est ager ille, Haceldama, hoc est, 'Ager sanguinis', usque in hodiernum diem».

22.- Recogida en el ms. Add. 47682, f. 30 de la British Library: <https://www.akg-images. com/archive/-2UMEBMYZ5HNIB.html>.

23.- Tras el suicidio, los principales sacerdotes piensan que es inapropiado devolver el dinero al tesoro del templo (de donde había salido), porque era "precio de sangre». Entonces, después de discutir el tema, deciden emplearlo para comprar un campo llamado "campo de alfarero", que Mateo dice que, al hallarse manchado por su origen (el dinero de la traición), se llamará a partir de ese momento "Campo de sangre». 


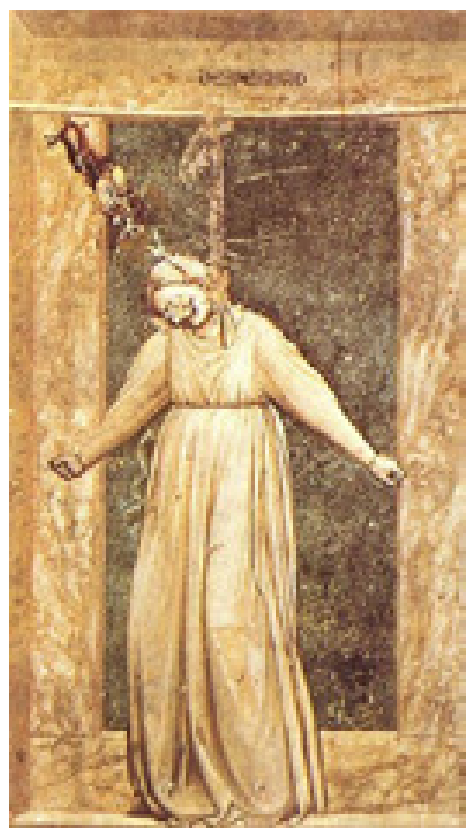

Fig. 4. Desperatio. Capilla de los Scrovegni, Padua (1305-1306)

En la segunda versión, en Hechos de los Apóstoles (1: 16-19), el relato del suicidio está puesto en boca de Pedro. Pedro explica que Judas muere ca-

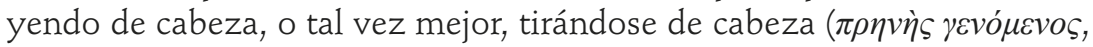
en el griego original), en un lugar (un "campo") previamente comprado o adquirido con el dinero de la traición a Jesús:

16 -Hermanos, tenía que cumplirse lo que el Espíritu Santo, por medio de David, había dicho en la Escritura acerca de Judas, el que sirvió de guía a los que apresaron a Jesús. 17 Judas era uno de los nuestros y tenía parte en nuestro trabajo. 18 Pero fue y compró un terreno con el dinero que le pagaron por su maldad; cayó luego de cabeza, y reventó y se le salieron las entrañas. 19 Cuando los que vivían en Jerusalén lo supieron, llamaron a aquel terreno Hacéldama, que en su lengua quiere decir "Campo de Sangre». ${ }^{24}$

24.- «16 -Viri fratres oportet impleri scripturam quam praedixit Spiritus Sanctus per os David de Iuda qui fuit dux eorum qui conprehenderunt Iesum 17 quia connumeratus erat in nobis et sortitus est sortem ministerii huius. 18 Et hic quidem possedit agrum de mercede iniquitatis, et suspensus crepuit medius: et diffusa sunt omnia viscera eius. 19 et notum factum est omnibus habitantibus Hierusalem ita ut appellaretur ager ille lingua eorum Acheldemach hoc est ager Sanguinis». 
La explicación más completa de estas interpretaciones bíblicas la ofrece Murray (2000), quien dedica al personaje un extenso capítulo (2000: 323-368), extraordinariamente pormenorizado, dentro de su imprescindible monografía sobre el suicidio en la Edad Media. ${ }^{25}$ Este pasaje segundo, en concreto, no es fácil de entender de manera cabal, pues reviste múltiples implicaciones, algunas de las cuales trataremos de desmenuzar, siguiendo básicamente a Murray. Pero quedémonos por el momento con el aspecto más llamativo para nosotros del mismo. Judas, «cayó [...] de cabeza», evidentemente tirándose o saltando al vacío, de resultas de lo cual revienta por el medio y sus entrañas o vísceras quedan derramadas o esparcidas. Aunque la "caída» fue traducida en la Vulgata por suspensus (suspensus crepuit medius), la traducción al castellano de Reina Varela re-

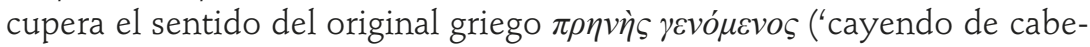
za'). Casi ninguno, entre los exégetas de este pasaje (de ambos pasajes), propone que se trate de una caída accidental, ni duda de que se trate de un suicidio, como el que ya atestiguaba la versión presentada por Mateo (Murray, 2000: 335). La lección evangélica no facilita que sepamos exactamente desde dónde se arroja Judas, aunque habría de ser desde una altura también considerable - elevación natural, edificio o torre-, yendo a dar al suelo en ese agrum, solar o campo recién adquirido. En todo caso, esa muerte es aún más contradictoria que la de los criados en La Celestina, porque cuando uno cae de cabeza, o incluso queda colgado (suspensus), tampoco revienta por medio (crepuit medius) ni se le abren ni esparcen las entrañas del vientre (et difusa sunt omnia viscera eius).

El relato de Hechos comienza aludiendo, como hace Mateo, al ager sanginis ("Hacéldama»). Aunque en Mateo los sacerdotes compran el campo para limpiar o lavar la procedencia sucia de las monedas de la traición, mientras que aquí es Judas quien compra el campo con la recompensa de su iniquidad: "adquirió un campo con un salario injusto». Y a continuación viene la discordancia mayor, porque se presenta esta versión del todo distinta a la que Mateo ofrece de su muerte: «adquirió un campo con un salario injusto y, cayendo de cabeza, reventó por medio y se esparcieron todas sus entrañas». Los Hechos no dicen explícitamente, por tanto, que

25.- Para el tema del suicidio en la Edad Media, los volúmenes de Murray se pueden complementar con la monografía dedicada a la muerte voluntaria en Occidente de Minois (2009), el libro básico sobre el arte del suicidio de Brown (2001) y el trabajo compilatorio de Andrés (2003). Un precedente fundamental es el artículo de Schmitt (1976). Reviste también interés, para el debate entre literatura y suicidio, Zambrano (2006). Posteriormente, centrado de nuevo en la Edad Media y en los campos textual e iconográfico de la figura del Judas suicida, además del ensayo sobre el lugar de Judas en la cristología de Cane (2005), es fundamental la consulta del estudio de Lafran (2007) sobre la muerte de Judas en las Biblias moralizadas. Sendos panoramas recientes sobre el papel del personaje (incluyendo las versiones sobre su suicidio) y su progresiva asociación e identificación con el judaísmo, ofrecen primero Saari (2006) y, más recientemente, Ryan (2019). 
Judas se suicidó (ni que se ahorcó), sino que cayó «de cabeza». El griego original lo expresa literalmente del siguiente modo:

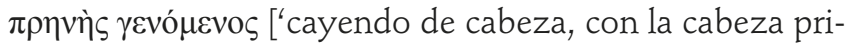

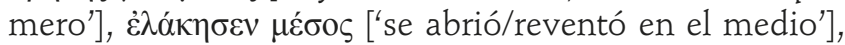

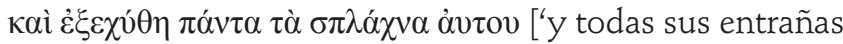
salieron'].

El contraste entre esos dos relatos esencialmente dispares suscitó comentarios en la Iglesia desde el principio. Algunos comentaristas eligieron un enfoque filológico, interpretando el verbo que utiliza Mateo en su pasaje, $\dot{\alpha} \pi \dot{\alpha} \gamma \chi \varepsilon \sigma \theta \alpha l$, como 'matarse por cualquier manera', en vez de

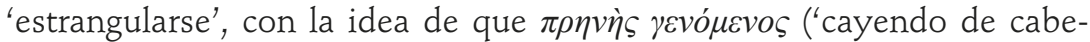
za') significara lo mismo que ese $\dot{\alpha} \pi \dot{\alpha} \gamma \chi \varepsilon \sigma \theta \alpha l$, es decir 'ahorcase'. Por otra parte, se propuso también en algún momento que las palabras de Hechos podrían ser interpretadas de una manera más cercana al suicidio, con la

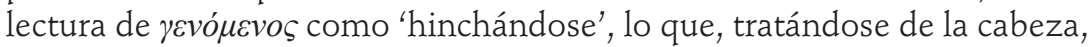
podría ser compatible con el ahorcamiento. Para conciliar las divergencias entre ambos textos, otros comentaristas llegaron a sugerir que cuando Judas se colgó, la rama con la cuerda se rompería, de modo que su cuerpo caería y reventaría al golpear el suelo. Sin embargo, para que esto hubiera podido darse, Judas tendría que haber sido "ahorcado por los pies», algo nada extraño desde el punto de vista histórico, pero sin documentación que se pueda asociar con Judas. ${ }^{26}$

Con el tiempo, los comentaristas bíblicos fueron dejando de lado estas soluciones más o menos rebuscadas o imaginativas, de compromiso, y aceptando y reconociendo que probablemente no había un relato único, sino dos tradiciones no sólo diferentes, sino en gran parte discrepantes. Es lo que Murray denomina una split tradition ('tradición dividida'), frecuente en los relatos de suicidios desde la Antigüedad. En concreto, en la misma época, esa división o escisión se puede leer en el suicidio de Poncio Pilato (tras caer en desgracia ante Calígula, según la versión de Eusebio de Cesarea, en el s. III) y en el de Nerón. En la split tradition, una corriente de memoria colectiva informa de la muerte como suicidio, mientras que otra la representa como muerte natural o como crimen ajeno, es decir, como resultado de la violencia de otros (Murray, 2000: 336).

Teniendo en cuenta que se reconoce que Mateo extrajo una parte de su Evangelio de otro evangelio más corto perdido (la llamada versión ' $Q$ '), compartido con Marcos, y que el pasaje sobre la muerte de Judas no está

26.- El monográfico sobre el tema, en el Bulletin de la Société d'anthropologie de Lyon de 1905, llevaba un artículo de M. Edmond Locard titulado «La mort de Judas Iscariote (Étude critique d'exégèse et de médecine légale sur un cas de pendaison célèbre)» (pp. 104-130). La discusión acerca de qué tipo de ahorcamiento podría llevar, como en el caso de Judas, al estallido de una persona por el medio, arrojando sus entrañas fuera del cuerpo, ocupó una sección importante de ese número (Murray, 2000: 355-356). 
en Marcos, Murray propone como probable que Mateo lo tomara directamente de una tradición oral, es decir, de noticias propagadas en la segunda mitad del siglo I (entre c. 65 y c.100), que es cuando Mateo escribiría su texto. La redacción de Hechos, normalmente atribuida al evangelista Lucas, se suele fechar entre c. 70 y c. 95, es decir, muy cercana a la de Mateo, tal vez un poco posterior. Para explicar sus divergencias, la crítica bíblica más reciente ha considerado, además de las fechas, las características literarias de las dos versiones. Ambas apuntaban a tratar de mostrar la figura y actos de un traidor que forzosamente tiene que recibir un castigo y llegar a un mal final, a un desenlace trágico. Y ambas lo hacían con una alusión más o menos explícita al cumplimiento de la letra de alguno de los Salmos dedicados a invectivas contra la traición y maldiciones al enemigo (especialmente los Salmos 108 y 109). Nada le vale el arrepentimiento (la oración) al impío: «Pon sobre él al impío, / y Satanás esté a su diestra. / Cuando fuere juzgado, salga culpable; / y su oración sea para pecado» (Salmo 109: 6-7).

En Mateo, el traidor ahorcado replicaría el motivo del más conocido traidor suicida del Antiguo Testamento, Ajitófel, quien traicionó al rey David, como cuenta el Libro II de Samuel, 15-17. La traición y el suicidio presiden la historia de este consejero, que claramente prefigura a Judas y cuya sombra pienso que igualmente podría alargarse - siempre pasando por la más reconocida de Judas - hasta la traición de Pármeno en $L a$ Celestina. Porque Ajitófel es un mal consejero, un traidor a David, que aparece en pareja antitética con Jusai, el buen consejero, fiel al mismo rey. No es que Sempronio sea un mal consejero y Pármeno el buen consejero (aunque se pueda detectar esa diferencia al principio de la obra de Rojas), sino que la dualidad y contraste ente consejeros parece llamativa. Pero volviendo al episodio de la traición de Ajitófel a su señor, tal vez el miedo de encontrarse de nuevo ante un David victorioso sea lo que le lleve al suicidio (Murray, 2000: 336-337). ${ }^{27}$

27.- Cuando Absalón inicia su revuelta contra su padre, Ajitófel le da la espalda a David (Salmos, 41, 9; 55, 12-14) y abraza la causa de Absalón (II Samuel, 15:12). Todo lo que sigue en torno a las discrepancias entre sus consejos y los del otro experimentado consejero, Jusai, que condirán a un callejón sin salida y al suicidio en la horca (para evitar ser acusado de traición) a Ajitófel, están narrados en II Samuel, 15-16. 


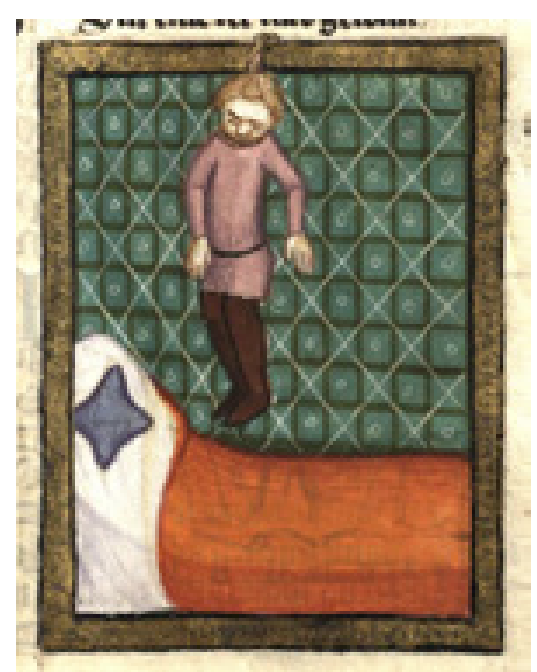

Fig. 5. Suicidio de Ajitófel. BNF, Ms. latino 392, fol. 92

A diferencia de Absalón, cuya muerte "ahorcado» o estrangulado accidentalmente al huir de su padre, mucho más conocida que la de Ajitófel, fue objeto de abundantes ilustraciones ya desde la Edad Media, las imágenes de Ajitófel, que yo conozca, son excepcionales (Fig. 5). Sí que las hubo, en cambio, de otro traidor notable, Ocozías, como más adelante veremos. Pero es Absalón quien, en opinión de Lafran (2007), recoge la huella de Ajitófel y se convierte en el más conspicuo antecedente de Judas para los lectores medievales. Y su estrangulamiento - tan teatral y dramático casi como el ahorcamiento de Judas- se leerá, más que como accidente, como castigo justo de su falta.

Ecos como estos y otros pocos del Antiguo Testamento han llevado a algunos críticos bíblicos hasta la sugerencia de que los relatos de la muerte de Judas pudieron haber sido invenciones literarias, e incluso, en algún caso excepcional, a la posibilidad de que la existencia de Judas pudiera haber sido igualmente inventada. Pero Murray disiente taxativamente de esos recelos, aduciendo la antigua regla del historiador medievalista frente a las evidencias narrativas: un mal relato suele implicar una buena historia detrás. Es decir, suele ser el resultado de una historia verídica: «bad story, good history». Es lo que la ecdótica llamaría un error conjuntivo, que puede conducir retrospectivamente a buenas lecturas (o suposiciones) en un texto bonus o melior. Hemos visto que tanto el Evangelio de Mateo como Hechos vinculan la muerte de Judas con la compra de un cierto campo, pero lo hacen de manera bastante incoherente, inconsistente internamente y entre sí, lo que convierte sus versiones en "malos relatos» (no se entiende la relación entre el dinero de la traición, la compra del campo y la muerte, elementos que se presentan de manera inconexa). Por tanto, no 
sería descartable sino presumible que esos «malos relatos» hubieran modificado, falseado o deturpado una tradición verdadera anterior.

Siguiendo a Murray, la tradición no escrita sobre la traición y muerte de Judas podría haber sido recordada durante unos treinta o cuarenta años oralmente, y durante ese dilatado tiempo se habría ido bifurcando o dividiendo (split tradition). Apelando a la crítica moderna, aparentemente hay muchos aspectos en el relato de Mateo, en su Evangelio, que lo vinculan con la tradición de los cristianos de Jerusalén. Mateo probablemente escribía también para los conversos cristianos (conversos del judaísmo), que necesitaban un refuerzo especial para no volver a caer en las viejas creencias judaicas. Por ejemplo, Mateo coloca el remordimiento estéril de Judas justo después del arrepentimiento fértil de Pedro (Mateo 26, 69-75), contrastando implícitamente al Judas tardíamente arrepentido, judío por excelencia, con Pedro, que era galileo (y por tanto eminente cristiano), y que reconoce su culpa, llora contrito y pesaroso, y es perdonado (Murray, 2000: 337-338). Recordaremos más adelante, por cierto, en La Celestina, algunas actitudes del bravucón Centurio que nos evocan al Pedro más popular, blandiendo la espada en un ademán que no puede faltar en las representaciones del Prendimiento.

Todas estas presunciones no resuelven la pregunta, que queda en el aire, sobre si el suicidio de Judas fue agregado o fue eliminado - o tratado de mitigar - de la tradición. Es decir, si Judas murió de muerte natural, por una contingencia, y fue la tradición de Mateo la que modificó el carácter de su muerte al trasmitirla como suicidio; o si, por el contrario, fue la tradición de Lucas (en Hechos) la que hizo la innovación, encubriendo un suicidio como una supuesta muerte espontánea, por caída accidental. Al parecer, en el siglo I, bajo el Imperio Romano, el suicidio era menos vergonzoso que sufrir la vejación de caerse de cabeza primero y reventar luego por medio. Bajo esta suposición, Mateo estaría humanizando o limpiando en parte la memoria de Judas, que habría hecho lo más decente y honroso en su situación, ahorcándose al darse cuenta de la trascendencia de su culpa. Sin embargo, las opiniones judías del primer siglo sobre el suicidio son demasiado ambivalentes para apoyar esa lectura.

$\mathrm{Y}$, al fin y al cabo, los comentaristas medievales tampoco se plantearon tan sesudamente como harían los posteriores todos estos problemas en torno a la split tradition sobre Judas, puesto que partían de la comodidad uniforme que había trasmitido la versión bíblica de san Jerónimo. $\mathrm{Al}$ convertir la Biblia hebrea y griega en Vulgata a finales del siglo Iv, Jerónimo había resuelto el choque entre las dos muertes de Judas, haciendo leer en ambas versiones al unísono que se había tratado de un ahorcamiento: suspensus. De ahí también la unanimidad iconográfica, con una figura de Judas ahorcado y nunca de un Judas arrojándose o cayendo al campo de sangre. 
Jerónimo eligió hábilmente el término latino suspensus para reemplazar

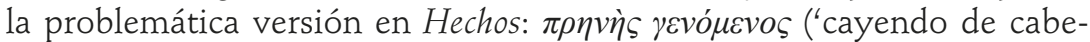
za'). Los clérigos medievales leyeron siempre, por tanto, en Hechos, 1, 18: et suspensus crepuit medius et diffusa sunt omnia viscera eius [' $Y$ estando suspendido/colgado, estalló en el medio y todas sus entrañas/vísceras se dispersaron']. Y aunque suspensus no signifique literalmente 'ahorcado', el contexto conduce a esa interpretación y, además, está lo suficientemente cerca de otro término, suspendiosus, que sí que significa definitivamente 'ahorcado'. De manera que esa versión sería indistinguible del significado de $\alpha \dot{\alpha} \alpha \dot{\gamma} \chi \varepsilon \sigma \theta \alpha$ de Mateo. ${ }^{28}$

Por tanto, dado que el texto griego original de los Hechos no estuvo disponible para los comentaristas medievales hasta principios del siglo XIII, tampoco existió en la Edad Media esa contradicción o rompecabezas en torno a la muerte de Judas que iba a obligar a todo tipo de elucubraciones a los eruditos posteriores. Como dice Murray, Jerónimo, con su simplificación, había hecho un enorme favor a los lectores de la Biblia en la Edad Media. Al pensar que el suicidio era una solución extrema, absolutamente negativa, abominable y perversa, Jerónimo decidió que sería también, en consecuencia, acorde con la catadura del personaje, la más idónea para el final de Judas. De acuerdo con esa presuposición, Jerónimo había reducido o unificado las lecturas interpretativas de los textos griegos, eliminando sus ambigüedades. ${ }^{29}$

\subsection{La iconografía de Judas ahorcado}

La iconografía de los episodios principales para el cristianismo de la vida de Judas ha sido bien estudiada. Robson (2001), aunque se limita en su tesis a la imagen de Judas en la pintura italiana tardo-medieval, enumera, reproduce y analiza pormenorizadamente sus figuraciones: hasta 7 ligadas a la Entrada a Jerusalén, 10 relacionadas con su presencia junto a Jesús en la casa de Simón, 18 con la Toma de la bolsa de las monedas, 56 con la presencia de Judas en la Última Cena, 8 con el Lavado de los pies de Jesús, 31 con la Traición (el Beso traidor), 5 con la Devolución de las monedas y 18 con la Muerte de Judas (en el Infierno o ahorcado). Además,

28.- Saari (2006), en su monografía sobre la muerte o muertes de Judas — many deaths, como puntualiza desde el título de su trabajo-, impecable académicamente, pero escrita desde el dolor por la muerte suicida de su hermano mayor, defiende, más que la influencia de la lectura unificadora de Jerónimo, el posterior monopolio interpretativo de Tomás de Aquino, a partir del intento de los seguidores de Marcos por destruir el equilibrio monolítico del grupo de los doce apóstoles. Aquino no dejaba alternativas, para Saari, a la lectura única de lo que significaría el personaje respecto a Jesús.

29.- Tal «armonización» de textos sagrados, incluso en ausencia de traducción del griego, no era, de hecho, nada raro en estos primeros siglos cristianos (para desconcierto de eruditos de la crítica textual posteriores). En definitiva, lo que Murray (2000: 339) denomina gráficamente «juego de manos piadoso» no habría resultado nada excepcional en la labor erudita de Jerónimo. 
aporta otras 116 imágenes misceláneas, con sus respectivos comentarios, relacionadas no directa, sino indirectamente con el personaje. ${ }^{30}$

Nos interesa, sin afán de exhaustividad, centrarnos en algunas de esas 18 imágenes de la muerte. Casi todas giran, como discrimina Robson, en torno a dos fotos-fijas: Judas en el Infierno o Judas ahorcado (si bien pueden darse ambas combinadas). Son las que nos ofrecen los testimonios italianos — quizás sean éstos los más conocidos, como el de Lorenzetti, en Asís (Fig. 6)-, pero también los hispánicos o del resto de Europa. Testimonios que se prolongan hasta el siglo XVI, en frescos como el del monasterio de Strupets (Bulgaria) (Fig. 7), y que continuarán en siglos posteriores.

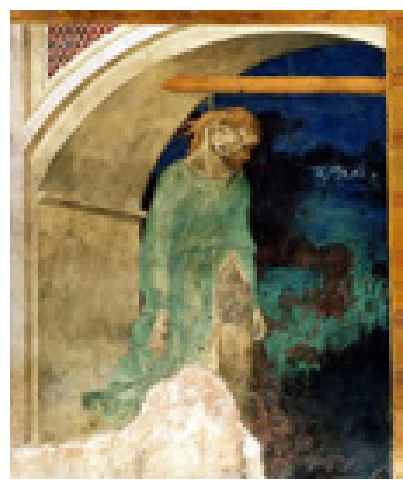

Fig. 6. Pietro Lorenzetti, Judas ahorcado. Basílica inferior de San Francisco (Asís)

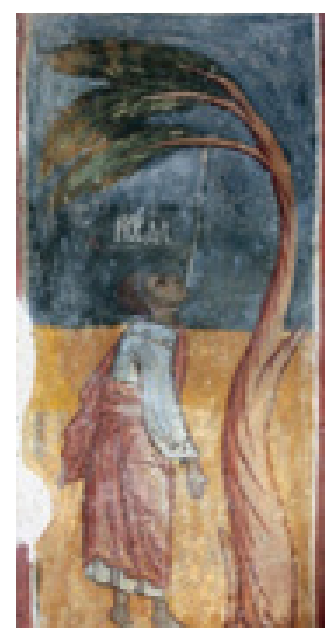

Fig. 7. Judas Iscariote. Fresco del s. XVI.

Monasterio de Strupets (Tarzhishte), Bulgaria. 
El cristianismo, ya en el arte romano del siglo iv, asocia la falta de lealtad y la codicia con el castigo de la horca, como en el lateral derecho del panel trasero de la primorosa cajita de marfil (Fig. 8), tal vez relicario, datada en este siglo. ${ }^{31}$ Este panel labrado nos muestra la figura de un ahorcado, que podría ser Judas (los historiadores del arte proponen que lo sea, atendiendo al contexto), junto a la escena de la traición de Ananías, según el episodio que se relata en Hechos (5: 1-11), sugiriendo la pena que este último habría merecido también. ${ }^{32}$

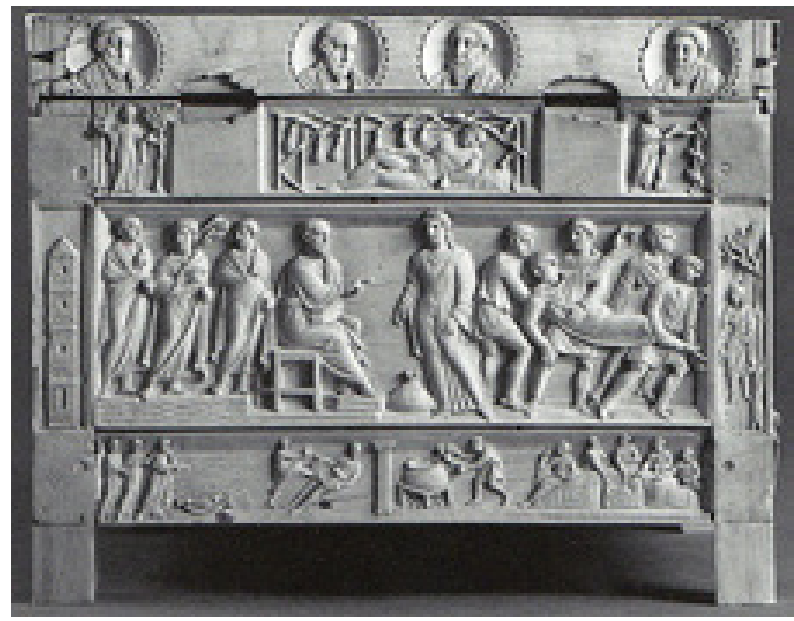

Fig. 8. Relicario, panel trasero. Torre, juicio de Ananías y Safira, y suicidio de Judas. Marfil, norte de Italia (¿Milán?), siglo iv. Brescia, Museo Civico

En la iconografía medieval, el castigo al avaro se explicita sometiéndolo a todo tipo de tormentos infernales: ahorcado, pero también hervido en una caldera o ahogado en el río. El atributo de la causa simbólica de su condena (la bolsa, las monedas) se suele destacar en la composición. Una de las identificaciones más llamativas entre avaricia y ahorcamiento nos la confirma el tímpano de la portada occidental de la Abadía de Conques (Francia), de comienzos del siglo xII, donde el avaro, que no sabemos si puede ser Judas, aparece ahorcado de un árbol con la bolsa del dinero anudada al cuello (Murray, 2000: 382). Pero más claramente se suele proponer ya una identificación con Judas del ahorcado que aparece en dos capiteles que muestran su ahorcamiento, en sendas iglesias principales de

31.- Extrañamente, ni Murray (2000), ni Robson (2001), ni otros autores incluyen en sus estudios este notable precedente de la figuración del suicidio de Judas.

32.- Ananías (como hará Judas) retiene parte del precio prometido para la iglesia, mintiendo a los apóstoles. Y tras ser acusado por Pedro, cae fulminado. Su historia serviría como advertencia a quienes, por avaricia, se quisieran aprovechar de la iglesia naciente. Ver McGowan (2011) para el estudio de la pieza artística. 
Autun y Vézelay, en Francia, ambos de entre 1230 y 1240. En San Lázaro de Autun (Fig. 9), el capitel hace pareja, en la nave central de la catedral, con el de la muerte de Caín, ilustrando entre ambos los castigos a estos dos máximos exponentes bíblicos del crimen y la traición. En el caso de Judas, los dos demonios tiran de una cuerda atada a algo redondo que podría ser, de nuevo, la bolsa de monedas.

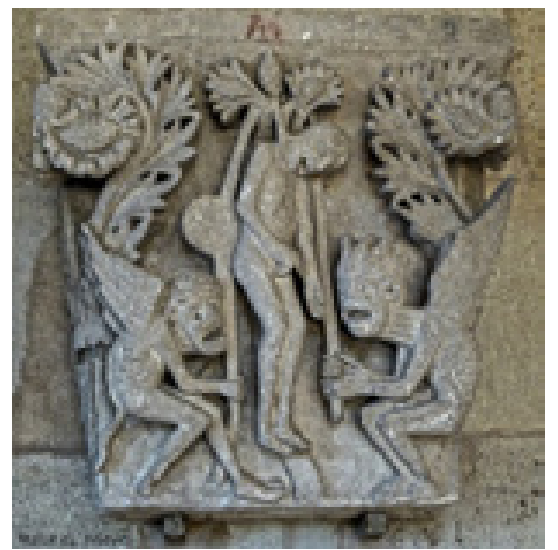

Fig. 9. San Lázaro de Autun (Francia) c. 1230-1240

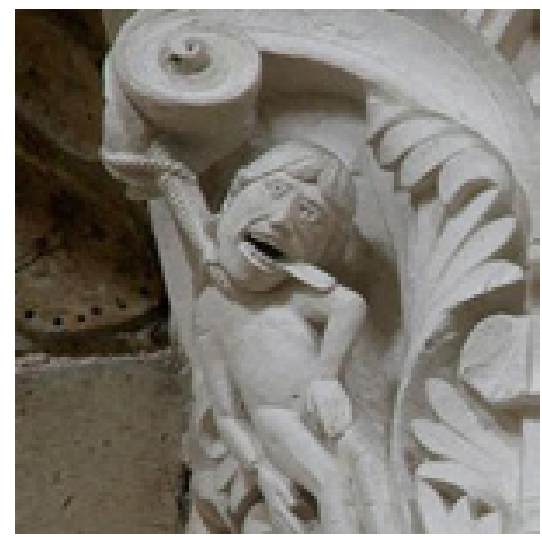

Fig. 10. María Magdalena de Vézelay (Francia) c. 1230-1240

El capitel de la basílica de María Magdalena de Vézelay (Fig. 10), muestra a un Judas desnudo, como el de Autun (parecen ambos tapar con una mano sus vergüenzas), pero sin la compañía de los demonios. A cambio, la prominencia de la lengua, salida de una boca desproporcionadamente grande y abierta, es absolutamente espectacular y compensa esta ausencia demoníaca (Murray, 2000: 328-329). Insistamos en que también aquí, como en Autun y en los otros testimonios religiosos y artísticos que se 
pueden aportar, hemos de presuponer la identificación con Judas, puesto que no está nunca explicitada. ${ }^{33}$

Esta imagen no es insólita, ni deja de ser realista históricamente. Y me refiero no sólo al ahorcamiento como castigo legal, sino al reflejo de la persona, mujer u hombre, que ponía fin a su vida de manera más o menos voluntaria, ahorcándose. Schmitt (1976) estudia algunas estadísticas en la Edad Media sobre suicidas o - puesto que sabemos que el «suicidio» como denominación no existe hasta finales del siglo XviII- personas que acaban con su propia vida en un acto de desesperación, enfermedad, intoxicación (por alcohol) o locura; ya sea la enajenación por ira (furor, furia o frenesî), ya por melancolía. La mayoría se cuelgan o ahorcan, pero unos pocos, en cifra nada despreciable, se tiran desde una altura (un acantilado o el piso alto de una casa). ${ }^{34}$

En estas imágenes, literarias y figurativas, el esparcimiento de las entrañas del suicida sólo aparece en los testimonios de ahorcamiento (plano estático), pero no en los de salto al vacío (plano dinámico). Precisamente hemos observando una cierta incoherencia, en Hechos, entre la caída de cabeza de Judas y el desperdigamiento de sus vísceras: "cayendo de cabeza, reventó por medio y se esparcieron todas sus entrañas». Si se le desgarran las entrañas y dispersan las vísceras es probablemente porque interfiere o contamina la imagen tomada del primer suicidio (el narrado por Mateo), cuando Judas, atormentado por su crimen, presa de la desperatio, se ahorca. Aunque en ese ahorcamiento no dice nada Mateo sobre las entrañas abiertas, las interpretaciones gráficas posteriores rasgaron la piel y las mostraron extraídas, de modo expresionista, que se nos puede antojar hoy grotesco, para acentuar su obscenidad..$^{35}$ Habría sido plausible que se abrieran de manera natural, por acción de aves carroñeras, o tal vez - más especulativamente- por intervención de alguien, como se abrió el costado de Jesús en la cruz por la acción del soldado romano. El mismo apóstol Pedro, con el fin de rematar a Judas, pudo haber abierto el vientre de Judas en ambos casos — horizontalmente, en el suelo, en Hechos; o en vertical, ahorcado, en Marcos- con un filo cortante, si tenemos en cuenta la impulsiva reacción con que el discípulo había esgrimido ya antes su espada y demostrado su violencia contra un soldado romano. ${ }^{36}$

\section{3.- Véase para esos otros testimonios, en especial, Murray (2000) y Robson (2001).}

34.- De un total de 53 casos examinados por Schmitt, 32 se suicidan ahorcándose, 12 ahogándose, 5 con un cuchillo y 4 tirándose desde una altura. La proporción es de 40 suicidas hombres frente a 13 mujeres (1976: 5). Una proporción que se suele mantener en algunos de los casos medievales hispánicos estudiados (Baldó, 2007).

35.- En alguna imagen, salidas del bajo vientre, las vísceras, al ocupar el lugar de los órganos genitales masculinos, se muestran como intestinos revueltos y repulsivos.

36.- Es lo que hace el alguacil de la derecha a uno de los dos criados de Calisto en el grabado de Sevilla, 1523 (Fig. 2). Tal vez Pedro tuviera razones para dar esta versión de la muerte de Judas, que no se corresponde con la versión más común, que fue la que adoptó la iconografía: 
En todo caso ambas imágenes, la del ahorcamiento y la del esparcimiento truculento de las entrañas, se funden en numerosas representaciones medievales de la muerte de Judas ahorcándose. La imagen repulsiva de ese vientre abierto, diffusa omnia viscera eius, la representa muy bien - no es la única, pero sí una de las más expresivas y terribles- la espantosa pintura al fresco que Giovanni Canavesio plasmó, a finales del siglo Xv, en tiempos de composición de La Celestina, como tabla lateral de otra Crucifixión, esta vez en la basílica de Notre-Dame des Fontaines, en La Brigue (Francia) (Fig. 11).

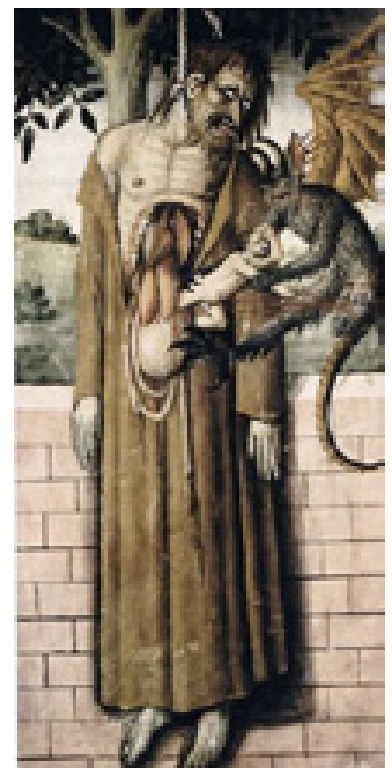

Fig. 11: Giovanni Canavesio, Suicidio de Judas (Notre-Dame des Fontaines, La Brigue, c. 1491)

Los detalles expresionistas de este fresco francés se presentan como muy reveladores, pero la imagen mostrada no resultaría en el momento de su ejecución tan excepcional como puede parecer hoy, sino que heredaba toda una tradición iconográfica de Judas ahorcado, con el vientre abierto, con las vísceras a la vista, expuestas como si se tratara de órganos genitales emasculados, y con el demonio arrebatando su alma — que

el suicidio de Judas ahorcándose. La actitud de Centurio, bravucón con espada, recuerda la del discípulo Pedro que, después de haber traicionado a Jesús tres veces, trata de enmendar su culpa con el gesto hiperbólico de cortar la oreja al soldado romano. Y Centurio, como Pedro, se ofrece a enviar al infierno al supuesto culpable de la muerte de los dos criados: "Pues sea assí; embiémosle [a Calisto] a comer al infierno sin confessión» (auto XVIII). El alguacil podría hacer acción de intentar abrirle el vientre con el filo del arma cortante, aunque parece más bien que va a decapitarlo, como ya han hecho con el otro criado que aparece en el grabado. 
surge como la de un niño en una operación de cesárea-, para conducirla a los infiernos. Lafran (2007: 167), en su magnífico trabajo sobre la muerte de Judas en las Biblias moralizadas (pues aparece la ilustración de su ahorcamiento en varias de las principales), confirma que mientras que las versiones textuales suelen seguir fieles la lectio del Evangelio de Mateo, la iconografía de Judas eviscerado - con las entrañas como aún vivas y temblorosas, a veces en forma de saco alargado - recogería, en cambio, la tradición de Hechos de los apóstoles. Poco a poco, a partir del siglo XIII, la evisceración se convierte en una suerte de canon. No se trata tanto de representar un suicidio, como de hacer encarnar un castigo, el castigo al avaro, puesto que las monedas son las vísceras del avaro. Y las monedas pueden asemejarse a las vísceras del traidor, como veremos más adelante en la leyenda-exemplum de Eneas avaro y traidor. Esas vísceras, tumefactas, hinchadas, en el centro del cuerpo, en el punto de fuga de la contemplación del lector o del espectador del fresco o el capitel, capturan su atención y golpean con violencia su imaginación. Al llegar la evisceración hasta los genitales se produce una mezcolanza viscosa y casi lúbrica entre los residuos de la codicia y los estragos de la lujuria. Una identificación la de Judas con la usura - propuesta ya desde al menos el siglo Iv, desde la Psychomachia de Prudencio (c. 392). ${ }^{37}$ En todo caso, la exposición de esas vísceras trata de sacudir su conciencia como lo harían los exempla en los sermones de los predicadores, como sugiere Weber (2002) en su trabajo sobre fuentes e interpretaciones del Judas de Friburgo (Fig. 43).

\section{Caídas, saltos y suicidios en La Celestina}

\subsection{Caídas accidentales y saltos mortales}

Las muertes tan repentinas y atroces de los dos criados han suscitado siempre discusión. Y no digamos, si les sumamos las otras caídas mortales en la obra, cruentas, llamativas y no menos controvertidas: la fortuita de Calisto y el suicidio premeditado de Melibea. La única muerte que parece que no sorprende, por haber sido gradualmente presentada y cumplir con ciertas razonables expectativas del lector, es el asesinato de Celestina. Pero las restantes son muertes desastrosas o «accidentales» en el sentido etimológico: son "caídas», saltos desesperados o tropiezos siempre inesperados. Sólo en un caso - la muerte de Melibea, la más compleja y abierta a la interpretación - estamos ante una precipitación al vacío deliberada y consciente. ${ }^{38}$

37.- Justamente, Poza Yagüe (2010), que se ajusta más que Robson (2001) a las representaciones hispánicas del ahorcamiento de Judas, las integra y relaciona con las personificaciones de la avaricia y usura.

38.- Véase, más adelante (n. 40), la mención a una bibliografía sucinta sobre el suicidio en la Edad Media, y el suicidio literario de Melibea. 
La escena de la muerte por suicidio de Melibea es probablemente la más profusamente ilustrada desde las primeras ediciones y también la que contaba para esas ilustraciones con más antecedentes figurativos: otros suicidios de mujeres. Pero también son ilustrados los otros crímenes de la obra, para los que se reservan xilografías propias más o menos originales en los programas iconográficos de muchas de las mejores ediciones del Xvi de La Celestina. Esas ilustraciones de momentos de acción dramática, pero también truculenta, tenían, sin negar los propósitos artísticos, otros comerciales evidentes, de intento de captación de clientes, llamando la atención de los lectores, que han sido bien estudiados. ${ }^{39}$ Se ilustran y condenan de manera clamorosa, a través esos programas de actuación editorial, además del autocastigo de la desperatio de Melibea, el castigo de la avaritia de Celestina, el castigo del homicidium de los criados (reflejando su crimen y posterior ejecución), y el castigo de un pecado más, la fornicatio, a través de la muerte de Calisto. Y una serie de objetos expresivos, de nítido valor iconológico, acompañan a los personajes en estos grabados, permitiendo identificar casi automáticamente dramatis personae (sin que haga falta la cartela correspondiente) y acciones: la casa, el muro, la puerta, la ventana, la escala, la espada, la saya, el rosario o bolsa de Celestina, etc. El complemento gráfico que suponían estas ilustraciones servía por un lado para satisfacer los gustos curiosos y truculentos del público, y por otro para fijar o reforzar la lectura ortodoxa y doctrinal de un texto que para muchos sería equívoco u oscuro, disconforme con esa ortodoxia, o por lo menos sorprendente. Y tal vez pudiera darse una gradatio secuencial, haciendo que la última muerte - y el último grabado- fuera el del castigo más grave para el más reprobable pecado: el suicidio.

Pero vayamos primero a las caídas atroces anteriores. Tras haber asesinado a Celestina, Sempronio y Pármeno saltan desde unas ventanas de la casa. Uno tras otro:

Sempronio. ¡Saltemos destas ventanas, no muramos en poder de la justicia!

PÁrmeno. Salta, que tras ti voy. (auto XII, p. 261)

La decisión de lanzarse al exterior desde una altura considerable resulta muy precipitada, pero se justifica porque han explicado antes que «carga mucha gente» $\mathrm{y}$ "viene el alguacil» (Sempronio), "está tomada la puerta» (Pármeno), y en consecuencia los criados no quieren morir «en poder de la justicia» (Sempronio) (XII, 261). Sin embargo, las fatales secuelas traumáticas de los saltos parecen exageradas o bastante improbables, si es que realmente quedan «cuasi muertos», como dirá luego Sosia: «saltaron

39.- Para las ilustraciones de La Celestina, a partir de los trabajos fundamentales de Griffin (2001) y Snow (1987 y 2005), una bibliografía esencial viene recogida en los estudios recientes de Fernández Rivera (2020), Jiménez Ruiz (2020), Romero (2020) y Saguar (2020), todos ellos consultables como video-artículos publicados del I Congreso del CELPYC. 
de unas ventanas muy altas por huir del alguacil, y así cuasi muertos les cortaron las cabezas, que creo que ya no sintieron nada» (XIII, 267).

La casa de Celestina es sin duda un espacio simbólicamente maldito, herméticamente cerrado que sólo abre el teatro de su tragedia por las ventanas, que en realidad muestran grietas o rendijas de falsa liberación. Habla Sosia de "unas ventanas muy altas», pero esa altura, para resultar "cuasi muertos» de la caída, tendría que haber sido como la de la torre desde donde se arroja Melibea al vacío, o al menos la de un segundo piso, y aun así la distancia del suelo no sería tanta, contando con casas de techos bajos como eran las de la época. Los grabados, obligados apretary reducir las distancias verticales para encuadrar con una cierta proporción a varios personajes en una o dos secuencias, no nos pueden servir de reflejo totalmente fiel, pero sí aportan testimonios esenciales para entender cómo se imaginaban esas auto-defenestraciones. De hecho, lo que se deduce del relato de Sosia, que es el más completo del suceso, es que el salto de al menos uno de ellos, no sabemos si Sempronio o Pármeno, forzosamente tendría que haber sido de cabeza, rompiéndose los "sesos", como efectivamente vemos que muestran varios grabados, puesto que literalmente se abre el cráneo:
El uno llevaba todos los sesos de la cabeza de fuera sin ningún sentido, el otro quebrados entramos brazos y la cara magullada, todos llenos de sangre, que saltaron de unas ventanas muy altas por huir del alguacil, y así cuasi muertos, les cortaron las cabezas, que creo yo que ya no sintieron nada. (XIII, 267)

Pero actuar así, tirándose de cabeza por una ventana alta al vacío, por muy apremiados que se vieran por los alguaciles, era hacerlo contra toda razón. Aunque la situación desesperada y extrema nuble la razón a los criados, es difícil arrojarse de ese modo, ni siquiera instintivamente. De haber caído o saltado de pie, tratando de descolgarse, como habría sido mucho más lógico, el primer saltaventanas se habría roto, como le ocurre al segundo criado ("el otro»), una pierna, la cadera o la espalda — "quebrados entramos brazos y la cara magullada»-, pero difícilmente la cabeza ("los sesos de la cabeza»).

El texto no da más explicaciones sobre ese salto de cabeza. Y, sin embargo, de esta manera, tirándose de cabeza desde una ventana ligeramente elevada, imaginan la caída y descalabro de al menos el segundo de los criados mencionados por Sosia varios de los editores que incluyeron grabados para la escena, como los de Valencia, 1514 (Fig. 1) y Sevilla, 1518-1520 [1502] (Fig. 2), o, en la misma línea que éstos, Sevilla, Pedrezano, 1523 (Fig. 12). ${ }^{40}$

40.- Sosia ha especificado, antes, al principio del auto XIII, al contarle la escena a Tristán, que aunque «sin sentido iban» (los dos), «el uno, con harta dificultad» le había dirigido la mirada e interrogado con los ojos, en silencio, «en señal de triste despedida» (266). Elicia, presente 


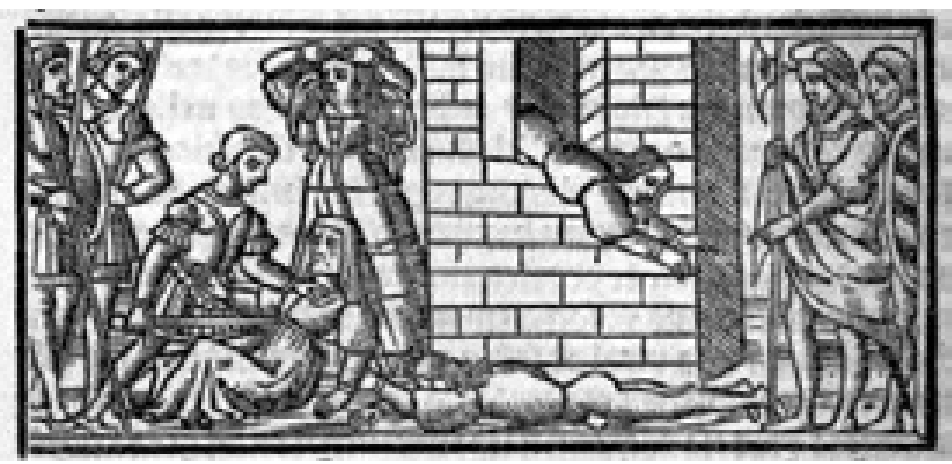

Fig. 12. Salto de los criados (Sevilla, 1523)

Este último, el de Sevilla, 1523, con muy parecida disposición visual de elementos que el grabado del salto al vacío de Melibea (Fig. 13).

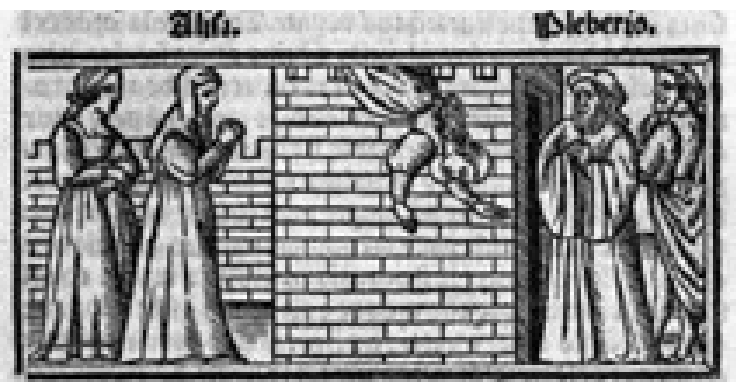

Fig. 13. Salto de Melibea (Sevilla, 1523)

\subsection{Salto y suicidio de Melibea}

Dada la similitud dispositiva de elementos que aparecen en estos dos saltos tan dispares (el de la huida y el del suicidio), convendría que tuviéramos presente el limitado repertorio de modelos iconográficos con que se contaba para reflejar esta acción tan excepcional. Para ello, y aunque nos queramos centrar en el salto de Pármeno, será necesario remontarnos al que, entre las dos, contaba con más precedentes: el salto suicida de Melibea. Dentro del clima de criminalización sin paliativos del suicidio a lo largo de toda la Baja Edad Media, el acto resolutivo de Melibea en La Celestina no podía tener la mínima justificación moral, como ha puesto de manifiesto la crítica. El tema de la muerte de Melibea ha recibido detallados y agudos acercamientos en los últimos años, entre los que destaca-

también en la escena (horrorizada por los hechos, como la muestran los grabados) confirma luego la gravedad del descalabro: «por huir de la justicia, que acaso pasaba por allí, saltaron de las ventanas y cuasi muertos los prendieron» (XV, 289). 
remos los trabajos fundamentales de López-Ríos (2005), Lacarra (2007) y Álvarez (2017). ${ }^{41}$ Pero es necesario recordarla aquí específicamente como culminación de las otras caídas atroces y cierre dramático de la carrera de crímenes en la obra.

Marías Martínez, en su contribución al estudio del suicidio en novela áurea de autoría femenina (María de Zayas) y masculina (Juan Pérez de Montalván), habla de los principales paradigmas tradicionales (el clásico, el bíblico y el medieval) de representación del suicidio femenino:

El clásico femenino muestra una división entre los suicidios heroicos de Porcia (carbones ardiendo) o Lucrecia (cuchillo) de fuentes históricas y morales; y los pasionales de origen literario trágico (Antígona, Fedra) o mitológico, sobre todo ovidianos (Heroidas). Estos tendrían un cariz más negativo por su vínculo con el descontrol de los apetitos (no reflexión), e incluirían junto al cuchillo, métodos menos dignos y heroicos como el ahorcamiento o la muerte por precipitación. (2013: 263-268)

Álvarez, teniendo presente este paradigma, contrapone más drásticamente la raigambre clásica a la bíblica, que presenta una casuística casi exclusivamente masculina. Y entre esos suicidios bíblicos destacará el único suicidio que aparece en el Nuevo Testamento, el de Judas:

Del paradigma clásico, tamizado o no por fuentes medievales, provienen muchas de las posibles fuentes del suicidio de Melibea [...]: Hero (Ovidio, Museo), Dido (Ovidio, Crónicas), Filis (Ovidio), Fedra (Séneca) [...]. En cuanto al bíblico, es sobre todo masculino (Sara no se llega ahorcar), con métodos y motivos diversos, y solo positivos los de Sansón, Eleazar y Racías. El único del Nuevo Testamento es el ahorcamiento de Judas, que in-

41.- Estos tres críticos suelen partir de los estudios principales sobre el suicidio en la Antigüedad y la Edad Media europea, especialmente de los ya mencionados de Murray (2000) y Brown (2001), y a la hora de tratar el suicidio de Melibea, se remontan a los trabajos clásicos de Lida de Malkiel (1962), Heugas (1973), Ayerbe-Chaux (1978), entre otros pocos. Lacarra, que ya había hecho una aproximación muy personal al personaje y a las implicaciones de su decisión última (1990), más tarde (2007) desarrolla por extenso una magnífica presentación del tema del suicidio, a partir de su tratamiento legal, canónico y civil, a la que sigue una síntesis de los principales casos de suicidios literarios hispánicos, agrupados como suicidios honorables y reprobables. López-Ríos (2005) y Álvarez (2017) se centran ya específicamente en el caso de Melibea, alcanzando conclusiones que en gran parte se complementan y nos eximen de la necesidad de entrar en aspectos concretos perfectamente explicados e ilustrados en sus aproximaciones. Véase también Sanmartín (2005), quien destaca el espectáculo de lo macabro — no exento de morbosa sensualidad - en el suicidio de Melibea; y Mier Pérez (2017), quien compara la muerte violenta de Melibea con los suicidios de otros personajes femeninos del teatro renacentista: Plácida (Encina) y Serafina (Torres Naharro). 
fluirá enormemente en el discurso escolástico de la responsabilidad humana y los pecados mortales (desperatio, castigo post-mortem). (2017: 319)

Álvarez concuerda con Murray y Brown en que en la Edad Media las muertes suicidas son castigos quirúrgicos absolutos, sin concesión ni clemencia, sanciones aleccionadoras máximas para unos ejemplos vitales que se consideraban abominables y reprobables sin remisión. Sanciones no exentas de deleitación morbosa en lo macabro, una característica de la sociedad bajo-medieval que ya destacaba Huizinga, al contrastar paradójicamente esa brutal carencia de compasión por el otro, generalizada en el otoño medieval, con la caritas que predicaba el cristianismo. Sin embargo, como sintetiza perfectamente Sanmartín: "La lección cristiana de lo macabro (el memento mori) puede volverse así una invitación a la significación inversa (memento vivere). Y la moral del castigo puede quedarse un instante detenida en la mirada consternada por el encantamiento que ejerce el erotismo mórbido que recorre la cultura macabra» (2005: 121).

Centrándonos en el suicidio de Melibea, y atendiendo a las diferencias de espacios respecto a las "caídas» anteriores (las de Sempronio, Pármeno y Calisto), podríamos recordar algunas consideraciones sobre el simbolismo de la altiva torre de la casa paterna desde donde se arroja. La torre que se eleva al cielo (en contraste con la tierra asentada sobre el subsuelo infernal) ha sido interpretada como metonimia de una ambición desmesurada de poder, de una desviación del orden constituido y de un deseo malsano de elevación fuera de toda razón, además de efímero. Significaría, como también se ha visto, la subida a lo alto en la Rueda de la Fortuna, desde donde la caída o precipitación autoinfligidos serán más graves y acusados (Matthies, 2000). Sin embargo, también otros espacios en alto, en edificios más vulgares que la noble torre, pueden metaforizar esa caída en personajes de clase social inferior. En todo caso, la balaustrada de la rica torre burguesa o la ventana de la humilde casa plebeya se abren igualmente como hendiduras por las que se escapará, como una fisura que no se puede cerrar, el vicio indomable.

En ese contexto alegórico, también el árbol entraría dentro de los loci elevados. Álvarez ha subrayado como valor simbólico la sustitución del árbol de suicidio de Judas por la torre de suicidio de Melibea: «Mediante concurrencia visual, ese "ahorcarse de la torre" de Melibea fortalecía la asociación de su muerte con el peor pecado: la desesperación. Esta, dentro del discurso teológico prevalente equivalía a falta de fe, de esperanza en la salvación y de incapacidad para reconocer a Dios [...]» (2017: 325).

Como descensos demoníacos simbólicos, las caídas medievales basculan entre la torre -o el árbol- en lo alto y el pozo en lo bajo. Cae Lucifer y caen los condenados, como caen Ícaro y Faetón, ambiciosos y soberbios, rebeldes también al padre, en sus respectivos vuelos aciagos. 
Estos dos últimos se precipitan desde los cielos al mar. Pero Lucifer cae a las llamas (Fig. 14), las mismas llamas que acompañarán y subrayarán los efectos de las caídas de Dido (Fig. 17).

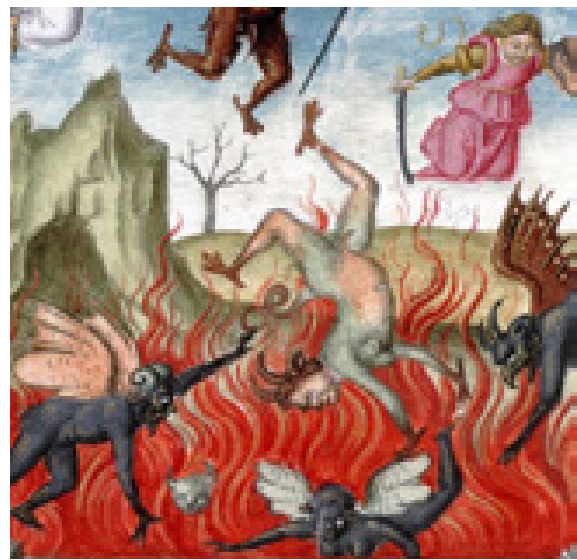

Fig. 14. Fall of Lucifer, Offices, Italy 1519

(San Marino, CA, Huntington Library, HM 1046, fol. 245v)

O Lucifer cae al pozo, el espejo invertido de la torre (la torre de Dido y Melibea), como en el Infierno de Dante, ilustrado a finales del siglo Xv (Fig. 15).

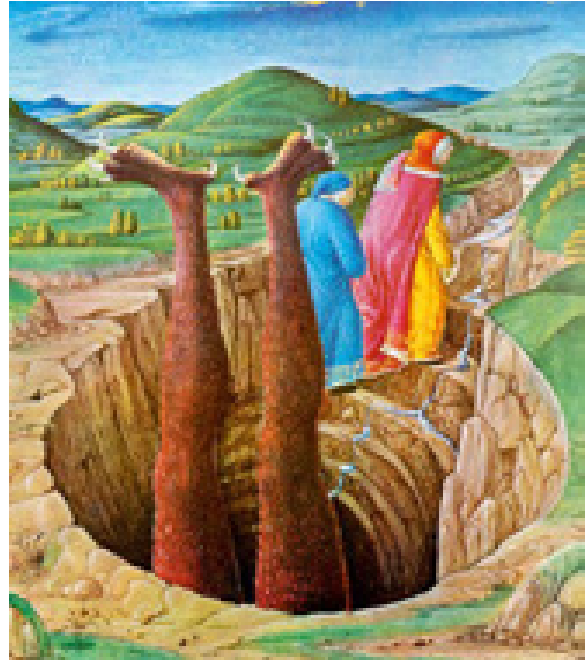

Fig. 15. Dante, Divina Comedia (Ferrara, 1474-1482).

Roma, Biblioteca del Vaticano, Ms Urb. Lat. 365, fol. 95v. 


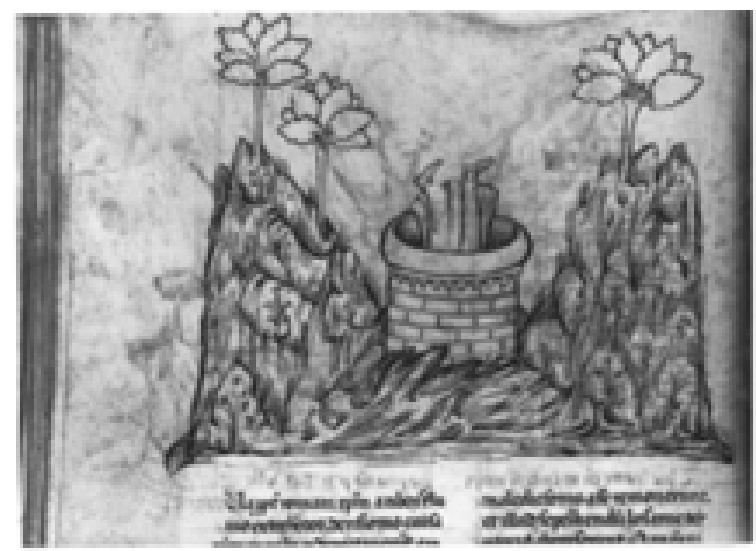

Fig. 16. Pilato arrojado a un pozo en los Alpes. Milán, Biblioteca Ambrosiana, MS Lat. 58 Sup., fol. 68.

Reprod. por Murray (Plate 12b)

La leyenda popular de un personaje no angélico ni demoníaco, sino tan humano como Judas, el personaje de Poncio Pilato - pecador de envidia y no de traición-, que se suicida al saber que el Emperador tiene previsto matarlo, guarda algunas similitudes con la de Judas, a partir igualmente de las versiones que constata la Leyenda dorada (Murray, 2000: 239-243). Pilato, cuando es ilustrado en esa leyenda, cae como Lucifer, cuando es arrojado a un pozo en los Alpes (Fig. 16).

Son ejemplos extremos y ejemplos de personajes masculinos, amparados por versiones bíblicas o legendarias, canónicas o apócrifas. Ahora bien, a la hora de establecer antecedentes textuales, pero también gráficos, para el suicidio de Melibea, parece que el marco genérico de la ficción sentimental es el que más amparo y protección ofrece, puesto que es ese género (y luego el de la novela pastoril) el que aborda el tabú del suicidio masculino y femenino con mayores márgenes de libertad. Marías Martínez, a partir de Lida de Malkiel (1952, 1962 y 1974) y de otros críticos, aduce, para Melibea y otros suicidas, semejanzas con el paradigma clásico femenino en los suicidios masculinos de Ardanlier en Siervo libre de amor (1439), Leriano en Cárcel de amor de Diego de San Pedro (1492) y Grisel de Grisel y Mirabella de Juan de Flores (1495).42 Y precedentes femeninos más concretos del suicidio de Melibea, además de la Fiammetta de Boccaccio, salvada in extremis por la nodriza (que ya apuntaba Lida de Malkiel 1962: 447), serían los de la Oriana del Amadís primitivo, la Camar de Curial y Güelfa o la Mirabella de la ya citada obra Juan de Flores, que se precipita desde las alturas para ser despedazada 
por los leones al haber perdido la virginidad con Grisel, suicidado previamente arrojándose a las llamas. ${ }^{43}$

Moreno (2007: 21-30), en un revelador artículo, mostró cómo la imagen del suicidio de Dido en el Ms. 3995 de la BNE (s. Xv) de los Castigos del rey Sancho (Fig. 17) pertenecía a un universo manuscrito visible, con variantes de escuela o época, en precedentes miniados europeos que incluyen la versión de la heroína de Cartago asomada vertiginosamente a una torre, haciendo destacable una acusada verticalidad. ${ }^{44}$

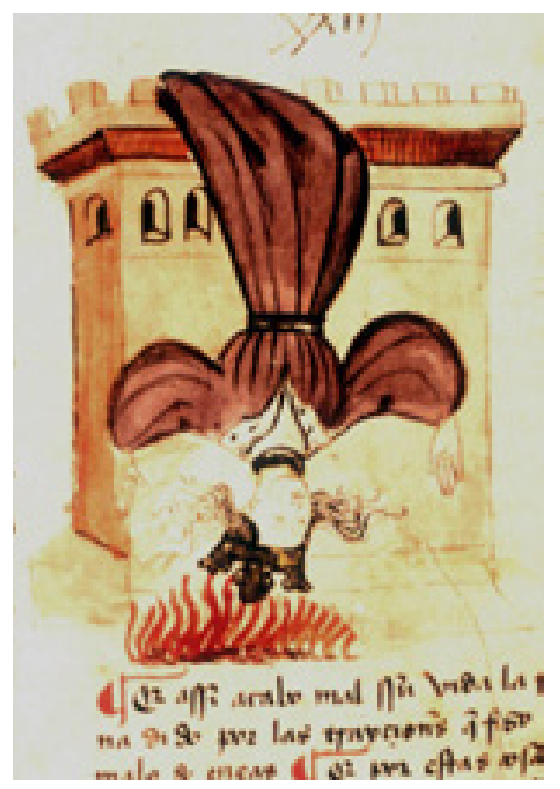

Fig. 17. Castigos del rey Sancho, BNE, ms. 3995, fol. 66v.

El suicidio de Dido cobraba más espectacularidad y resultaba más fiel a los textos originales si se ilustraba en movimiento, en esa caída vertical, boca abajo, mostrando con el vuelo de las mangas del vestido una cruz invertida. No tiene los brazos extendidos hacia adelante, característica de todas las imágenes que vamos a repasar a partir de ahora. Había otras alternativas gráficas para el suicidio de Dido, como la inmolación estática en pira - el mismo fuego purificador con que acoge la tierra, limpiándolo, el cuerpo impío-que nos ofrece la Suma de virtuoso

43.- Álvarez añade a estos antecedentes, reconociendo su posible menor incidencia, el modelo hagiográfico de Santa Pelagia de Antioquía, lanzándose desde la azotea para evitar ser deshonrada por los soldados romanos. Pero no he podido hallar testimonio gráfico de esta muerte de la mártir.

44.- Véase Haro (2012 y 2014) para la comprensión general del proyecto iconográfico del códice miniado de los Castigos del rey Sancho. 
deseo (Fig. 18). ${ }^{45} \mathrm{O}$ el suicidio clásico, con la espada, como el repetido de Lucrecia, que adopta también, de nuevo, la reina Dido, por ejemplo en la bella ilustración del ms. Harley 4867 de la British Library, que contiene la traducción francesa de Octavien de St. Gelais de las Heroidas de Ovidio (Fig. 19). ${ }^{46}$

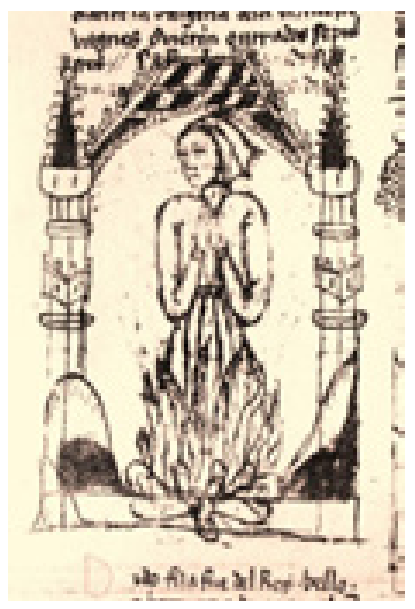

Fig. 18. Suicidio de «Dido, fija fue del Rey bello». Suma de virtuoso deseo, BNE, ms. 1528, fol. 69v.

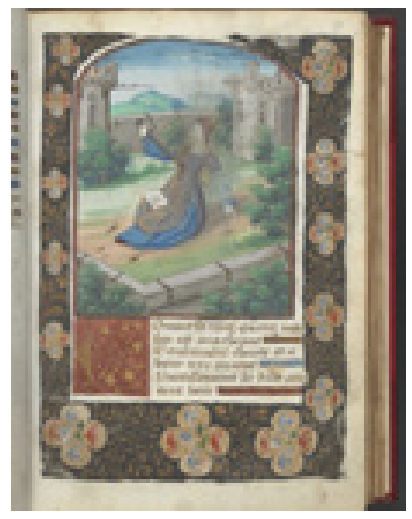

Fig. 19. Suicidio de Dido. Traducción francesa de las Heroidas de Ovidio. Ms. Harley 4867, British Library.

45.- Se trata de la adaptación histórica de algunas de las glosas del marqués de Santillana a sus Proverbios, adaptación que realiza la Suma de virtuoso deseo. Véase Beltrán (1997 y 2014). La misma Suma recoge también una ilustración con el suicidio de Lucrecia con la espada (BNE, ms. 1528, fol. 56v.).

46.- Se trata del manuscrito con la traducción francesa de las Heroidas a cargo de Octavien de St. Gelais, procedente del centro de Francia (¿París?) y que contiene 21 bellísimas ilustraciones como la que mostramos. Véase: $<$ http://www.bl.uk/catalogues/illuminatedmanuscripts/record.asp?MSID $=4667 \&$ CollID $=8 \& N S t a r t=4867>$. 
Esas variantes en el suicidio se repiten con las caídas de las heroínas y luego con los personajes femeninos. Las caídas desde la altura podrán ser de una mayor o menor verticalidad u horizontalidad. Dependiendo de la perspectiva que se adopte para incluirlas en el conjunto de la imagen, la heroína se arroja (Fig. 20), o se asoma (Fig. 21), o se descuelga de la torre, siempre de cabeza, como sucederá con Melibea (Figs. 22-26). Valgan como ejemplo algunas de las ilustraciones antiguas de otro de los antecedentes más plausibles entre los propuestos para el suicidio de Melibea: el suicidio de Hero, tras el ahogamiento de Leandro (Figs. 20 y 21). Normalmente, cuando hay espacio visual de una amplitud suficiente, las caídas son más estrepitosas, dramáticas y llamativas, al ir dibujadas con mayor verticalidad. Así, el maestro ilustrador de L'Épitre Othéa de Christine de Pizan (ms. Français 606 de la BNF) representa la caída de Hero lanzándose tan grácilmente como haría en su ascenso a los cielos el ánima de un moribundo. ${ }^{47} \mathrm{~A}$ la inversa aquí, el cuerpo desciende, en vez de ascender, igualmente volátil, para poder abrazar y fundirse en las aguas con el cuerpo recién ahogado de su amado Leandro (Fig. 20).

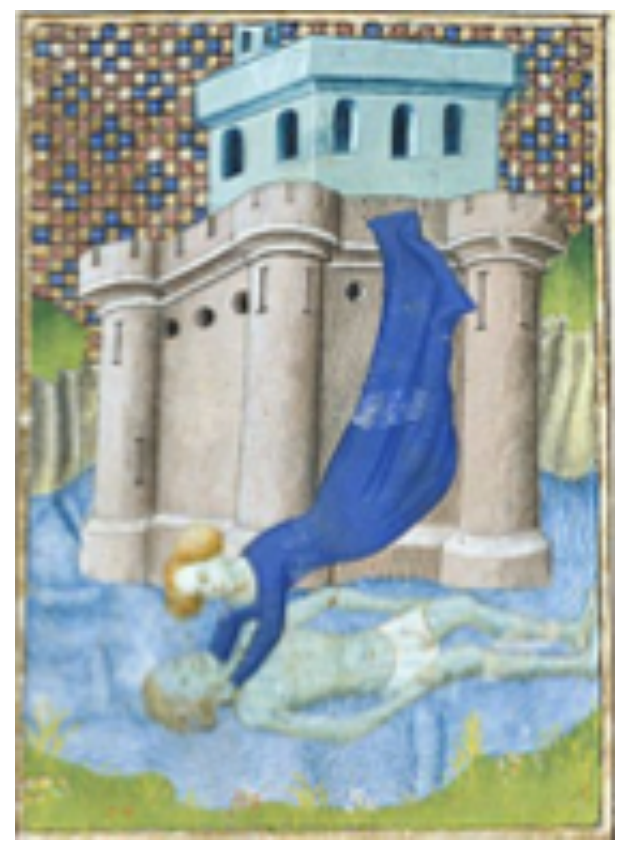

Fig. 20. Hero lanzándose sobre Leandro.

L'Épitre Othéa de Christine de Pizan

47.- El ms. de L'Épitre Othéa de Christine de Pizan se puede consultar en Gallica: <https:// gallica.bnf.fr/ark:/12148/btv1b52000943c/f28.image> 


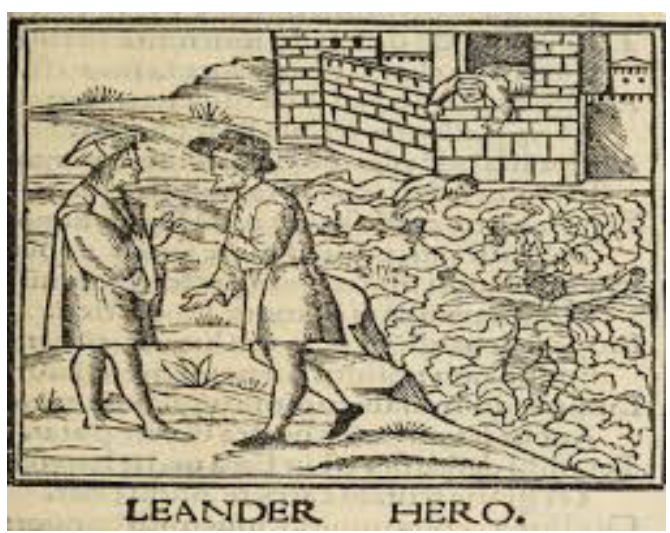

Fig. 21. Suicidio de Hero en las Heroidas (1510). Apud Álvarez (2017: 322)

Este vuelo estilizado y grácil de Hero hacia Leandro podía tener un precedente en la representación de Simone Martine que examinaremos poco más adelante, a propósito de la ilustración de un milagro. Con menos espectacularidad, pero más cercanas a los dibujos de La Celestina, encontraremos las ilustraciones del suicidio de la misma Hero en las ediciones venecianas de las Heroidas de 1516 y 1520 (Fig. 21), cuyos modelos, algo anteriores, han sido aducidas razonablemente por López-Ríos (2005: 310) y Álvarez (2017: 321) como antecedentes de los primeros grabados con la caída de Melibea.

Es este grabado del suicidio de Hero, en efecto, el dibujo más parecido que hallamos - si descontamos la miniatura del ms. de Castigos del rey Sancho alegada por Moreno- para los grabados del suicidio de Melibea en las ediciones de Valencia, Jofré, 1514 (Fig. 22), ${ }^{48}$ Roma, Silber, 1515 [colofón Sevilla, Polono, 1502] (Fig. 23), ${ }^{49}$ Sevilla, Pedrezano, 1523-Venecia, 1534 (Fig. 24) ${ }^{50}$ o Augsburgo, Steiner, 1534 (Fig. 25). ${ }^{51}$ En ediciones posteriores, como las de Valencia, Navarro 1575 (que parece retrotraerse

48.- Tipobibliografía valenciana de los siglos xv y xvi, base de datos dirigida por José Luis Canet: $<$ https://parnaseo.uv.es/imprenta/publicacion/presentacion.html\#>.

49.- Cromberger? e ilustrador anónimo, «Ilustración segunda del acto XX de la edición de Roma: Marcelo Silber, 1515 (colofón Stanislao Polono, Sevilla, 1502)», CelestinaVisual.org, consulta 25 de septiembre de 2020: <http://celestinavisual.org/items/show/463>.

50.- Pedrezano, Juan Bautista e ilustrador anónimo, «Grabado del acto XXI de la edición de Sevilla (1523)», CelestinaVisual.org, consulta 25 de septiembre de 2020: <http://celestinavisual. org/items/show/300>.

51.- Véase Carmona $(2007,2012)$. Hans Weidtz, «Grabado del acto XX de la edición de Augsburg (1520)», CelestinaVisual.org, consulta 25 de septiembre de 2020: <http://celestinavisual.org/items/show/335> 
al grabado de Jofré, 1514) (Fig. 26) 52 o Salamanca, Renaut, 1590 (que sigue a las ediciones sevillanas), continuarán la misma línea, sin importantes variaciones.

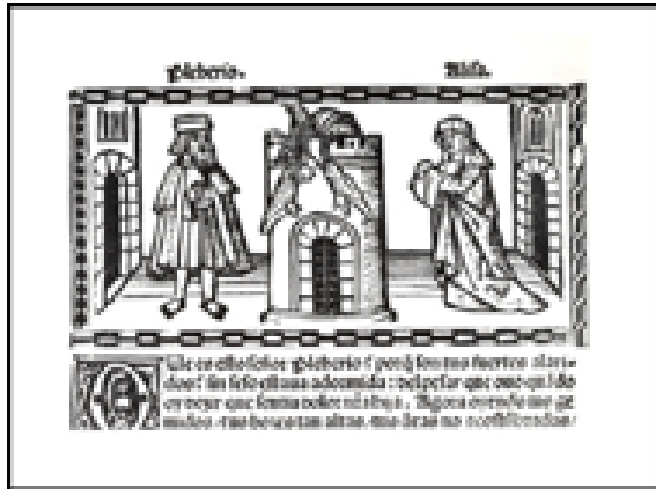

Fig. 22. Suicidio de Melibea (Valencia, 1514)

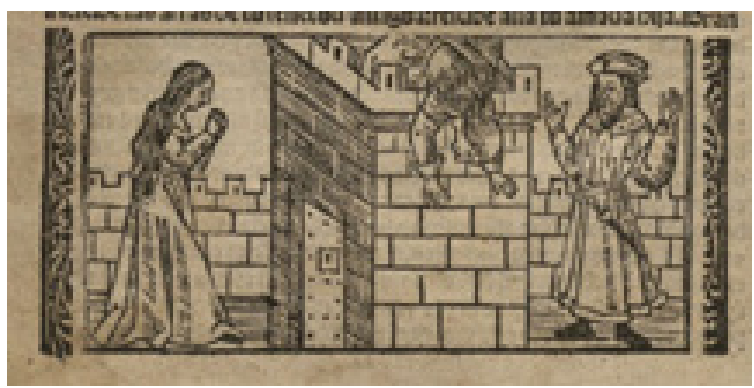

Fig. 23. Suicidio de Melibea (Sevilla, 1502)

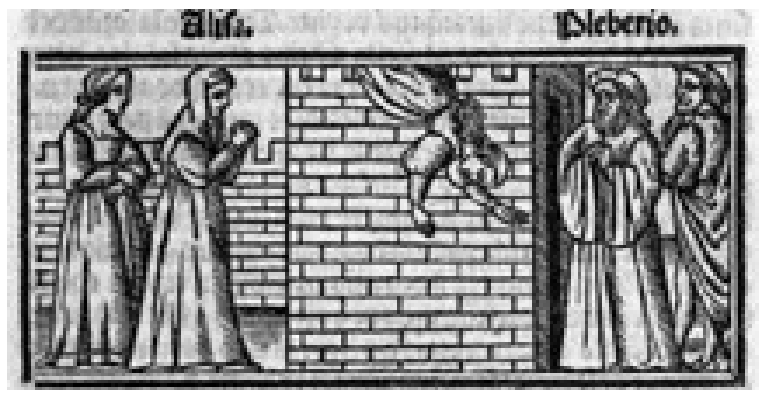

Fig. 24. Suicidio de Melibea (Sevilla, 1523; Venecia, 1534)

52.- Tipobibliografía valenciana de los siglos XV y XVI, base de datos dirigida por José Luis Canet: $<$ https://parnaseo.uv.es/imprenta/imagenes/Imgs/870_Grabados_grabado-2.jpg>. 


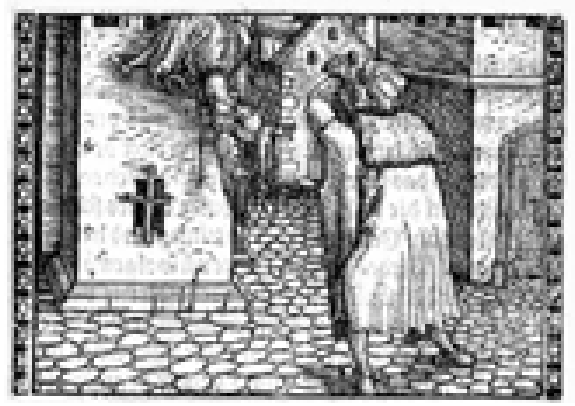

Fig. 25. Suicidio de Melibea (Augsburgo, 1534)

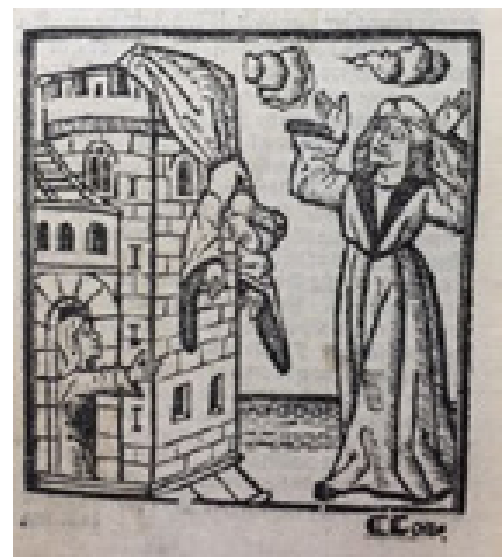

Fig. 26. Suicidio de Melibea (Valencia, 1575)

No he visto nunca aducido como precedente del de Melibea el suicidio femenino que a continuación comento, desde lo alto de lo que podría ser un palacio con torre, captado entre la verticalidad y la horizontalidad. Se trata de la ilustración a la novella del Decamerón, IV, 9, presentada en el ms. Français 239 de la BNF, que recoge la traducción francesa de Laurent de Premierfait. El tiempo detenido corresponde en este caso al momento en que se arroja al vacío la mujer de Guiglielmo Rossiglione, amante de Guiglielmo Guardastagno, amigo del primero, ambos nobles de Provenza (el segundo correspondería al famoso poeta provenzal Guillem de Cabestany). El marido, una vez descubierto el adulterio, asesina al amante, le saca el corazón y se lo hace preparar condimentado a su mujer, revelándole a continuación el contenido de lo que había comido. Es cuando la mujer, desesperada, se tira por la ventana (Figs. 27 y 28). ${ }^{53}$

53.- Boccaccio, Décaméron, trad. de Laurent de Premierfait (1401-1500). BNF, Français 239, fol. 137v. <https://gallica.bnf.fr/ark:/12148/btv1b7100018t/f360.image.r=\%20Decameron.zoom>. 


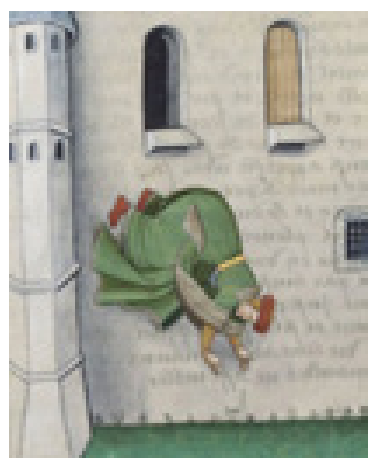

Fig. 27. Detalle de la Fig. 28.

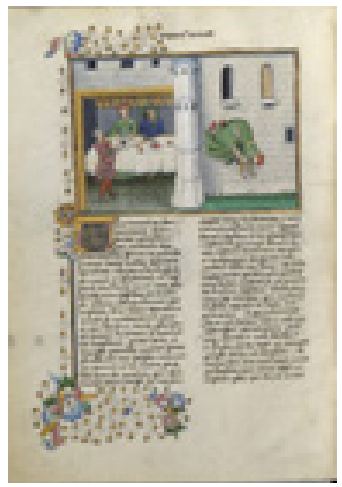

Fig. 28. Boccaccio, Décaméron, BNF, Français 239, fol. 137v.

Y me parece interesante confrontar otra imagen de caída, que correspondería en este caso al insólito intento de suicidio de un niño. Lo aporta Robson (2001, I: 185-186) y se trata del milagro del hijo del notario romano, reproducido en un fresco del transepto norte de la Basílica inferior de San Francisco en Asís, atribuido a Giotto o a su escuela (c. 1308-1311) (Figs. 29 y 30). El niño, que se ha visto forzado a quedarse solo en casa mientras su madre iba a la iglesia, se tira por una ventana. No se trata de un accidente, sino de un acto de desesperación del niño, por lo que los críticos lo conceptúan siempre como suicidio. ${ }^{54}$

54.- Robson: «The texts explain how, shortly after the tragedy, a passing Franciscan friar arrives on the scene and asks the parents whether they believe in St. Francis's power to raise their son from the dead, 'through the love he always had for Christ, who was crucified to give life back Io all'. The artist shows the friar and his companion surrounded by the towns people and clergy in supplication. The child is seen restored and back on his feet, both hands raised in thanksgiving. The pose of the boy's mother (wearing red, she is shown twice: looking up and raising her arms towards heaven), is a gesture of hope, in contrast to the falling child behind her» (2001, I: 186). El milagro lo incluye Buenaventura de Fidanza en su biografía de Francisco de Asís, aunque la fuente del pintor pudo ser otra, como sugiere Robson. 


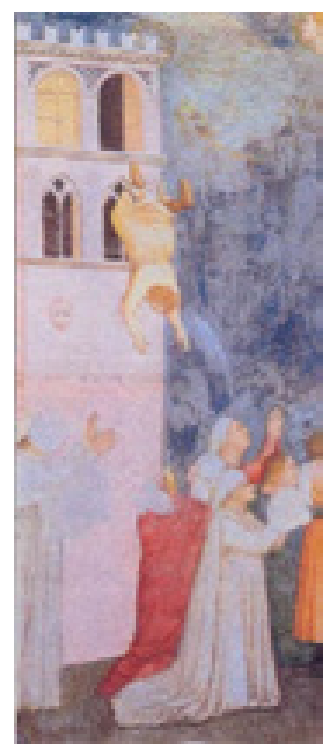

Fig. 29. Detalle del Milagro de la Fig. 30

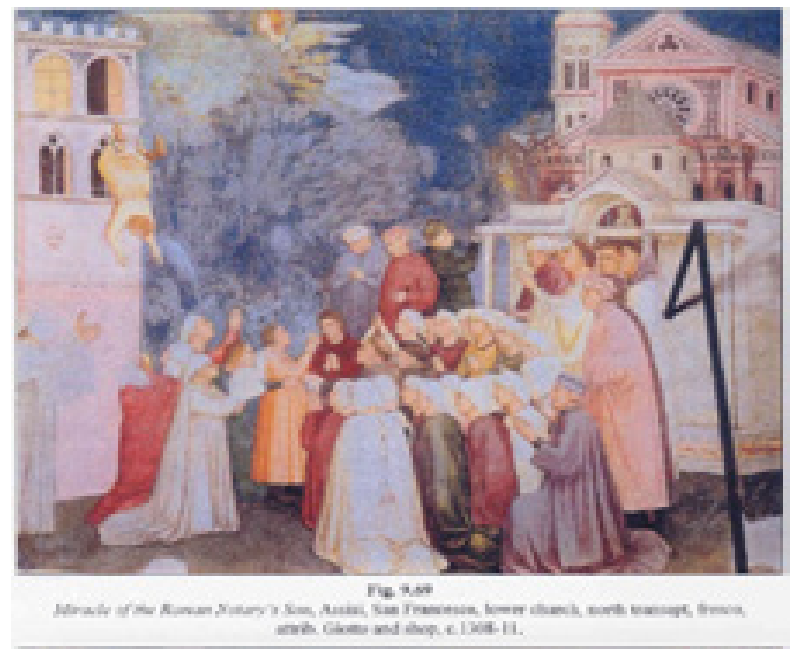

Fig. 30. Giotto, Milagro del hijo del notario romano. San Francisco en Asís (c. 1308-1311)

El milagro de la detención del caído desde una altura considerable tenía precedentes y continuaciones como tema. Su precedente iconográfico más notable podría identificarse con esta imagen de Simone Martini (Fig. 31), en la que el Beato Agostino Novello, con tan grácil vuelo co- 
mo el que observábamos que Hero desplegaba para rescatar a Leandro (Fig. 20), salva in extremis a un bebé caído desde la altura de un balcón: ${ }^{55}$

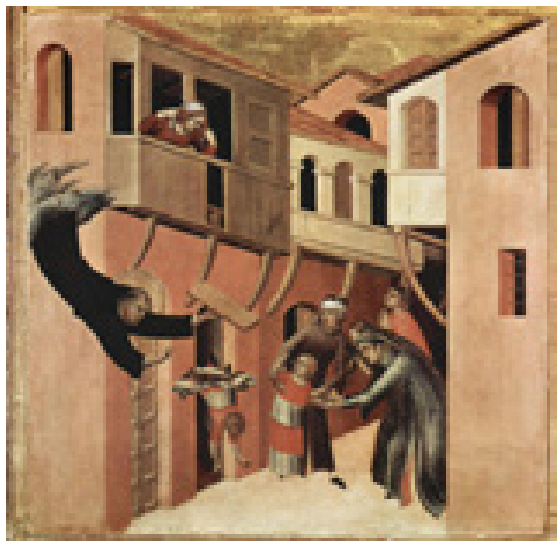

Fig. 31. Tabla inferior del políptico del Beatro Agostino Novello. Siena, Pinacoteca Nazionale (c. 1328).

Milagro y caída tendrían su repercusión en el milagro del albañil caído del andamio, uno de los más populares de san Vicente Ferrer. El tema de la detención del caído es el mismo y la figuración, en cuadros como el siguiente, ya muy posterior, de la escuela véneta de 1700, se asemeja también (Fig. 32):

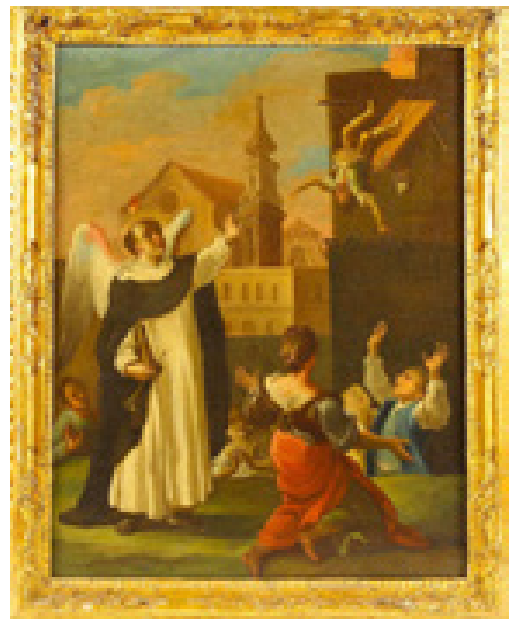

Fig. 32. Milagro de san Vicente. Escuela véneta del 700

55.- Debo la información sobre la tabla de Simone Martini y la de san Vicente Ferrer, que comento a continuación, a los extensos conocimientos en el tema y a la generosa colaboración en este apartado de Óscar Calvé. 
Matthies (2000: 1297) propone como modelo de ilustración una carta, el arcano 16 del Tarot ${ }^{56}$ que remonta a las ilustraciones del siglo xv del Tarot de Visconti-Sforza, con dos figuras humanas, constructores o albañiles (Fig. 33).

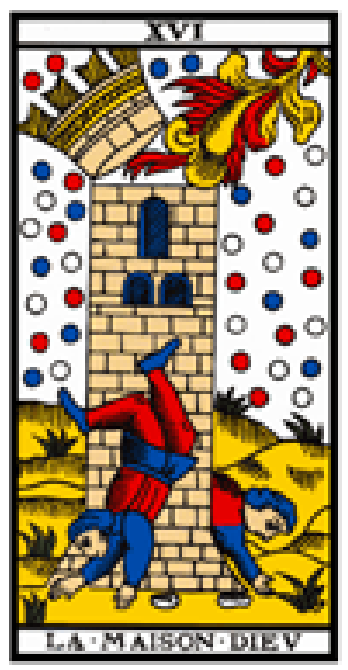

Fig. 33. La casa de Dios. Figura del Tarot

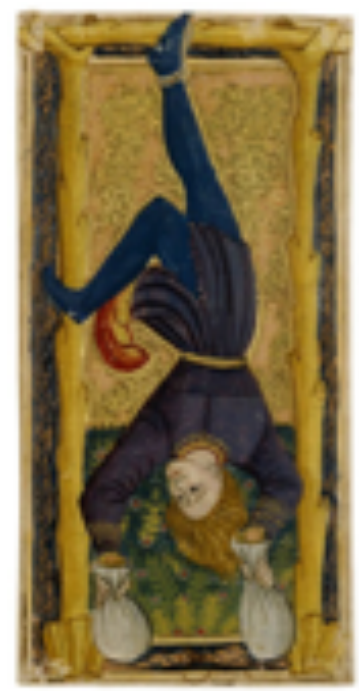

Fig. 34. El colgado. Figura del Tarot

56.- <https://alchetron.com/Visconti-Sforza-tarot-deck\#visconti-sforza-tarot-deck-93016c8f3fa1-4e8c-a08b-2e4a6f26396-resize-750.jpeg>. 
Y, en efecto, con la figura de Judas ahorcado, con su bolsa o bolsas de dinero, se vincula también el arcano 12 del Tarot (Fig. 34).

Más extrañas todavía, pero con el mismo movimiento articulatorio de brazos y piernas, son las ilustraciones de la muerte de Enus en los Isopetes historiados. El suicidio de Enus, desde el acantilado, aparecía ya - confundido con el asesinato del propio Esopo- en alguno de los manuscritos del Esopo de Aviano, como en esta imagen de la traducción al francés de las Fables, a cargo de Julien Macco, magníficamente iluminada (Fig. 35) ${ }^{57}$ :

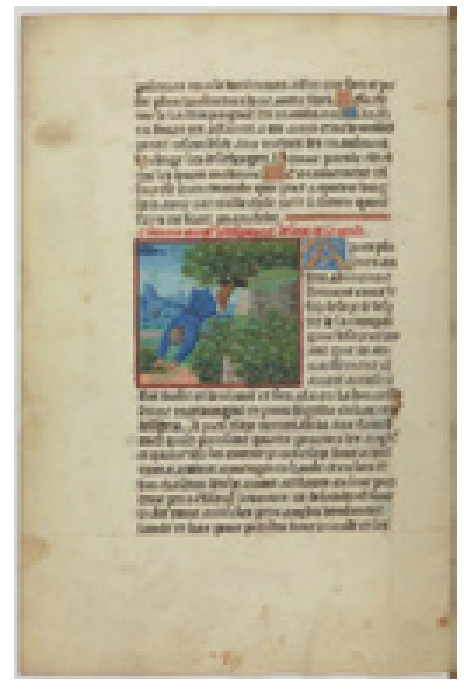

Fig. 35. Aviano, Aesopus, BNF, Smith-Lesouëf 68, fol. 20v

Enus, el hijo adoptivo de Esopo, es un traidor que acusa falsamente a Esopo. Y que, al poco, desesperado por su imperdonable falta, se arrojará desde una alta torre abajo. Sin necesidad de atender a los detalles de la creación de este personaje, Enus, su final parece trazado a imagen y semejanza del de Judas. ${ }^{58}$ En la versión castellana de La vida de Ysopo (Valencia, Juan Jofré, 1520) se explicita ese suicidio, acompañado por su correspondiente ilustración (Fig. 36):

Con estos et con otros muy muchos amonestamientos Isopo envió de sí a Enus, el cual falsamente acusó a él. E dende a poco, desesperando, de una torre alta abajo se echó; et así, como malo que era, desaventuradamente acabó su vida. (Romero, 2001) 


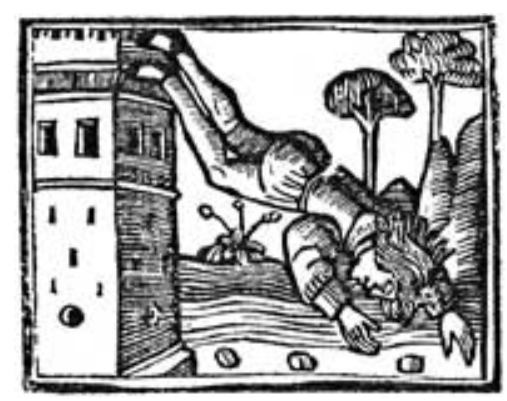

Fig. 36. Suicidio de Enus, en la La vida de Ysopo (Valencia, Juan Jofré, 1520)

Esta ilustración (Fig. 36), con todas las diferencias obvias (el edificio, el cuerpo completo) es la más parecida a la de la caída de Pármeno, en la edición de La Celestina de Valencia, 1514 (Fig. 1), que podemos localizar. Es claramente, sin embargo, el suicidio de un traidor (Enus / Judas) y no el salto de un huido de la justicia. El impresor Juan Jofré pudo haber utilizado para este grabado de 1520 el modelo de La Celestina impresa en su mismo taller en 1514. Pero, teniendo en cuenta los precedentes iconográficos del suicidio de Enus, en manuscritos e impresos, es más lógico deducir lo contrario: que en la imagen del salto de Pleberio (La Celestina, 1514) tomara como modelo -o tuviera presente como uno de sus modelos- el de Enus. O tal vez el suicidio del propio Esopo, empujado por los ciudadanos de Delfos al final de su vida, que se reproducirá reducidísimo en uno de los dibujillos de los grabados que rodeaban el retrato de Esopo en las portadas o contraportadas de sus Vidas o de los Isopetes (Figs. 37 y 38). ${ }^{59}$

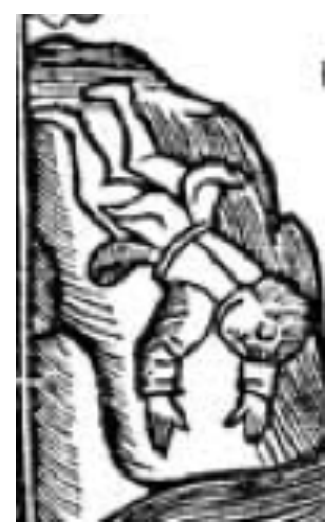

Fig. 37. Esopo despeñado en Delfos. Detalle (esquina inferior izquierda) de la Fig. 38

59.- Los detalles de esas miniaturas en su seudobiografía son analizados pormenorizadamente por Alvar, Carta y Finci (2011: 258). 


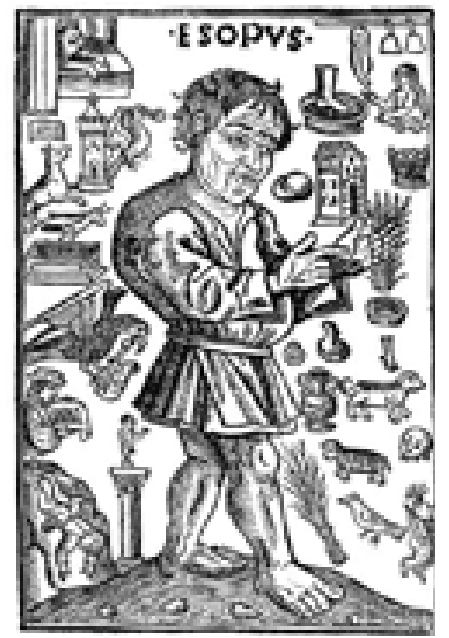

Fig. 38. Retrato de Esopo en la contraportada de La vida de Ysopo (Valencia, Juan Jofré, 1520)

Existe otro personaje del Antiguo Testamento que ha sido puesto en relación por Moreno (2007) con el suicidio de Melibea y que aparece en algunas miniaturas para iluminar letras capitales (Figs. 39 y 40). Se trataría de Ocozías, un rey de Judá del tiempo del profeta Elías (II Reyes, 1-2). Ocozías, castigado por Dios, cae desde una ventana, se lesiona gravemente y queda enfermo, encamado; parece que arrepentido, resolverá enviar una nueva embajada a los profetas. Ahora bien, aunque «esta sucinta descripción bíblica se convierte en una potente representación plástica», reconoce Moreno que Ocozías no es un suicida, sino un simple "caído». Se distingue claramente en las iluminaciones que se trata de una caída de espaldas accidental, no de un verdadero salto realizado ex profeso.

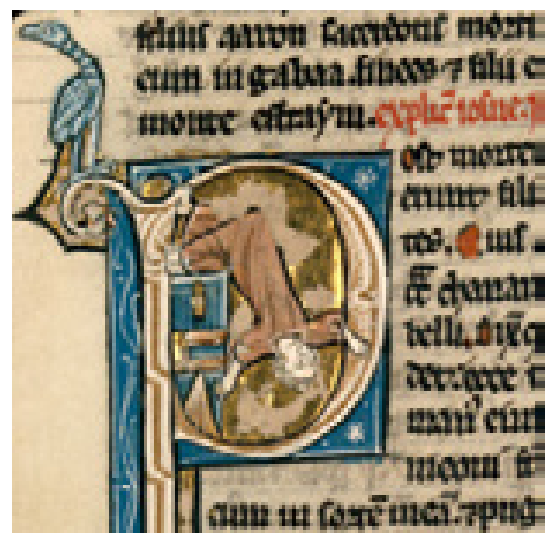

Fig. 39. Apud Moreno (2007) 


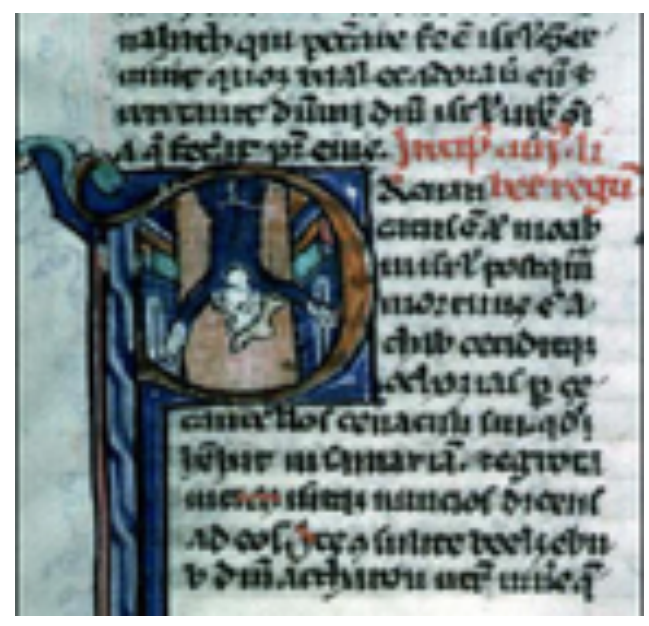

Fig. 40. Apud Moreno (2007)

Finalmente, solo encuentro una imagen que haga coincidir el suicidio desde una torre con el suicidio en la horca, como el de Judas. Dos suicidios, además, protagonizados por sendas mujeres, una de ellas ya bien conocida. Se trataría de la imagen que presenta la muerte de Dido y de Filis, en el ms. del Roman de la Rose (Rouen, ca. 1525), M.948 de la Morgan Library de Nueva York, fol. 129v. Filis, hija del rey Licurgo de Tracia, se enamora y tiene una relación con Demofonte, hijo de Teseo y Fedra, a quien acoge en el palacio de su padre cuando éste llega náufrago a las playas del reino. Pero Demofonte ha de partir para su patria Atenas y lo hace prometiendo volver. Ante el incumplimiento de su promesa, Filis, en una de las dos versiones del mito, que recrea Ovidio en sus Heroidas, se ahorca. Es el final que recoge la insólita y magnífica ilustración, con Dido suicidándose en la torre y, a la derecha, Filis ahorcándose de un árbol. ${ }^{60}$

Son imágenes de caídas, saltos, suicidios..., casi todos - observemosfemeninos. Ninguna, curiosamente, tan cercana a la muerte por salto de Pármeno como la de Enus, el traidor a su tío Esopo. Pármeno se «lee» como traidor suicida por los impresores. Y por eso su muerte es reproducida con el modelo del dibujo de la de otro traidor suicida, con quien algunos impresores estaban bien familiarizados: Enus. 


\section{Imágenes de codicia, traición y muerte: pecunia viscera sunt avari}

\subsection{La bolsa de Celestina y las treinta monedas}

Antes de insistir en las imágenes de la muerte de los codiciosos, hay que pasar por las imágenes de la codicia en sí. Fernández Rivera (2013) ha sido el primer estudioso que, a propósito de la bolsa de dinero que aparece colgada al cinto de Celestina en la mayoría de los grabados de Burgos (1499), donde aparece retratada, ha destacado la decisiva influencia de la iconografía de Judas en la de La Celestina (Fig. 41). El autor destaca la influencia de este personaje, que descuella entre la iconografía religiosa de la obra, y en particular entre la relacionada con la traición y muerte de Jesús. ${ }^{61}$

Fernández Rivera (2013: 189-191) presenta tres casos, entre los grabados de algunas ediciones tempranas de La Celestina, en los que destacan especialmente las trazas de episodios principales de la iconografía cristiana. En primer lugar, la Visitatio de María a su prima Isabel sería modelo de dos ilustraciones de la Comedia de Burgos (1499); en segundo lugar, las imágenes de Judas portador de una bolsa, a modo de faltriquera, que se transforman en la representación de la vieja alcahueta portando una bolsa semejante, en siete de los ocho grabados en que aparece en esta misma edición; y, por último, toda una serie de elementos asociados con las negaciones de San Pedro, que pasarían a la xilografía de la ejecución de los dos criados en las ediciones sevillanas.

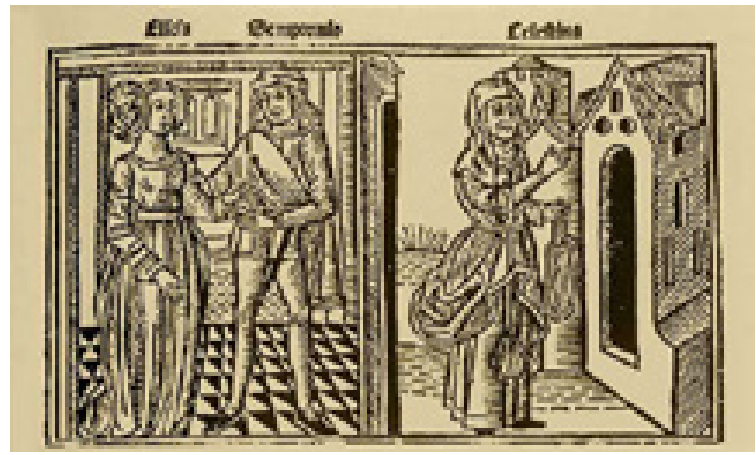

Fig. 41. Celestina con su bolsa de monedas (Burgos, 1499)

61.- Como dice Fernández Rivera: «En los grabados de las primeras Celestinas ilustradas, los compradores intuían, e incluso reconocían, la procedencia religiosa de los diseños y sus técnicas de representación. Estas semejanzas les animaban a comprar un libro cuyos grabados prometían una historia interesante que contenía, además, una útil ejemplaridad» (2013: 192). El estudio de la iconografía de las primeras ediciones de La Celestina cuenta con numerosas aportaciones - sin contar con los trabajos de Fernández Rivera, que nos interesan especialmente y hemos ido citando-, desde la pionera en el tema de Snow (1987; también 2005) hasta las más recientes de Iglesias (2016), pasando por otras muchas. Véase, a modo de balances posteriores, Lacarra (2020) y Saguar (2015, 2017a, 2017b). 
Es común en las primeras xilografías de La Celestina la presencia de una bolsa, se presupone que de dinero, que la hechicera lleva colgada de su cintura. Aunque apenas aparece mencionada en el texto, es ostensible en los grabados de la edición de Burgos (1499) como elemento identificativo y simbólico. En todos menos uno de los ocho grabados de esta edición, aparece Celestina llevando la bolsa de dinero, a pesar de que este complemento no tiene relación con la acción descrita en las imágenes (salvo en el grabado del auto II, que se podría relacionar con la donación del auto I). De ser monedero, naturalmente la bolsa guardaría las cien monedas mencionadas al final del acto I, como adelanto al pago a sus servicios. Lo cierto es que la «bolsa» - me planteo- sólo se menciona una vez en la obra y como genérico: «buena bolsa para necesidad, arca para guardar dinero en prosperidad» (VII, 164), mientras que, eso sí, la "faltriquera», que es lo que propiamente lleva la Celestina de los grabados, se menciona, si bien tampoco como monedero: «Aquí llevo un poco de hilado en esta mi faltriquera con otros aparejos que conmigo siempre traigo...» (I, 104). Es cierto, con todo, que los dineros podrían haber ido holgadamente depositados entre ese "aparejos», que son productos de farmacia.

En las imágenes de la Celestina, según detecta Fernández Rivera, la bolsa no desempeña una función real ni se refiere a ningún pasaje del texto en concreto, sino que refleja una conexión con la representación icónica de Judas y sugiere un nexo visual entre la alcahueta y el traidor bíblico. No hace falta la bolsa para reconocer a Celestina y distinguirla de otros personajes $y$, sin embargo, la bolsa actúa como un indicio icónico -un "atributo o emblema», señala Fernández Rivera-, como si se tratara de un signo puente entre la codicia de la portadora y la codicia de los cómplices del engaño o traición. El atributo de Judas, que lo identifica figurativamente como codicioso entre los otros discípulos, es la bolsa de las treinta monedas. Como señala Fernández Rivera:

Aunque la presencia de la bolsa es pertinente a la acción sólo en las representaciones de la venta o traición de Cristo ante los sacerdotes, tradicionalmente se la incluye en la cintura, el cuello o la mano de Judas en otras escenas como última cena, el prendimiento de Cristo o la muerte de Judas. En estas escenas, la bolsa no juega un papel en la acción sino que funciona como atributo para identificar a Judas y caracterizarlo como traidor codicioso. (2013: 187)

Y poco más adelante:

Ningún otro personaje [de la obra] lleva un atributo que lo identifique en sus diferentes apariciones en los grabados. La razón [...] pudo haber sido una intuición de que 
es el personaje más importante de la obra [...] $\circ[\ldots]$ su deseo de enfatizar la ejemplaridad moral de una obra en que se castiga la avaricia y la traición... (2013: 189)

Siguiendo a Fernández Rivera, por tanto:

El principal motivo que llevó al ilustrador a elegir la bolsa como atributo de Celestina es evidentemente el parecido entre los personajes de Celestina y Judas. Al igual que Judas vende a Jesús, Celestina vende a jóvenes muchachas, incluida Melibea. Al igual que Judas se apropia del dinero que los apóstoles le confiaron para que lo administrara, Celestina quiere quedarse con el dinero de sus socios Pármeno y Sempronio, por lo que éstos la matan de «más de treinta estocadas», un claro eco de las treinta monedas que al final llevan a Judas al suicidio. (2013: 189) ${ }^{62}$

\subsection{Codicia y traición de Eneas en Castigos del rey Sancho}

Codicia y suicidio no están vinculados en otro personaje histórico relevante que no sea Judas. Hemos visto que los motivos del suicidio o de la desperatio eran varios, pero no la codicia. Codicia y traición sumados, en cambio, sí que pudieron provocar el suicidio de otro actor literario. Es el caso de Eneas (causante del suicidio de Dido), tal y como se presenta en alguna versión medieval, como vamos a examinar.

A propósito de esta bolsa y de otros receptáculos de monedas, creo que no ha sido apuntado hasta ahora que la secuencia que media entre las monedas de la traición y el suicidio de Judas podría haber tenido otro antecedente importante, precisamente en las ilustraciones a la versión de la leyenda de Eneas y Dido que ofrece el ms. 3995 de la BNE de Castigos del rey Sancho, alguna de ellas aducida, eso sí, como imagen precursora del suicidio de Melibea (Moreno, 2007). El capítulo XL de Castigos está dedicado a la traición y dos imágenes describen la apertura y cierre de esta conocida historia, con una pauta que Bizzarri (2002: 67-68) detectó que se repite en otros relatos intercalados en la obra. ${ }^{63}$ Presentada como relato

62.- Fernández añade: "La razón que hizo al grabador dar este tratamiento exclusivamente a Celestina puede haber sido una intuición de que es el personaje más importante de la obra [...] $\bigcirc$ puede deberse también a su deseo de enfatizar la ejemplaridad moral de una obra en que se castiga la avaricia y la traición...» (2013: 189). Se podría añadir tan sólo, si acaso, que el avaro recuerda a Judas el Tarot más antiguo, del siglo Xv, en una carta que se presta aún a la interpretación: un Judas colgado hacia abajo, que ni en esta difícil posición suelta las dos bolsas de dinero, una en cada mano (Fig. 34).

63.- Véase para el programa iconográfico de este manuscrito, Haro (2012 y 2014). Agradezco a Marta Haro sus comentarios a este capítulo del artículo. 
ejemplarizante de los alcances de la «traición» (económica y política), en Castigos, sin embargo, no se pone el énfasis en la pasión sentimental y el desengaño amoroso, sino en la codicia de Eneas, que es la que motiva una doble traición y resulta causante última del desenlace fatídico de Dido. Porque Eneas no traiciona por despecho, sino primero por pura codicia y, luego, en una segunda traición, por vergüenza o cobardía, cuando huye de Cartago. El capítulo XL se centra en "De cómmo se non deue omne pagar del omne traydor». Se define traición y se diferencia de falsedad y alevosía; se aducen ejemplos varios de traiciones, entre otros pocos la traición a Alejandro Magno, la de Ganelón y, cómo no, la de Judas, sin ofrecer mayores detalles en ninguno de estos tres casos. Pero en el capítulo la parte expositiva o doctrinal sobre el pecado se contrapesa con la narrativa y ejemplarizante. Y ésta se concentra y limita al ejemplo de Dido y Eneas:

E por que entiendas que te digo verdat, para mjentes en la estoria de Troya, e fallarás ý cómmo se perdió Troya por la trayçión que fizo Eneas. E desque la çibdat fue perdida, e el rey Príamos fue muerto, e la noble reyna Écuba, su muger, $e$ todos sus fijos $e$ fijas, fuese el traydor de Eneas con el auer que le dieron los griegos por el mal que él fiziera. E metiose en vna naue sobre mar $e$ arribó a Cartago Dido. (Bizzarri, 2001: 284-285)

Troya se perdió «por la trayçión que fizo Eneas». El traidor Eneas huye y encuentra refugio en Cartago, donde casa con Dido y mora varios años. Un día, encuentra dibujada en las puertas del templo la historia de su traición, teme la difusión del hecho y, antes de que ocurra, escapa mintiendo a Dido. Ésta se sube a "una torre muy alta» y entre sus almenas razona con su pueblo:

diziéndoles muchas cosas en que pudiesen beuir, e de la su suerte ventura por ella ser casada con tal omne que así la auía burlado. E tomó vn espada, e metiósela por los pechos, e dexose caer, e dio tal ferida en tierra que luego fue muerta. E así acabó la reyna Dido su vida por el despecho que ouo de las trayçiones que fazia Eneas. (Bizzarri, 2001: 286) ${ }^{64}$

Pues bien, principio y fin de este relato están jalonados, en el citado manuscrito, con sendas ilustraciones. La segunda, la que cierra el relato, es la que hemos visto de Dido arrojándose desde la «torre muy alta»

64.- Hay ciertas discrepancias en las lecturas que hacen del pasaje las distintas ramas de mss. de Castigos, e incluso en las lecturas de una misma familia (véase n. 65). Pero no se discrepa en torno a la doble traición de Eneas. 
(Fig. 17). ${ }^{65}$ Pero «las trayçiones que fazia Eneas» habían sido dos. Y, así, la primera ilustración, la que abre la historia, no es menos insólita que la segunda (Fig. 42). La imagen muestra al parecer a Eneas siendo pagado con las monedas de la traición a los troyanos ("el auer que le dieron los griegos por el mal que el fiziera»), cuarenta monedas refulgentes que se aprecian perfectamente redondeadas y pintadas en dorado, mientras salen uniformes, vertidas de un saco que se diría cuerno de la abundancia. La imagen es tan luminosa y potente como anómala en el panorama ilustrado medieval.

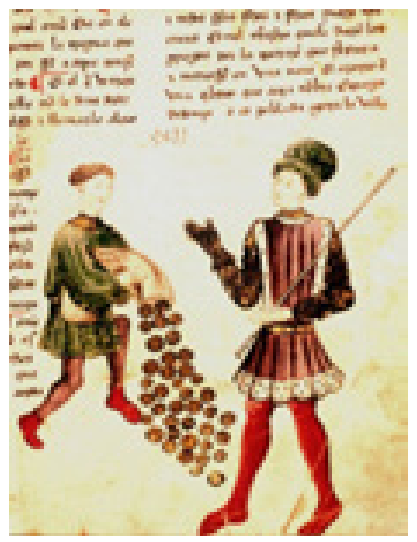

Fig. 42. Castigos del rey Sacho, BNE, ms. 3995, fol. 66

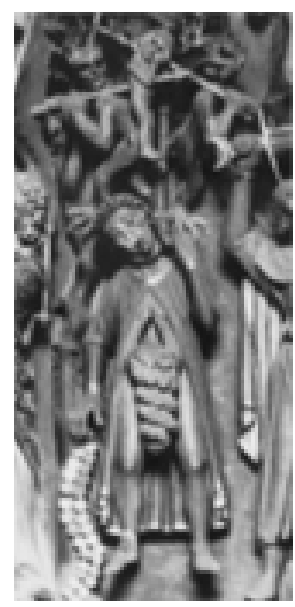

Fig. 43. Detalle del portal oeste

de la catedral de Friburgo de Brisgovia (c. 1300)

65.- Como reza el texto, aunque sin la espada a la que éste hace alusión y sí con la presencia del fuego, que el ms. base del que se sirve el editor para la edición crítica (ms. E) no menciona. Sin embargo, sí que aparece, con algún otro sabroso detalle añadido, en la lectura del otro ms. (ms. A) de la misma familia que el ms. E (Bizzarri, 2001: 284-286 y ns.) 
La propia Moreno (2007), que la analiza pormenorizadamente, reconoce no haber podido encontrar imágenes similares a esta que presenta el ms. C (BNE, ms. 3995) de Castigos del rey Sancho. ${ }^{66}$ Una imagen con tantas y tan visibles monedas solo la encuentro tan explícita en otra representación igualmente excepcional, si bien serán en este caso treinta, exactamente treinta, y no cuarenta las monedas derramadas. ${ }^{67}$ Pero esa imagen resulta que precisamente se halla, de nuevo, dentro de la convención del ahorcado eviscerado que representa la muerte de Judas suicida. Se trata de un bajorrelieve del tímpano de la puerta oeste en la catedral de la Friburgo alemana (de Breisgau o Brisgovia) (Fig. 43). ${ }^{68}$ Podemos observar cómo los círculos acumulados de las monedas caen como vertidos o evacuados (como caen volcados en la ilustración de Castigos) junto al cuerpo del traidor avaro, jugando en paralelo con las elipses aglutinadas de los intestinos que se desentrañan. Desde la lectura de Pedro Coméstor se admitía que los demonios — aquí los dos agazapados, en la parte superior, como aves carroñeras al acecho - no pueden extraer el alma de Judas por la boca para llevarla al Infierno, como era habitual en la representación de convalecientes exhalando el último aliento, porque esa boca había tenido contacto con Jesús. ${ }^{69} \mathrm{Y}$ es que el dinero se identifica con las vísceras del avaro, pecunia viscera sunt avari, como decía Bernardo de Claraval en sus comentarios al pecado de desesperación de Judas, y a propósito de su muerte, cuando citaba, en Hechos, que difusa sunt omnia viscera eius. ${ }^{70}$

66.- Moreno: «Las dos últimas corresponden al capítulo 40, destinado a hablar sobre el traidor y al cual se dedican dos iluminaciones que recrean la historia de Dido y Eneas. Una vez más las imágenes describirán una escena inicial y otra final del relato. En la primera (fol. 66r), se muestra a Eneas recibiendo el tesoro de los griegos en pago de su traición: "fuesse este eneas con el thesoro que le dieron los griegos por la traycion que fiziera", fol. 66r. En la segunda (fol. 66v), se muestra a Dido deshonrada lanzándose de lo alto de la torre. Como se puede ver, el hecho de dedicar dos imágenes para cada episodio no es un mero paralelismo en esta parte final de las secuencias iconográficas del códice. Se trata más bien de una técnica sintetizadora de la narración, ofreciendo el nudo y el desenlace del relato» (2007).

67.- Como dice Murray: «the suicide Judas now lacks nothing either from the New Testament- the intestines and the thirty pieces of silver (precisely thirty: the Freiburgers did not make mistakes about counting money) -or from popular lore, source of the devil who makes off with Judas' soul» (2000: 330-331).

68.- El cambio de la representación de Judas ahorcado (suicidado) de un árbol a Judas ahorcado (punido) de una horca preparada para el castigo ha sido analizado por Schnitzler (2000) para ayudar entender el proceso de inclusión del tema del suicidio como asunto legal.

69.- La mejor descripción e interpretación del impresionante relieve de Freiburg la encuentro en Coffey (2013: 78-79).

70.- Recuerda oportunamente la cita, en este contexto, Lafran (2007: 167). 


\section{Traición, caída y muerte de Pármeno}

\subsection{Traición y transformación de Pármeno}

Celestina es codiciosa y traiciona a los suyos, sí. Pero es asesinada violenta, vil e injustificadamente en el auto XII. Pármeno y Sempronio, al comprobar que la vieja no va a realizar el reparto pactado, estallan en un ataque brutal de ira, y cometen un homicidio que no tenían premeditado al acudir a reclamar sus partes del botín. Ellos, más que la vieja, son los verdaderamente codiciosos y traidores a su amo, y quienes serán castigados — ante la desperatio, sin otra salida - con un infamante autoinmolación, al arrojarse desde lo alto de manera suicida y morir.

Snow (2013) ha explicado con todo pormenor y agudeza los pasos dados desde la creación de una confraternidad de tres miembros (o "confederación", que es el término que Snow utiliza, tomado de La Celestina, vIII, 193). Esa unión se urde por puros intereses económicos, ya hacia el final del auto I, cuando Celestina recibe el anticipo de «cien monedas en oro" (I, 81) de parte de Calisto, una cantidad seguro que exagerada o imprecisa en el texto, por lo elevada.

Pármeno, decíamos, es de entre los tres quien realiza una metamorfosis más radical desde la lealtad hasta la traición. Su supuesta firmeza moral (o remilgos por falta de experiencia) se presenta al principio como un hueso difícil de roer para Celestina, a la hora de fraguar los detalles de la confabulación. Celestina ha de escuchar, en el auto I, desde fuera de casa de Calisto, cómo Pármeno critica su pasado y desnuda sus atributos, cómo describe con pormenores de entomólogo su laboratorio, y resume sus oficios, sacando a la luz sus fraudes e hipocresía (que todo, según él, era «burla y mentira»; auto I, 61-62). Y ha de escuchar, sobre todo, cómo da muestras de inquebrantable fidelidad, primero ante el propio Calisto (I, 63-64) y después, también por detrás, mostrando que este rendimiento de servicio es sincero (I, 69). Celestina no se arredra ante esos escollos, sino que sabe que ha de utilizar alguna estrategia: necesita ganarse la complicidad de Pármeno. La puerta se le abre cuando lo descubre como hijo de Claudina, amiga ("uña y carne», III, 100), y de Alberto, "compadre» de Celestina (I, 70) (Snow, 1986, 1989). La «caída» de Pármeno describirá, para Heusch (2000), que propone un novedoso giro interpretativo del personaje, los pasos en la trayectoria de un ángel caído, luciferino. Incluida su relación un tanto cainita con su «hermano» Sempronio. ${ }^{71}$ No era necesario, en efecto, que se explicitara de manera tan pormenorizada el linaje de Pármeno, si

71.- Heusch (2000: 38) propone una conexión entre el nombre bastante raro en la Castilla del xv, de raíz germánica, Alberto, y otro semejante, Roberto (Roberto el Diablo). Ambos connotan aspectos diabólicos, como demuestra el Alberto diablo mencionado en el Libro del caballero Zifar, lo que podría relacionarse con un regreso a los orígenes, en la plausible tesis que defiende Heusch de que la trayectoria de Pármeno sigue los pasos de la de un ángel caído. 
no se hacía para insinuar una suerte de relación de base edípica con Celestina (su otra madre, en sustitución de Claudina), semejante a la de tantas otras leyendas populares, incluida, como hemos visto, la de Judas. ${ }^{72}$

Cuando Celestina conoce esa filiación, le dice a Sempronio, con mucha mayor confianza: «yo te le haré uno de nos, y de lo que hobiéremos, démosle parte, que los bienes, si no son comunicados, no son bienes. Ganemos todos, partamos todos, holguemos todos» (I, 65)..$^{73}$ Sempronio no es un problema; Pármeno, sî. ${ }^{74}$ La fidelidad de Pármeno parecía confirmada. Sin embargo, cambia definitivamente de actitud en los autos VII y VIII (aunque hay atisbos previos). El principio del cambio se produce cuando le confiesa a la alcahueta que está de su parte o que al menos ya no será una interferencia para ella: «Haz de las tuyas, que yo callaré. Que ya tropecé en no te creer cerca deste negocio con él [Calisto]» (VII, 167). Luego, ya en casa de Areúsa, Celestina se aprovecha de que espera poseer a Areúsa y le obliga a prometer fidelidad antes de entregarle su premio (VII, 169-173).

Pármeno es consciente de su traición, al incumplir el pacto de lealtad: « $\mathrm{O}$ traidor de mí, en qué gran falta he caído con mi amo!» (VIII, 187). Aunque Sempronio replica a sus reticencias con el argumento de que Calisto, enajenado, no le corresponde como buen señor: «no se acuerda de sí; ¿acordarse ha de ti??» (VIII, 194). En el auto IX la complicidad aumenta, cuando roban de casa de Calisto comida y bebida para disfrutar en casa de Celestina, con ella y las dos primas.

Calisto ya le había prometido a Celestina un manto y una saya (VI, 153). Pero cuando recibe la noticia de la cita para el encuentro secreto, confirma y aumenta con creces el valor de esa promesa: «Madre mía, yo sé cierto que jamás igualarán tu trabajo y mi liviano galardón. En lugar de manto

72.- Stamm (1977) ya deducía que su doloroso pasado habría llevado a Pármeno a interiorizar demasiado sus emociones. También en esa línea de persona frágil, dubitativa ante tantas nuevas tentaciones, discurre el análisis de Treusdell (1975). Pero es Tozer (2003) quien va más lejos en las implicaciones de un posible trauma edípico infantil, al profundizar en esas relaciones que conducirían a la «emasculación» simbólica de Pármeno: «manifiesta signos perceptibles (externos) de masculinidad — capacidad sexual y violencia — [y] paradójicamente se transforma en la encarnación de la debilidad» (2003: 162).

73.- Como dice Snow: «Se trata de la idea de compartir los tres — ganando, repartiendo y holgando-, que conforman un irónico preludio a su propia tragedia. [....] Son pronunciadas estas palabras ante el lector con fina ironía justo en el preciso momento en que el 'servicio' de Sempronio anda por otro camino y con una finalidad desconocida por su amo» (2013: 124-125).

74.- Calisto, en el auto II, inconsciente de lo que se trama, se dirige al principio a Sempronio encareciendo su lealtad: «Sempronio, amigo, pues tanto sientes mi soledad, llama a Pármeno y quedará conmigo, y de aquí adelante sey como sueles leal. Que en el servicio del criado está el galardón del señor» (II, 87). Y Calisto mantiene esa inocente creencia en la lealtad de su criado mayor hasta mucho más adelante, cuando todo el engaño está urdido. El autor juega irónicamente con esa inocencia, cuando pone en boca del amo estas palabras, que resuenan como un eco repetido de las del auto II, confirmando la idea de la lealtad: «Sempronio, mi fiel criado, mi buen consejero, mi leal servidor, sea como a ti parece. Porque cierto tengo, según tu limpieza de servicio, quieres tanto mi vida como la tuya» (auto VIII, 198). 
y saya [...], toma esta cadenilla; ponla al cuello...» (XI, 233). Sempronio se enfurece y encona al saber esto. Y anticipa de algún modo la magnitud de la tragedia, diciéndole a Pármeno: "Pues, guárdese del diablo, que sobre el partir no le saquemos el alma!» (XI, 237). Pero Pármeno no se salva del encono. En el auto XII, se muestra la cobardía de los dos. En vez de defender la retirada de su amo, y mostrarse dispuesto a espantar a los escuderos de Pleberio, a Pármeno lo delatan los nervios, y muestra su miedo (XII, 242-243). Al sentir un ruido cercano, dice él: «iHuye, huye, que corres poco! j[...] dexa broquel y todo!» (XII, 249), para poder escabullirse lo más rápido posible. Y cuando, ya lejano, Sempronio le pregunta a su compañero: «¿Si han muerto ya a nuestro amo?», Pármeno responde: «No sé; no me digas nada. Corre y calla, que el menor cuidado mío es ése» (XII, 249).

Pármeno sufre una definitiva transformación hacia la cobardía y la hipocresía en el auto XII. Cuando está a punto de huir, y cuenta su postura grotesca a Sempronio (porque es de noche) (XII, 248) y cuando le habla a Celestina, como todo un bravucón, de «la alteración que traemos, que cierto te digo que no querría ya topar hombre que paz quisiese» (XII, 254) (porque se supone que querría pelearse con todos). Es Sempronio, con todo, quien toma siempre la delantera en las decisiones, cuando van a la casa de la hechicera a reclamar sus dos terceras partes del botín: "Danos las dos partes por cuenta de cuanto de Calisto has recebido» (XII, 258). Además, es él quien le pregunta con una voz amenazante: "¿No serás contenta con la tercia parte de lo ganado?» (XII, 260). Y sigue siendo Sempronio el más violento de los dos al oír a Celestina llamarles "rufianes», expresión que le lleva a un punto de no retorno: «¿Rufianes o qué? Espera, doña hechizera, que yo te haré ir al infierno con cartas» (XII, 260). Y es cuando probablemente pierde el control y acaba con ella, animado por el cobarde Pármeno: «Dale, dale, acábala, pues començaste, que nos sentirán. ¡Muera, muera! ¡De los enemigos, los menos!» (XII, 261). Creo que este grabado de Valencia, Juan Viñao, 1529 (Fig. 44), es una excepción a la regla, pues refleja la muerte de Celestina por los dos criados con toda su crudeza, pero en un dibujo exento, cuando en la mayoría de grabados siempre aparecen los criados con Elicia, o en combinación todos con la acción posterior del salto por la ventana. ${ }^{75}$

75.- Juan Viñao e ilustrador anónimo, «Ilustración segunda del acto XII de la edición de Valencia (1529)», CelestinaVisual.org, consulta 25 de septiembre de 2020: <http://celestinavisual.org/items/show/668>. 


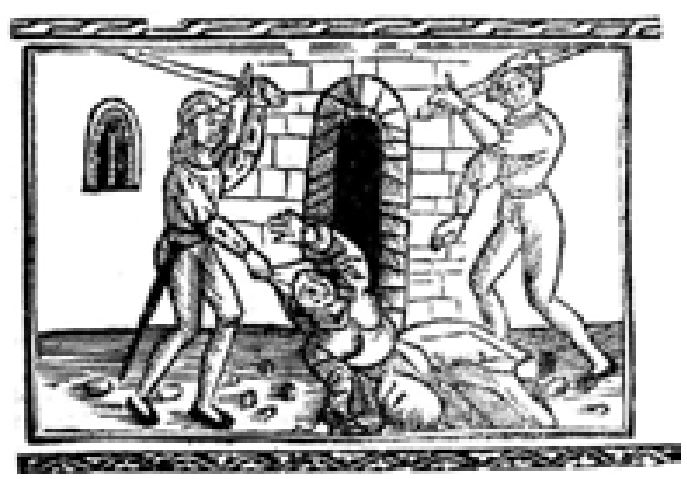

Fig. 44. La Celestina (Valencia, 1529)

La cobardía de Pármeno es manifiesta. ${ }^{76}$ Ha sido Sempronio quien siempre ha llevado, hasta el final, la iniciativa. Pero es por eso por lo que su deriva hacia el descontrol colérico resulta de algún modo no justificada, pero sí coherente. Mientras que la trasformación inesperada del mucho más pusilánime Pármeno, el otrora fiel criado, es en cambio mucho más sorprendente, y totalmente injustificada su cobarde acción.

\subsection{La caída de Pármeno y la muerte ajusticiado}

La caracterización de Pármeno está condicionada por su final dramático. Como la de Judas. Ambos criados describen y avanzan por vectores en paralelo - en trazos rectos o sinuosos- desde la lealtad hasta la traición causada por codicia; una línea que desemboca en la muerte atroz. En Sempronio, insistamos, la fidelidad había estado siempre en entredicho. Es Pármeno quien experimenta una transformación vertiginosa, quien se muestra más débil y expuesto ante la codicia (cupiditas sexual primero y económica luego). Teniendo la posibilidad de rebelarse al pecado, es tentado y sucumbe. Como dice Lafran, a propósito de Judas: "La mort de Judas, c'est le châtiment du traître, de l'usurier, de l'impie, du pécheur: c'est l'image même de la damnation" (2007: 175). La condena moral de Pármeno estaba también seguramente prevista, teniendo en cuenta su pecado de codicia y traición; pero el asesinato de Celestina no hace más que acelerarla y precipitar el castigo — casi como una autopunición — con su muerte, que no resulta accidente fortuito, sino justicia providencial.

Si yuxtaponemos la versión de la muerte de Judas en Hechos y la versión de la muerte de los criados en La Celestina, se diría que la una com-

76.- Tozer la interpreta como una especie de temor, como el típico de los adolescentes en su grupo, a ser "emasculado», excluido: "Su remate final de supuesta valentía está arraigada en una especie de debilidad emocional: la cobardía. Ésta se presenta como un temor a la exclusión del mundo de los hombres, el cual queda hecho pedazos al final de la obra» (2003: 162). 
pleta vacíos de la otra, haciendo que en cierto modo se complementen. Mientras que Hechos habla de caída "de cabeza», el texto de Rojas no menciona ese "de cabeza", pero se ha de presuponer necesariamente, como hemos ido viendo y como entendieron los primeros lectores. Los grabados interpretaron "salto de cabeza» (como el de Judas y como el de las caídas ilustradas de suicidas que hemos ido desgranando), aunque la Tragicomedia habla solamente de "salto" y luego, eso sí, de "sesos de la cabeça de fuera» (Figs. 1, 2 12, 45 y 46). ${ }^{77}$

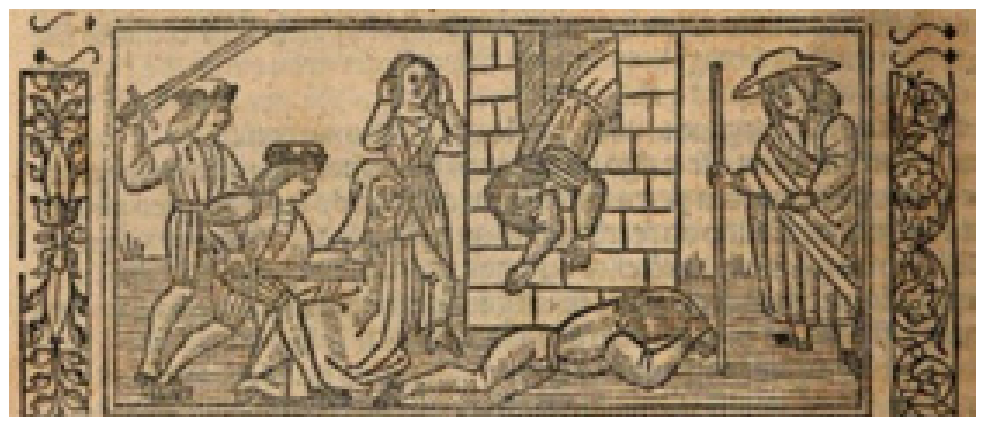

Fig. 45. Asesinato de Celestina y salto de Pármeno (Burgos, 1531)

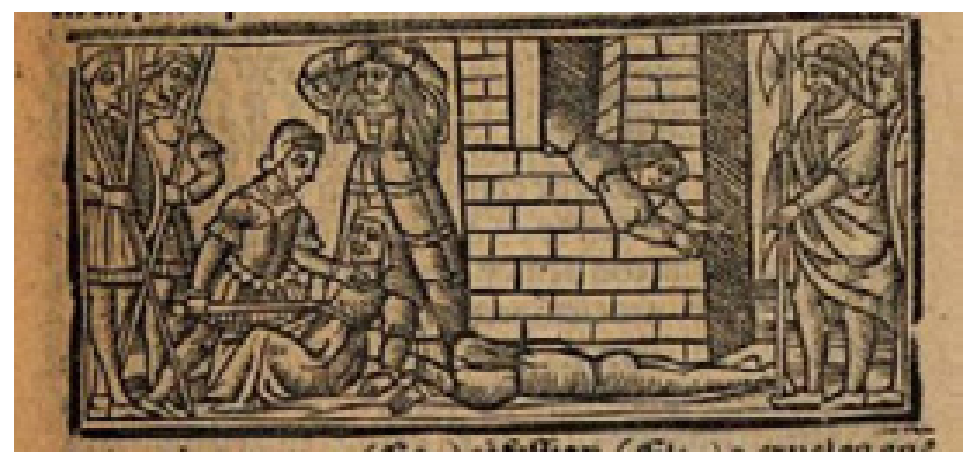

Fig. 46. Asesinato de Celestina y salto de Pármeno

(Sevilla, 1523; Venecia, 1534)

Hechos tendría que haber dicho lo mismo, por pura lógica, y no que al caer Judas, contra toda razón, "reventó por medio y se esparcieron todas sus entrañas». Lo cierto es que probablemente, como hemos visto

77.- Fig. 45: Juan Viñao e ilustrador anónimo, «Imagen segunda del acto XII de la edición de Burgos (1531)", CelestinaVisual.org, consulta 25 de septiembre de 2020: <http://celestinavisual.org/items/show/1434>. Fig. 46: Stefano da Sabio e ilustrador anónimo, "Grabado segundo del acto XII de la edición de Venecia (1534)», CelestinaVisual.org, consulta 25 de septiembre de 2020: <http://celestinavisual.org/items/show/511>. Ejemplar en la Biblioteca de Catalunya: <https://books.google.es/books?vid=BNC:1000084132\&printsec=frontcover\&re dir_esc $=\mathrm{y} \# \mathrm{v}=$ onepage $\& \mathrm{q} \& \mathrm{f}=$ false $>$. 
en la iconografía de su muerte, la imagen del ahorcamiento se fundió con la de esas vísceras, provocando una solución sincrética - la del ahorcado eviscerado-, con una fuerza visual poderosísima, que fue finalmente adoptada y triunfó. No sólo eso, sino que la imagen de los sesos esparcidos por suelos y paredes aparecerá en otra caída mortal, la de Calisto ("Coge, Sosia, esos sesos de esos cantos»), como igualmente comentaremos más adelante.

Por tanto, si nos apoyamos en la acción de Judas en Hechos, se comprende mejor que a uno de los dos criados se le abra la crisma - "llevaba todos los sesos de la cabeza de fuera, sin ningún sentido»—y que el otro quede con traumas y contusiones: «quebrados entramos brazos y la cara magullada». Y los dos: «todos llenos de sangre» (Sosia). Las contradicciones, en todo caso, van a continuar, porque recogen sus cuerpos vivos pero inmediatamente los decapitan, sin mediar espera, prisión ni juicio alguno. Los cuerpos muertos de La Celestina — antes mutilados, rotos, despedazados- se hacen así simbólicos, como han destacado Sanmartín (2005) y Mier (2016), se convierten ellos mismos en un espacio donde se lacera y castiga el asesinato, la locura de amor o la alcahuetería. Rojas no tiene compasión con esos pecadores, sino que moraliza seccionado despiadadamente sus cuerpos, vetándoles cualquier posibilidad de «buen morir».

La decapitación se muestra crudamente en algunos grabados, simultaneada con la escena de la caída. En alguna ocasión, exenta, como en el grabado de Sevilla, 1523 (Fig. 47). O en alguna otra, más ceremonial y naturalista, con la ejecución sobre una losa sacrificial, como en el grabado de la edición de Augsburgo, 1520 (Fig. 48).

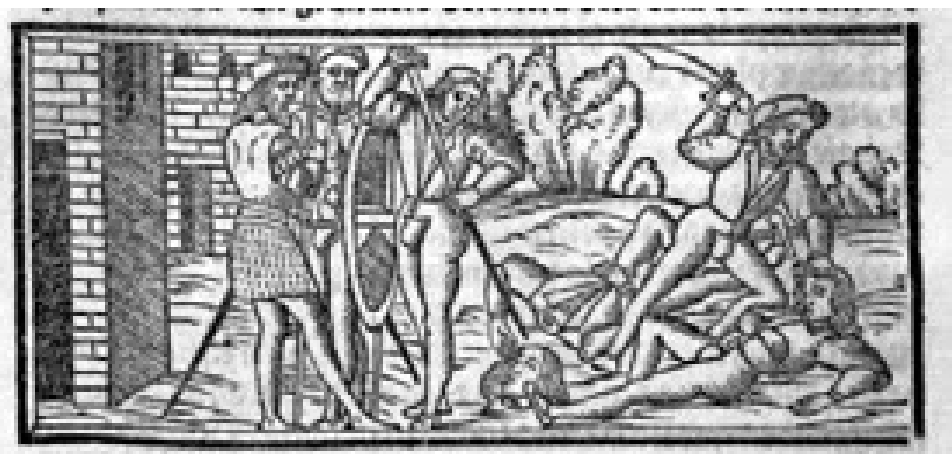

Fig. 47. Ajusticiamiento de Sempronio y Pármeno (Sevilla, 1523) 


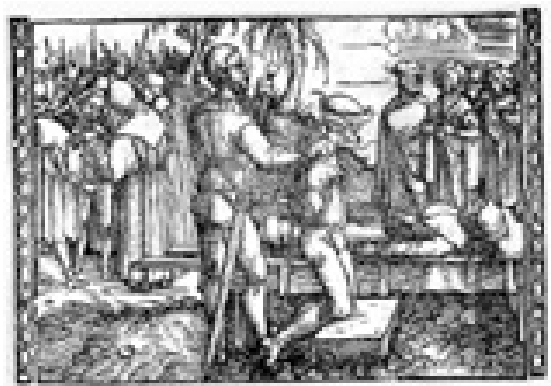

Fig. 48: Ajusticiamiento de Sempronio y Pármeno (Augsburgo, 1520)

El ajusticiamiento más lógico para este tipo de crimen habría sido el del ahorcamiento, pero quizás los cuerpos tan gravemente heridos no hubiesen podido esperar a los preparativos. Y, puesto que no había duda de la culpa (el salto mismo, desesperado o suicida, era prueba palmaria de ella), y había que dar una imagen pública aleccionadora, la degollación era una solución rápida y expedita. Si no era la más estrictamente legal, sí resultaba bastante verosímil y sobre todo útil para hacer avanzar la acción en la Tragicomedia: "quedan degollados en la plaza» (dice Sosia, en auto XIII, 265) o "quedan descabezados en la plaza como públicos malhechores, con pregones que manifiestan su delito" (el mismo Sosia, en auto XIII, 266).

En todo caso, ese remate final, tan sumario y contra derecho, tan injusto y despiadado, dista mucho de lo que será el recogimiento misericordioso del cadáver de Calisto por parte de Tristán. ${ }^{78}$ Porque, pese a que Calisto ha muerto igualmente abriéndose la cabeza de la caída (Fig. 49), recibe un retiro y un recogimiento mucho más discretos y honrados:

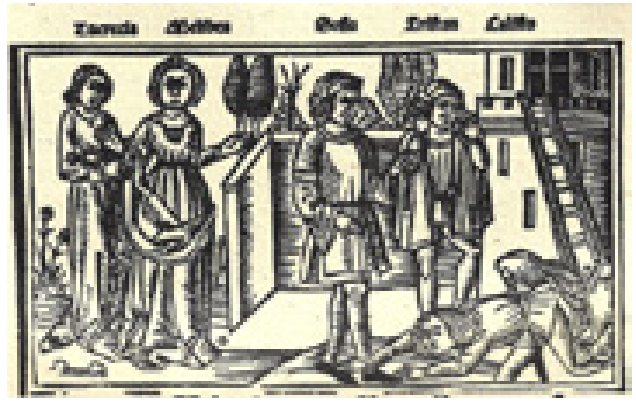

Fig. 49. Caída de Calisto (Burgos, 1499)

78.- Tan cruel como el maltrato a los animales. De hecho, son comparados con dos toros heridos en la plaza. Tristán, cuando llega y escucha la algarabía, no sabe si se trata de «alguna justicia» o de que «madrugaron a correr toros». La humillación de ser descabezados en la plaza como públicos malhechores, recuerda la de Leonor López de Córdoba y los suyos, al tener que ver cómo, tras morir, desherraban a sus familiares en el patio de las atarazanas de Sevilla (que hacían de cárcel), a vista de todos, "como a moros», sin la menor compasión. 
Al fin y al cabo, si en la Comedia moría sin mediar palabra, sin confesión, en la Tragicomedia sí que se le concede al menos que pida la confesión in extremis, pese a que Tristán insiste en que muere sin confesión:

¡Oh mi señor y mi bien muerto, oh mi señor despeñado! $¡$ ¡h triste muerte sin confesión! Coge, Sosia, esos sesos de esos cantos; júntalos con la cabeça del desdichado amo nuestro. [...] Toma tú, Sosia, desos pies, llevemos el cuerpo de nuestro querido amo donde no padezca su honra detrimento. (XIX, 324-325) ${ }^{79}$

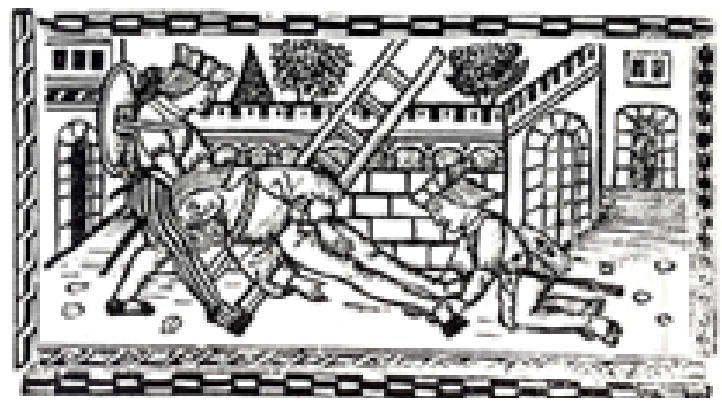

Fig. 50. Recogida del cuerpo de Calisto. La Celestina (Valencia, 1514)

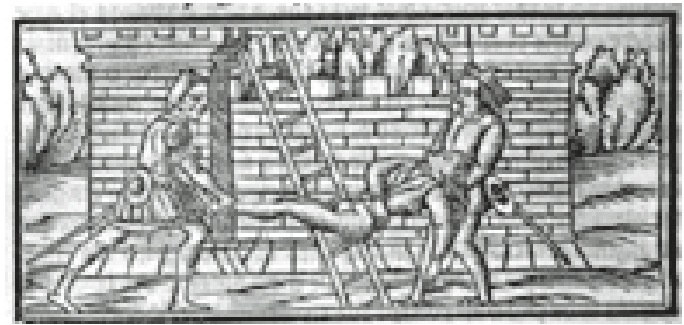

Fig. 51. La Celestina (Sevilla, 1523)

La imagen del cuerpo de Calisto recogido por sus criados ha sido comparada con las de la depositio Christi, con el descendimiento de Cristo, sobre todo partir de los grabados de las primeras ediciones, que son también testimonio de las primeras lecturas e interpretaciones de la obra (Figs. 50 y 51). ${ }^{80}$ No sería incongruente, entonces, en la misma línea interpretativa,

79.- Para los personajes de Sosia y Tristán, y la interpretación de la ambigüedad de sus intervenciones, véase Tozer (2004).

80.- Fernández Rivera (2011) analiza el grabado de la caída de Calisto en el ejemplar de la $C C M$ de Burgos, y muestra la influencia que éste ha tenido en las ediciones ilustradas de la obra de la primera mitad del siglo XVI. Probablemente los autores de la xilografía siguieron como modelo, voluntaria o involuntariamente, la representación iconográfica de la caída de Fortuna y la depositio Christi. 
comparar algunos de los restantes movimientos escénicos —en concreto, en estos episodios de muertes trágicas- con otros de la Pasión de Jesús. Y, entre ellos, como hemos ido viendo, uno de los más notorios era el de la traición de Judas, incluido su ahorcamiento. La imagen de su ahorcamiento, sin contar la caída, en la que nos hemos extendido suficientemente, pudo estar detrás no solamente de la llamativa e insólita portada de la edición de la Tercera Celestina de Gaspar Gómez de Toledo (Toledo, Hernando de Santa Catalina, 1539) (Fig. 52), ${ }^{81}$ sino también de algún grabado tardío, cuando se había olvidado el degollamiento de los criados de Calisto o resultaba más fácil sustituirlo por el castigo de la horca (Fig. 53). ${ }^{82}$
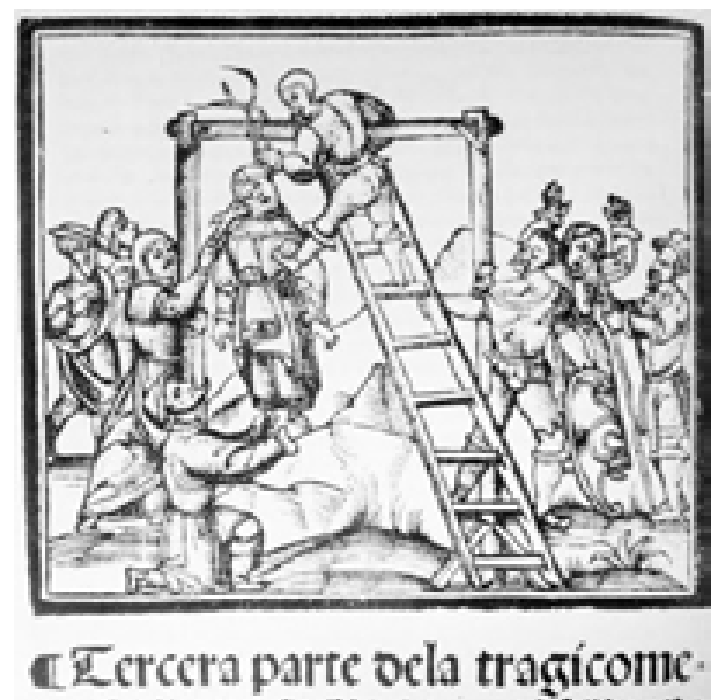

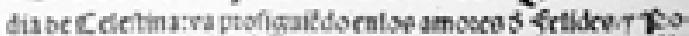

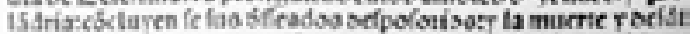

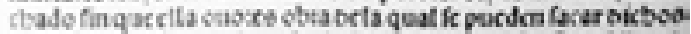

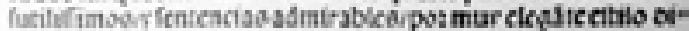

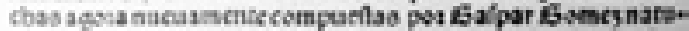

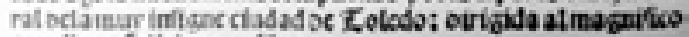
causllero felícians beflus.

Fig. 52. Portada de la Tercera Celestina (Toledo, 1539)

81.- Sobre esta portada llamó la atención, analizando la función y sentido del grabado, Bergman (2012: 63-65). Vuelve a reparar en sus peculiaridades, en otro contexto, Civil (2017).

82.- Como dice Fernández Rivera, en la Celestina Visual, se trata de una de las pocas imágenes en esta edición que no está copiada de la edición de Zaragoza (1545). Y añade esta importante nota: "Es posible que proceda de una imagen de un libro sobre la matanza de indios perpetrada por los españoles en las Américas que se publicaron en esos años. El estar la víctima desnuda y el haber un arco y flechas en el suelo parece indicar que se trata de un indio, aunque también puede ser una figura simbólica de Cupido al tener los ojos vendados y los atributos antes citados». 


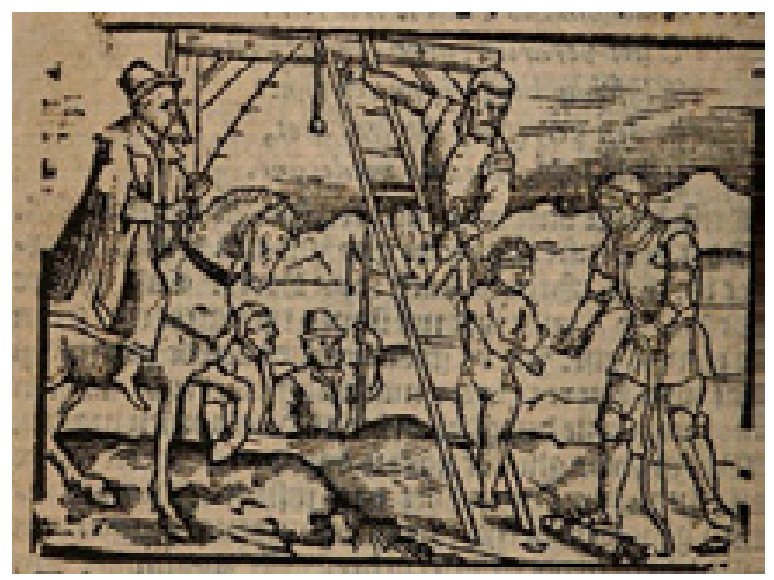

Fig. 53. Ejecucion de Sempronio y Pármeno (Amberes, 1616)

Aquí, la imagen de conjunto del descensus está radical e insólitamente invertida - con un grupo colaborando y el otro lamentando estentóreamente la tragedia - para reflejar el ascensus y muerte de uno de los criados de Calisto, Sempronio o Pármeno, con una horca de tres palos, y un ahorcamiento que de nuevo recuerda - entre otros ajusticiados o desesperados-las imágenes del Judas que se cuelga de un árbol o de una horca.

\section{Conclusiones}

Los condenados por los peores crímenes pagan sus delitos con las más estrepitosas caídas, como hicieron en la historia del cristianismo los ángeles precipitados desde los cielos o harán los pecadores en las visiones apocalípticas del Juicio Final. Hay notables precedentes, señalados por la crítica, para esas caídas accidentales por amor o por ambición (Calisto y sus criados), o por desperatio o suicidio (Melibea), que hallamos en la literatura bíblica o clásica, masculinos o femeninos (Ícaro, Faetón; Lucrecia, Dido, Hero). Sin embargo, algunos de los elementos oscuros que plantean las extremadas e ilógicas caídas y muertes en La Celestina se iluminan con más claridad cuando se leen teniendo presente la de Judas Iscariote, tal como la testimonian los escasos versículos que la presentan escueta pero dramáticamente en el Nuevo Testamento. Y sobre todo se iluminan cuando comprobamos la fuerza poderosísima de trasmisión de su leyenda, que se edifica y consolida sobre los cimientos de prácticamente sólo dos episodios especialmente significativos de participación en la Pasión: el del beso traidor a Jesús (incluyendo la Última Cena) y el de la muerte (Judas suicidándose, ahorcado). 
El primero lo hemos encontrado en todo tipo de testimonios iconográficos (tablas, cuadros, esculturas, pasos); y el segundo en numerosísimas representaciones populares, litúrgicas o paganas (o en sincretismo de ambas) que han mantenido su fuerza ritual desde la Edad Media hasta hoy. Si el motivo del beso traidor o el de la Última Cena no dejan vestigios claros en La Celestina (sería arriesgo plantear una relación con la comida del auto IX, aunque no sería en absoluto plantearla para algunos de los grabados de este auto), el episodio de la muerte de Judas sí que parece evidente que extiende y alarga su sombra sobre las muertes de varios de los personajes de la Comedia y la Tragicomedia. Como resume perfectamente Álvarez:

La muerte sin fe abría la puerta en la Edad Media cristiana a un solapamiento visual con la omnipresente iconografía de la desperatio: la muerte de Judas. Combinando también la espada para sacarse las tripas y el colgamiento para ahorcarse, Judas ahondaba en lo femenino, criminal y pecaminoso, pasando la desesperación de estado psicológico a vicio y crimen contra Dios. Esta asociación implícita, con igual ejecutor (la gravedad) y reconocible al receptor medieval, era el perfecto antídoto contra cualquier sentimiento heroico, simpatético o de admiración trágica hacia Dido. Igualmente, convertía su muerte en un castigo y su vida en un ejemplo a no seguir. (2017: 323-324)

La caída de Judas aúna como pocas otras el camino que va del vicio al mayor crimen (el crimen contra Dios). Judas encarna como nadie la trayectoria que recorre el camino del pecador, desde su pecado de traición (pecado personal, moral y político), pasando por el remordimiento como reacción y la desesperación como estado psicológico incontrolable (razón/sinrazón), hasta llegar, como colofón de ese itinerario desviado, al castigo erróneo de la autopunición, pretendiendo suplantar la justicia divina. El recorrido punible que había marcado el vector de ese camino neutralizaba cualquier posibilidad de comprensión o admiración, como la que se podría haber producido ante el gesto digno del suicidio trágico de Catón, o la caída voluntaria y apasionada de Dido o Hero. Otro tema sería el de la ironía o la posible comicidad en torno a algunos de estos episodios. Pero hay que ir con mucho tiento y conocer muy bien el alcance de la burla, el humor o la parodia en el mundo medieval para poder captar lo que hay de serio o cómico en las intertextualidades con las que nos enfrentamos, teniendo en cuenta que la figura de Judas estaba sometida ya a todo clase de tratamientos burlescos, incluso bufonescos, como hemos tenido ocasión de ir comentando. 
El significado de las muertes lamentables y funestas de los cinco personajes de La Celestina - los amantes, los criados y la propia alcahueta- es un tema o un conjunto de temas revestido de harta complejidad, que ha sido tratado en bloque o de manera individualizada, desde muy distintas perspectivas, de las que da cuenta la enorme bibliografía existente. A la hora de relacionarlas específicamente con la muerte (o muertes) de Judas, como hemos intentando hacer en este artículo, todas estas muertes se podrían amparar bajo el concepto de la cupitidas, es decir de la codicia previa demostrada por cada personaje y supuestamente causante de su muerte, desde un punto de vista moral, providencialista o teleológico. ${ }^{83}$

Desesperación y muerte, trastorno sicológico y crimen, falta grave - de imposible remisión-y castigo..., todo se concentra en la denuncia más severa de ese pecado execrable, resuelto en Judas como suicidio o como caída atroz, y en Pármeno como salto prácticamente suicida. Salto al que le conduce una trayectoria vital fatalmente condicionada desde el periplo y muerte de su propia madre Claudina. Un camino de errores, como los de Judas, incomprensibles, irreparables e imperdonables.

83.- Mientras que Calisto y Melibea pagan su cupitidas _ amorosa o sexual_ con sendas muertes, totalmente diferentes, aunque terribles en ambos casos, Celestina, Sempronio y Pármeno pagan las suyas — cupiditas materiales - de igual modo, terrible y letalmente, con no menos dramáticos y pavorosos finales. Sin embargo, de estos cinco personajes es especialmente Pármeno quien habrá experimentado antes de morir una transformación más radical en esa cupiditas material, que revela una trasformación ética total, desde la lealtad a la traición. Y por ello hemos enfocado principalmente sobre él nuestro interés, puesto que es, entre todos, quien sufre una metamorfosis más radical - la que conduce de la lealtad a la codicia, y de la codicia (cupiditas) a la muerte- y más cercana a la trayectoria legendaria de Judas, el discípulo perdido. Sin embargo, pienso que la sombra de Judas es más difusa y afecta, si bien más indirectamente, a los otros personajes «caídos» en la obra. Sin una exacerbación del deseo incontrolado, sin una extremosidad hasta la desmesura y el pecado de sus comportamientos codiciosos no se podrían haber dado esas cinco muertes, todas ellas excesivas, todas deshonrosas e infamantes. 


\section{Bibliografía}

Alvar, Carlos, Constance CarTa y Sarah Finci (2011), «El retrato de Esopo en los Isopetes incunables: imagen y texto", Revista de Filología Española, 91, 2, pp. 233-260.

Álvarez Moreno, Raúl (2017), «Notas a la ilustración de un duelo: el suicidio de Melibea en los grabados antiguos de Celestina», eHumanista, 35, pp. 311-331.

Andrés, Ramón (2003), Historia del suicidio en Occidente, Barcelona, Península. Arellano, Ignacio (2015), "Judas, mito y personaje en el teatro del Siglo de Oro», Neophilologus, 99, pp. 47-62.

Ayerbe-Chaux, Reinaldo (1978), "La triple tentación de Melibea», Celestinesca, 2.2, pp. 3-12.

Baldó Alcoz, Julia (2007), "Por la quoal cosa es dapnado. Suicidio y muerte accidental en la Navarra bajomedieval», Anuario de Estudios Medievales, 37/1, pp. 27-69.

Baum, Paull Franklin (1916a), "The Mediæval Legend of Judas Iscariot», PMLA, 31, 3, pp. 481-632.

- (1916b), "The English Ballad of Judas Iscariot», PMLA, 31, 2, pp. 181-189.

Beltrán, Rafael (1997), "La adaptación histórica de las glosas del marqués de Santillana a sus Proverbios en la Suma de virtuoso deseo", en Proceedings of the Eighth Coloquium, Queen Mary and Westield College Medieval Hispanic Research Seminar, ed. Andrew M. Beresford y Alan Deyermond, Londres, Queen Mary and Westield College, pp. 49-60.

- (2014), «Dibujos didácticos y memoria de la Antigüedad romana: las glosas de los Proverbios del Marqués de Santillana ilustradas en la Suma de virtuoso deseo», Troianalexandrina, 14, pp. 91-142.

Bergman, Ted L. (2012), "La Celestina and the Popularization of Graphic Criminal Violence», Celestinesca, 36, pp. 47-70.

Bernaschina Schürmann, Vicente (2010), "Las políticas de la amistad en La Celestina: el caso de Pármeno", Celestinesca, 34, pp. 9-28.

Bettini, Maurizio \& Giulio Guidorizzi (2008), El mito de Edipo: imágenes y relatos de Grecia a nuestros días, Madrid, Akal.

BizzArri, Hugo Óscar, ed. (2001), Castigos del rey don Sancho IV, Frankfurt-Madrid, Vervuert-Iberoamericana.

- (2002), "Del texto a la imagen: representaciones iconográficas de la realeza en un manuscrito de los Castigos del rey don Sancho IV (Ms. BN Madrid 3395)», Incipit, 22, pp. 53-94.

Brown, Ron M. (2001), The Art of Suicide, Londres, Reaktion Books.

Cane, Anthony (2005), The Place of Judas Iscariot in Christology, Londres y Nueva York, Routledge. 
CAnet Vallés, José Luis (1999), «El impresor valenciano Juan Jofré», en Tragicomedia de Calisto y Melibea (Valencia, Juan Joffre, 1514), Ed. Nicasio Salvador Miguel, Valencia, Institució Alfons el Magnànim, pp. 39-52.

CAnet Vallés, José Luis (2016), "Reflexiones sobre el libro ilustrado del impresor Fadrique Biel de Basilea», Revista de poética medieval, 30, pp. 81-104.

— - ed. (2020), Ediciones de la Comedia y la Tragicomedia de Calisto y Melibea: <https://parnaseo.uv.es/celestinesca.htm>.

Carmona Ruiz, Fernando (2007), "La recepción de La Celestina en Alemania en el siglo XVI», Tesis doctoral, Friburgo, Universität Freiburg.

- (2012), "La cuestión iconográfica de La Celestina y el legado de Hans Weiditz", eHumanista, 19, pp. 20-78.

CiviL, Pierre (2017), «Grabados celestinescos. La ilustración de un 'género' literario en la primera mitad del siglo XVI", en La escritura inacabada. Continuaciones literarias y creación en España. Siglos XII a XVII, eds. David Alvarez Roblin y Olivier Biaggini, Madrid, Casa de Velázquez, pp. 85-101.

Coffey, Heather (2013), "Encountering the Body of Muhammad: Intersections between Mi'raj Narratives, the Shaqg al-Sadr, and the Divina Commedia in the Age before Print", en Constructing the Image of $\mathrm{Mu}$ hammad in Europe, ed. Avinoam Shalem, Berlín-Boston, De Gruyter, pp. 33-86.

Cull, John, T. (2010), "A Possible Influence on the Burgos 1499 Celestina Illustrations: The German 1486 Translation of Terence's Eunuchus», La corónica, 38.2, pp. 137-60.

De SaS van Damme, Astrid (2013), «El amarillo en la Baja Edad Media. Color de traidores, herejes y repudiados», Estudios Medievales Hispánicos, 2, pp. 241-276.

Dickenson, Elizabeth G. y James M. Boyden (2004), "Ambivalence Toward Suicide in Golden Age Spain", en From Sin to Insanity: Suicide in Early Modern Europe, Jeffrey R. Watt, Ithaca, Cornell University Press, pp. 100-115.

Fernández Rivera, Enrique (2011), «La caída de Calisto en las primeras ediciones ilustradas de La Celestina», eHumanista, 19, pp. 137-156.

- (2013), «Influencias de la iconografia cristiana en las ilustraciones tempranas de La Celestina», en Two Spanish Masterpieces. A Celebration of the Life and Work of María Rosa Lida de Malkiel, ed. Pablo Ancos y Ivy A. Corfis, Nueva York, Hispanic Seminary of Medieval Studies, pp. 175-195.

FouCAULT, Michel (1976), Vigilar y castigar. Nacimiento de la prisión, Madrid, Siglo XXI.

García de Diego, Pilar (1973), "Catálogo de pliegos de cordel», Revista de Dialectologia y Tradiciones Populares, 29, 3-4, pp. 473-516.

GarCía SALA, Iván (2002), «El otro seno de Abraham: reflexiones acerca de una imagen escatológica», Erytheia, 23, pp. 119-143.

GarCía-Dussán, Éder (2019), «El caso del Festival del Burro en San Antero (Córdoba): parodia y redención social», Folios, 49, pp. 107-122. 
Gillet, Joseph E. (1925), «Traces of the Judas Legend in Spain», Revue Hispanique, 65, pp. 316-341.

Grifrin, Clive (2001), "Celestina's Illustrations», Bulletin of Hispanic Studies, 78, pp. 59-79.

Grimalt, Josep A. (2004), La figura de Judes a la literatura. Notes per a un estudi sobre hipertextualitat, Palma de Mallorca, Pastoral Universitària.

Haro, Marta (2012), «Proyecto iconográfico del códice miniado de los Castigos de Sancho IV (BNE, ms. 3995)", en Estudios de literatura medieval. 25 Años de la Asociación Hispánica de Literatura Medieval, eds. Antonia Martínez Pérez y Ana Luisa Baquero Escudero, Murcia, pp. 75-92.

- (2014), La iconografía del poder real: el códice miniado de los "Castigos de Sancho IV», Alcalá de Henares, Universidad de Alcalá.

Heugas, Pierre (1973), "La Célestine» et sa descendence directe, Institut d'Études Ibériques et Ibéro-américaines, Burdeos, Bière.

Heusch, Carlos (2000), "Las desviaciones de Pármeno o la caída de un ángel», Celestinesca, 26, pp. 29-44.

IgLESIAS, Yolanda (2015), «Implicaciones legales de las seis muertes en $\mathrm{La}$ Celestina: un acercamiento histórico-literario", Romance Quarterly, 62, 2, pp. 59-70.

- (2016), «Representación del delito social en La Celestina a través de su iconografía más temprana: 1499 y 1514», Revista Canadiense de Estudios Hispánicos, 41, pp. 243-272.

Jiménez Ruz, Ana Milagros (2020), «La primera portada celestinesca sevillana: estudio de una parodia iconográfica e iconológica», en Enrique Fernández y Amaranta Saguar (ed.), Videoactas del I Congreso del CELPYC (4-5 de junio de 2020), Nueva York, CELPYC, vídeo 04: <https:// doi.org/10.47537/celpyc2020.04>.

KovÁcs, Lenke (2008), «La mort del traïdor Judes com a antítesi de la mort redemptora de Crist en el teatre medieval i europeu», en Estudios sobre el teatro medieval, ed. Josep Lluís Sirera, Valencia, PUV, pp. 117-129.

LACARRA, Eukene (1990), Cómo leer "La Celestina», Madrid, Júcar.

- (2007), "La muerte irredenta de Melibea», en Proceedings of the International Symposium 1502-2002: Five Hundred Years of Fernando de Rojas' "Tragicomedia de Calisto y Melibea» (18-19 October 2002, Department of Spanish and Portuguese, Indiana University, Bloomington). ed. Juan Carlos Conde, Nueva York, Hispanic Seminary of Medieval Studies, pp. 173-208.

LaCARRA, María Jesús (2011), "La fortuna del Ysopete en España», en Actas del XIII Congreso Internacional de la Asociación Hispánica de Literatura Medieval, Valladolid, Univ. de Valladolid, pp. 105-133.

- (2020), "La Celestina», COMEDIC: Catálogo de obras medievales impresas en castellano hasta 1600. En línea: <https://comedic.unizar.es/ index/read/id/322>.

LAEUCHLI, Samuel (1953) «Origen's Interpretation of Judas Iscariot», Church History, 22, 4, pp. 253-268. 
Lafran, Anne (2007), «La mort de Judas Iscariote dans les Bibles moralisées du XIII ̀̀ siècle», Revue Mabillon, nouv. série, 18 (= t. 79), pp. 163-192.

Lida de Malkiel, María Rosa (1952), "El desenlace del Amadís primitivo", Romance Philology, 6, pp. 283-289.

- (1962), La originalidad artística de "La Celestina», Buenos Aires, Eudeba. (1974), Dido en la literatura española: su retrato y defensa, Londres, Tamesis.

López-Ríos, Santiago (2005), «Pon tú en cobro este cuerpo que allá baja: Melibea y la muerte infamante en La Celestina», en Dejad hablar a los textos. Homenaje a Francisco Márquez Villanueva, ed. Pedro M. Piñero, Sevilla, Universidad de Sevilla, pp. 309-326.

LoRIte CruZ, Pablo Jesús (2011), «La forma de representar a Judas Iscariote en la imaginería religiosa española», Revista de Claseshistoria, 225, pp. 1-16.

Marías Martínez, Clara (2013), «Remedios y desenlaces desesperados: el suicidio en las novelas cortas de Juan Pérez de Montalbán y María de Zayas y Sotomayor", en Los viajes de Pampinea: novella y novela española en los Siglos de Oro, eds. Isabel Colón et al., Madrid, Sial, pp. 259-282.

Matthies Baraibar, Silvia (2000), "La dama en la torre: doña Ximena y Melibea, dos manifestaciones de un símbolo en nuestra literatura medieval», en Actas del VIII Congreso Internacional de la Asociación Hispánica de Literatura Medieval, ed. Margarita Freixas et al., Santander, Consejería de Cultura del Gobierno de Cantabria, pp. 1289-1298.

McCullogh, Janice (1998), "Upside Down», en Encyclopedia of Comparative Iconography: Themes Depicted in Works of Art, ed. Helen E. Roberts, Chicago, Fitzroy Dearborn, pp. 875-881.

McGowan, Felicity Harley (2011), "Death is Swallowed Up in Victory Scenes of Death in Early Christian Art and the Emergence of Crucifixion Iconography", Cultural Studies Review, 17, pp. 101-24.

Mier Pérez, Laura (2016), «Melibea, Plácida y Serafina: tres muertes violentas en el primer teatro clásico", Celestinesca, 40, pp. 117-134.

MinoIs, George (1999), History of Suicide: Voluntary Death in Western Culture, Baltimore y Londres, John Hopkins University Press.

Moreno, Charo (2007), "Imágenes de Dido y Eneas en los Castigos del rey don Sancho IV (ms. 3995 BNE, s. XV)", E-Spania, 3: <https://e-spania. revues.org/297>.

Murray, Alexander (2000), Suicide in the Middle Ages, Oxford, Oxford University Press, 2 vols.

Pastoureau, Michel (2006), «El hombre pelirrojo. Iconografía medieval de Judas», en Una historia simbólica de la Edad Media occidental, Buenos Aires, Katz, pp. 219-234.

Perea Yébenes, Sabino (2006), «La mención a Judas Iscariota en epitafios latinos cristianos de la Hispania visigoda y bizantina: el delito sepulcral y la condena mágica», Myrtia, 21, pp. 235-276. 
Poza YagüE, Marta (2010), "La avaricia», Revista Digital de Iconografía Medieval, 4, pp. 9-19.

Prat Ferrer, Juan José (2006), "El parricida y el incestuoso involuntarios en el folklore occidental», Revista de folklore, 306, pp. 183-199.

Propp, Vladimir (1982 [versión orig., 1944]), Edipo a la luz del folklore, Madrid, Fundamentos, $3^{\mathrm{a}}$ ed.

RYAN, Maurice, "Creating Judas Iscariot: critical questions for presenting the betrayer of Jesus», Journal of Religious Education, 67, 3, pp. 223-237.

Robson, Janet Eileen (2001), Speculum Imperfectionis. The Image of Judas in Late Medieval Italy, Tesis doctoral, Londres, Univ. de Londres, 2 vols.

Rodríguez BarRal, Paulino (2008), «El recurso al judío deicida: un punto de encuentro entre el drama y las artes visuales en la Valencia de la Edad Media final», en Estudios sobre el teatro medieval, ed. Josep Lluís Sirera, Valencia, PUV, pp. 157-174.

RojAS, Fernando de (y "antiguo autor») (2011), La Celestina. Tragicomedia de Calisto y Melibea, ed. F. J. Lobera, G. Serés, P. Díaz-Mas, C. Mota e I. Ruiz Arzálluz, y F. Rico, Barcelona, Galaxia Gutenberg / Círculo de Lectores. [ = LC]

Romero Lucas, Diego, ed. (2001), La vida y fábulas del Ysopo [Valencia, Juan Jofré, 1520], en Lemir, 5, s. p.: <http://parnaseo.uv.es/lemir/textos/Ysopo/indexpar.htm>.

Romero, Loreto (2020), «El cuerpo en pedazos: Violencia, erotismo y fragmentación en las ilustraciones de la Tragicomedia de Calisto y Melibea», en Enrique Fernández y Amaranta Saguar (ed.), Videoactas del I Congreso del CELPYC (4-5 de junio de 2020), Nueva York, CELPYC, vídeo 10: $<$ https://doi.org/10.47537/celpyc2020.10>.

RYAN, Maurice (2019), "Creating Judas Iscariot: critical questions for presenting the betrayer of Jesus", Journal of Religious Education, 1, 3 [online] <https://doi.org/10.1007/s40839-019-00089-z>.

SAARI, A. M. H. (2006), The Many Deaths of Judas Iscariot. A Meditation on Suicide, Londres y Nueva York, Routledge.

Saguar García, Amaranta (2015), "The Concept of Imago Agens in Celestina: Text and Image», Celestinesca, 39, pp. 247-274.

(2017a), «Las ilustraciones de las traducciones alemanas de Celestina: Hans Weiditz y la Tragicomedia de Calisto y Melibea», Celestinesca, 41, pp. 139-152.

- (2017b), «Las imagines agentes de Celestina (II). La tradición iconográfica", en En Doiro antr'o Porto e Gaia. Estudos de Literatura Medieval Ibérica, coord. José Carlos Ribeiro Miranda, ed. lit. Rafaela da Câmara Silva, Oporto, Estratégias Creativas, pp. 885-892.

- (2020), «¿Un programa iconográfico original? Modelos alemanes para los tacos de la edición Zaragoza, en la oficina de Jorge Coci a costa de Pedro Bernuz y Bartolomé de Nájera, 17 de junio de 1545, de Celestina», en Enrique Fernández y Amaranta Saguar (ed.), Videoactas del 
I Congreso del CELPYC (4-5 de junio de 2020), Nueva York, CELPYC, vídeo 11: <https://doi.org/10.47537/celpyc2020.11>.

SANMARTín BASTIDA, Rebeca (2005), "Sobre el teatro de la muerte en $\mathrm{La}$ Celestina: el cuerpo 'hecho pedazos' y la ambigüedad macabra", eHumanista, 5, pp. 113-125.

Schmit, Jean-Claude (1976), "Le suicide au Moyen Âge», Annales, 31, 1 (= Autour de la mort), pp. 3-28.

Schnitzler, Norbert (2000), «Judas' Death: Some Remarks Concerning the Iconography of Suicide in the Middle Ages», The Medieval History Journal, 3, 1, pp. 104-119.

Snow, Joseph (1987), «La iconografía de tres Celestinas tempranas (Burgos, 1499; Sevilla, 1518; Valencia, 1514): unas observaciones», Dicenda, 6, pp. 255-277.

- (1989), “¿Con qué pagaré esto?’: The Life and Death of Pármeno», en The Age of the Catholic monarchs, 1474-1516: Literary Studies in Memory of Keith Whinnom, ed. Alan Deyermond and Ian Macpherson, Liverpool, Liverpool UP, pp. 185-192.

(2005), «Imágenes de la lectura / lectura de las imágenes: el caso de la Comedia burgalesa impresa por Fadrique de Basilea», en Filologia dei Testi a Stampa, ed. Patrizia Botta, Modena, Mucchi, pp. 111-129.

- (2013), "Confederación e ironía: crónica de una muerte anunciada (Celestina, autos I-XII)», Celestinesca, 37, pp. 119-138.

Stamm, James R. (1977), "El tesoro de Pármeno», en La Celestina y su contorno social, Actas del I Congreso Internacional sobre "La Celestina», ed. Manuel Criado de Val, Barcelona, Borrás, pp. 185-191.

ToldrÀ I Vilardell, Albet (2018), "Judes-Èdip en l'edat mitjana», Scripta, 12 , pp. $143-151$.

Tozer, Amanda J. A. (2003), "La identidad masculina en Celestina: la emasculación de Pármeno", Celestinesca, 27, pp. 149-164.

- (2004), "Tristán, Sosia and Centurio as Burlesque Figures», La corónica, 32, 2, pp. 151-170.

Treusdell, William D. (1975), «Pármeno's Triple Temptation: Celestina, Act I», Hispania, 58.2, pp. 267-276.

Weber, Annette (2002), «The Hanged Judas of Freiburg Cathedral: Sources and Interpretations», en Imagining the Self, Imagining the Other: Visual Representation and Jewish-Christian Dynamics in the Middle Ages and Early Modern Period, ed. Eva Frojmovic, Leiden-Boston-Köln, Brill, pp. 165-188.

Zambrano, Pablo Luis (2006), "Literatura y suicidio: breve historia del debate», en sus Estudios sobre literatura y suicidio, Sevilla, Alfar, pp. 13-42. 
